\title{
After the ice: Lateglacial and Holocene landforms and landscape evolution in Scotland
}

\begin{tabular}{|r|l|}
\hline Journal: & $\begin{array}{l}\text { Earth and Environmental Science Transactions of the Royal Society of } \\
\text { Edinburgh }\end{array}$ \\
\hline Manuscript ID & TRE-2017-0023.R1 \\
\hline Manuscript Type: & The Quaternary of Scotland \\
\hline Date Submitted by the Author: & n/a \\
\hline Complete List of Authors: & $\begin{array}{l}\text { Ballantyne, Colin; University of St Andrews, Geography and Sustainable } \\
\text { Development }\end{array}$ \\
\hline Keywords: & $\begin{array}{l}\text { alluvial fan, debris flow, floodplains, paraglacial, periglacial, permafrost, } \\
\text { postglacial, rock-slope failure }\end{array}$ \\
\hline
\end{tabular}

SCHOLARONE ${ }^{m}$

Manuscripts 


\section{After the ice: Lateglacial and Holocene landforms and landscape evolution in Scotland}

\section{Colin K. Ballantyne}

School of Geography and Sustainable Development, University of St Andrews, St Andrews KY16 9AL, UK.

Running head: Lateglacial and Holocene landforms in Scotland 


\section{ABSTRACT:}

During Lateglacial cold periods, permafrost developed throughout Scotland, sediment-mantled slopes were extensively modified by solifluction and other forms of periglacial mass movement, large-scale sorted patterned ground formed on plateaux, and enhanced rockfall resulted in talus accumulation below cliffs. Most rock-slope failures occurred within five millennia following icesheet deglaciation, with many probably triggered by uplift-induced earthquakes; numerous debris-free scarps represent sites where Lateglacial rockslide debris was excavated by glaciers during the Younger Dryas Stade $(\sim 12.9-11.7 \mathrm{ka})$. Sandar and outwash fans deposited by glacial rivers during ice-sheet retreat were incised to form high-level terraces. Under the cool temperate but relatively stable climate of the Holocene, solifluction and patterned ground formation continued to operate on high ground, though accumulation of high-level aeolian deposits on most mountains was terminated by erosion during the Little Ice Age. Drift-mantled slopes and talus slopes have been extensively eroded by translational failures and debris flows, the latter depositing debris cones on upland valley floors. The incidence of Holocene rockslides has been much lower than during the Lateglacial period. Dating of alluvial deposits and low Holocene terraces suggests no consistent pattern of Holocene floodplain evolution: incision has apparently dominated in the Highlands, aggradation in the lowlands, and floodplains in the Southern Uplands have asynchronous histories of incision and aggradation. Studies of floodplain behaviour over the past 200-300 years suggest that though major floods rework the floodplains of braided and piedmont rivers, there is no tendency towards net floodplain aggradation or incision. Most valley-side alluvial fans accumulated episodically in the last 4000 years, many in response to lowering of hillslope stability by woodland clearance. For many postglacial landsystems, disentangling the effects of declining paraglacial sediment supply, climate change and local influences (extreme rainstorm events or anthropogenic impacts) remains challenging.

KEY WORDS: alluvial fan; debris flow; floodplain; paraglacial; periglacial; permafrost; postglacial; rock-slope failure; talus; terraces. 
The landforms and landscapes of Scotland are commonly perceived as being dominated by the legacy of successive Pleistocene glaciations. In the Highlands, Hebrides and Southern Uplands, glacier ice has sculpted the landscape into cliffs, corries, arêtes, glacial troughs and rock basins. Lowland areas underlain by resistant bedrock are characterised by ice-scoured topography, and those underlain by sedimentary rocks are often buried under a thick mantle of glacigenic deposits. Since the last Pleistocene glaciers vanished from Scotland, however, the Scottish landscape has been subject to modification by a wide range of postglacial processes: entire mountainsides have shifted or collapsed, glacigenic sediments have been extensively reworked by landslides and debris flows; rivers have incised and migrated across their floodplains; frost action and strong winds have modified high plateaux; and the coastal zone has responded to changes in sea-level and sediment flux.

This review synthesises current understanding of the postglacial evolution of the Scottish landscape. Following a brief introduction to the nature and chronology of postglacial environmental changes in Scotland and the role of paraglacial landscape modification, current understanding of landscape evolution under the striking environmental changes of the Lateglacial period (from the time of ice-sheet deglaciation until $\sim 11.7 \mathrm{ka}$ ) is outlined, followed by an assessment of ways in which the landforms and landscapes of Scotland have evolved under the comparatively climatically stable environment of the Holocene ( 11.7 ka to the present). Postglacial changes in sea level and coastal configuration are reviewed in this issue by Smith et al. (2018), and are considered here only where relevant to the understanding of river systems. Key locations mentioned in the text are shown in Figure 1.

\section{Chronology of deglaciation and postglacial environmental change}

Throughout this review ages are expressed as either thousands of years (ka) or years (a) before present. Uncalibrated radiocarbon ages are identified as ${ }^{14} \mathrm{C}$ a $\mathrm{BP}$ or ${ }^{14} \mathrm{C} \mathrm{ka} \mathrm{BP}$, where 'BP' ('before present') refers by convention to $\mathrm{AD} 1950$, and calibrated radiocarbon ages as cal ${ }^{14} \mathrm{C}$ a or cal ${ }^{14} \mathrm{C}$ ka referenced to $\mathrm{AD} 2000$. For consistency, radiocarbon ages have been calibrated with the CALIB 7.10 calibration software (Stuiver et al. 2016), using the IntCal13 dataset (Reimer et al. 2013). Terrestrial cosmogenic nuclide (TCN) exposure ages cited here assume a post-exposure erosion rate of $1 \mathrm{~mm} \mathrm{ka}^{-1}$; assumption of zero erosion reduces ${ }^{10} \mathrm{Be}$ exposure ages by $\sim 1 \%$, and assumption of an erosion rate of $2 \mathrm{~mm} \mathrm{ka}^{-1}$ increased ages by $\sim 1 \%$. ${ }^{10} \mathrm{Be}$ ages have been recalibrated using the Loch Lomond production rate (Fabel et al. 2012), using the Lm scaling of the CRONUS-Earth online calculator (Balco et al. 2008). Cited uncertainties for exposure ages are total (external) uncertainties at $\pm 1 \sigma$.

The last ice-sheet glaciation of Scotland occurred during the Dimlington Stade ( 31$14.7 \mathrm{ka}$ ) of the Late Devensian (= Late Weichselian) substage. At its maximum extent, the last ice sheet buried all Scottish mountains, extended far westward onto the Atlantic shelf, and to the east was confluent with the Fennoscandian Ice Sheet in the North Sea Basin (Bradwell et al. 2008; Hubbard et al. 2009; Ballantyne 2010a; Clark et al. 2012; Ballantyne \& Small 2018). During the Last (global) Glacial Maximum ( $\sim 27-19 \mathrm{ka})$, therefore, all of the present land area of Scotland (apart from the St Kilda archipelago) was buried under glacier ice, and the timeline of postglacial landscape evolution begins when the land surface emerged from under the retreating ice-sheet 
(Fig 2). The term 'Lateglacial' is here used to denote the period between ice-sheet deglaciation and the onset of the Holocene at $\sim 11.7 \mathrm{ka}$.

Ice-sheet deglaciation across Scotland was spatially diachronous, spanning the interval 21-14 ka. By $\sim 17 \mathrm{ka}$ most of Scotland was still ice-covered, apart from parts of the Outer Hebrides, the extreme NW mainland, Caithness and the eastern seaboard. By $\sim 16$ ka the Solway lowlands, Orkney and Shetland were deglaciated, the ice margin lay amongst the Inner Hebrides and along the $\mathrm{W}$ coast, nunataks had emerged from under the ice in Wester Ross, the ice margin had retreated to the Cairngorms and the sea had invaded the Forth and Tay estuaries. By $\sim 15 \mathrm{ka}$ most of the Southern Uplands, Midland Valley and NW Scotland and the Eastern Grampians were ice-free and a residual ice cap or icefield occupied the western Highlands (Ballantyne \& Small 2018).

Before $\sim 14.7 \mathrm{ka}$ terrain vacated by the retreating ice sheet was exposed to severe periglacial conditions, with evidence for the development of permafrost to present sea level (Fig. 2). Analysis of subfossil coleopteran assemblages in Lateglacial sediments (Atkinson et al. 1987) has suggested that during the final part of the Dimlington Stade mean annual air temperatures were within the range $-5^{\circ} \mathrm{C}$ to $-10^{\circ} \mathrm{C}$, with mean January temperatures of $-20^{\circ} \mathrm{C}$ to $-25^{\circ} \mathrm{C}$. Around $14.7 \mathrm{ka}$, strengthening of Atlantic meridional overturning circulation returned much warmer surface waters to the coasts around Scotland, causing a rapid rise in summer temperatures (Brooks \& Birks 2000; Brooks et al. 2012) and ushering in the cool temperate climate of the Lateglacial Interstade (14.7-12.9 ka; Fig. 2).

There is debate as to whether remnants of the shrinking ice sheet persisted in favourable locations during the Lateglacial Interstade, but if so they must have been restricted to some high plateaux and corries (Hubbard et al. 2009; Finlayson et al. 2011), and it is reasonable to assume that all or almost all low ground was ice-free by $\sim 14$ ka (Ballantyne \& Stone 2012; Ballantyne \& Small 2018). Subsequent cooling resulted in a readvance of glacier ice, the Loch Lomond Readvance (LLR), which reached its maximum extent during the Loch Lomond Stade of $\sim 12.9-$ $11.7 \mathrm{ka}$, the Scottish equivalent of the Younger Dryas Stade (YDS). During the thermal nadir of the YDS, mean July sea-level temperatures in Scotland were $\sim 7^{\circ} \mathrm{C}$ or slightly lower (Brooks et al. 2012) and (with lower confidence) mean January temperatures were probably about $-20^{\circ} \mathrm{C}$ (Atkinson et al. 1987), implying mean annual temperatures of roughly $-6^{\circ} \mathrm{C}$, though slightly colder conditions probably prevailed in northern Scotland. Under these conditions a substantial ice cap or icefield reoccupied much of the Western Highlands, flanked by smaller peripheral icefields in Skye, Mull, the northern Highlands, Monadhliath and Eastern Grampians, and numerous smaller corrie and valley glaciers; small glaciers also developed in the Tweedsmuir and Galloway Hills of the Southern Uplands (Golledge, 2010; Fig. 3). Most LLR glaciers probably reached their maximum extent and began to retreat by $\sim 12.5-12.2 \mathrm{ka}$ (Golledge et al. 2008; Ballantyne 2012; Bromley et al. 2014), though there is evidence that some did not achieve their maximum extent until near the end of the YDS (MacLeod et al. 2011) and that glacier ice may have persisted in some areas as late as $\sim 11.5 \mathrm{ka}$ (Small \& Fabel 2016). The timeline for postglacial landscape evolution within the limits of the LLR is therefore much shorter $(\sim 12.5-$ $11.5 \mathrm{ka}$ to the present) than that for terrain outside these limits ( $21-14 \mathrm{ka}$ to the present). An additional implication is that areas outside the limits of the LLR experienced renewed periglacial (permafrost) conditions during the $\sim 1.2 \mathrm{ka}$ of the YDS (Fig. 2 and section 3.1.1 below). 
The Holocene was initiated at $\sim 11.7 \mathrm{ka}$ when resumption or strengthening of Atlantic meridional circulation returned warm oceanic waters to the latitude of Scotland, causing rapid climate warming (Atkinson et al. 1987; Brooks et al. 2012; Fig. 2) and disappearance of residual LLR glaciers. Temperate conditions similar to those of the present were established by $\sim 11.0 \mathrm{ka}$. Much of the early Holocene was characterised by relatively warm summers (the Holocene thermal maximum, or 'climatic optimum') followed by a very slight cooling trend over the past 5000 years during which 'average' temperatures oscillated by up to $\pm 2{ }^{\circ} \mathrm{C}$ over decades or longer (Briffa \& Atkinson 1997; Rydval et al. 2017). In the northern hemisphere, this overall pattern was interrupted by several brief cooling events centred around 9.2, 8.2, 6.3, 4.7, 2.7 and $1.5 \mathrm{ka}$ (Wanner et al. 2011), though the nature of climate change in Scotland at these times is uncertain. Multi-proxy evidence from peat bogs also indicates at least local shifts in wetness over the past five millennia (Blundell \& Barber 2005; Langdon \& Barber 2005). Apart possibly from the $8.2 \mathrm{ka}$ cooling event, the most severe period of Holocene cooling in Scotland was the 'Little Ice Age', a period of general climatic deterioration conventionally attributed to the 16th-19th centuries $\mathrm{AD}$, though cooling may have begun two or three centuries earlier (Matthews \& Briffa 2005; Wanner et al. 2011). Historical evidence shows that particular decades during the Little Ice Age were characterised by cool, wet summers, exceptional storminess and survival of perennial snowcover on high ground (e.g. Whittington 1985; Lamb 1991; Dawson 2009), though parts of E Scotland experienced mean annual precipitation lower than now (Thom \& Ledger 1976). Summer temperature reconstructions based on tree-ring evidence suggest that within the period AD 1580-1810, summer temperatures in the northern Cairngorms averaged about $1{ }^{\circ} \mathrm{C}$ lower than the 1961-1990 average (Rydval et al. 2017). Some authors have argued that niche glaciers may have formed in the Cairngorms at this time (Harrison et al. 2014; Kirkbride et al. 2014), but the dating and modelling evidence on which their arguments are based appear inconclusive; the wide range of reported TCN ages used to support this interpretation could equally be interpreted in terms of progressive disinterment of boulders as the moraines in which they were embedded were slowly eroded by snow avalanches.

\section{Paraglacial landscape modification}

The downwastage and retreat of glacier ice often results in exposure of metastable, glaciallyconditioned sediment sources that are subsequently released and reworked by various processes over a wide range of timescales (Ballantyne 2002a, 2002b; Mercier 2011). Rock masses released from the weight of overlying glacier ice experience major changes in the state of stress, and propagation of stress-release joints precipitates failure in the form of rockfalls, rockslides, rock avalanches and large-scale slope deformation (McColl 2012). Glacigenic sediments on slopes may be reworked by landslides, debris flows, snow avalanches and mountain torrents. Valleyfloor glacigenic sediments are eroded, transported and deposited by rivers, forming alluvial fans and valley fills, or deltas and bottom sediments in lakes and fjords. The paraglacial system may be envisaged as an interrupted sediment cascade (Fig. 4) in which non-renewable sediment sources (unstable rockwalls, drift-mantled slopes and valley-floor glacigenic sediments) are released or entrained by a range of processes towards terminal sediment sinks. However, sourceto-sink transport is often interrupted by sediment redeposition in paraglacial sediment stores such as talus accumulations, debris cones, alluvial fans, valley fills and river terraces. Some sediment 
stores continue to accumulate over several millennia, but others experience degradation within a few centuries or millennia (Ballantyne 2002a, 2013a).

Ballantyne (2008) has explored the implications of paraglacial landscape modification for Holocene landform evolution in the Scottish Highlands. The most important conclusions are (1) that sediment transfer processes tended to be greatly enhanced in the immediate aftermath of deglaciation, and to decline thereafter; and (2) that paraglacial sediment stores experienced an eventual change from net accumulation to net erosion, reflecting the non-renewable nature of paraglacial sediment sources (Ballantyne 2003a). This latter concept explains why many postglacial landforms in Scotland (talus accumulations, debris cones, and alluvial fans) are essentially relict features where erosion or incision has replaced deposition as the dominant mode of geomorphic activity. It also explains why many postglacial floodplains appear to have experienced initial aggradation succeeded by river incision and terrace development, though other influences (exceptional storm events, changes in base level, woodland clearance and land-use changes) are superimposed on the general model of paraglacial landform evolution (Lewin et al. 2005). Ballantyne (2008) also emphasised that some aspects of postglacial landscape evolution are independent of prior glacial conditioning.

\section{Lateglacial landscape evolution}

\subsection{Lateglacial periglaciation in lowland Scotland}

3.1.1. Permafrost. There is abundant evidence for the development of Lateglacial permafrost in Scotland, mainly in the form of ice-wedge pseudomorphs (ice-wedge casts) and polygonal crop marks. Both represent thermal contraction crack networks developed in former permafrost. Ice-wedge pseudomorphs form through thaw of ice wedges and infill of the resultant void by adjacent and overlying material, producing $\mathrm{V}$-shaped structures that interrupt the bedding of the host sediment. Polygonal crop marks, generally 5-50 m wide, represent differences in the moisture retention properties of soil infilling the polygonal pattern of troughs above ice-wedge pseudomorphs compared with those of adjacent ground, so that plant growth in troughs is enhanced or retarded, and the ghost of the original polygonal thermal contraction crack network remains visible on aerial or satellite images.

The most comprehensive inventory of wedge structures in Scotland remains that of Galloway (1961), updated by Ballantyne (1997). These are typically 1.5-3.0 m long, dimensions consistent with the former growth of epigenetic ice wedges that formed within pre-existing permafrozen sediment, though Aitken (1998) has attributed some exceptionally large wedge structures in outwash deposits to melt-out of buried glacier ice. The majority of reported icewedge pseudomorphs are preserved in stratified glacifluvial sands and gravels, probably because wedge structures in till or fine-grained sediments are often destroyed during thaw, and hence have limited preservation potential (Murton \& French 1993a). Some structures recorded as icewedge pseudomorphs may actually represent sand wedges (in which the original crack infill consisted of windblown sand rather than ice) or former composite wedges, where the original infill comprised both ice veins and sand (Murton 2013). These structures are also diagnostic of thermal contraction cracking of former permafrost, but imply either regional aridity and sparse vegetation cover, or a nearby source of aeolian sand such as an unvegetated braidplain. 
Although wedge structures $>1 \mathrm{~m}$ long and thermal contraction polygons $>5 \mathrm{~m}$ wide indicate former extensive (usually continuous) permafrost, severe winter cold and rapid winter cooling, there is debate regarding their relationship to mean annual air temperature (MAAT; $c f$. Murton \& Kolstrup 2003; Plug \& Werner 2008; Murton 2013). Thermal contraction cracking of permafrost has been reported from areas where MAATs are as high as $-3.5^{\circ} \mathrm{C}$, but thermal contraction cracking in sands and gravels is generally believed to occur where MAATs are below $-6^{\circ} \mathrm{C}$ to $-8^{\circ} \mathrm{C}$ (Huijzer \& Vandenberghe 1998), though this 'warm side' estimate should be regarded as indicative rather than definitive (Ballantyne 2017).

All convincing recorded examples of ice-wedge pseudomorphs and relict thermal contraction crack polygons in Scotland occur outside the limits of the LLR, mainly in lowland areas of Buchan and the Midland Valley (Fig. 3). This distribution implies that widespread permafrost developed in these areas either on terrain vacated by the retreat of the last ice sheet during the late Dimlington Stade (roughly 17-14.7 ka) or during the YDS ( 12.9-11.7 ka). It is possible that thermal contraction crack networks developed during the former period were reactivated during the latter, but no evidence of rejuvenated wedge structures has been reported. Some authors, notably Rose (1975) and Gemmell \& Ralston (1984) have argued for ice-wedge formation during the YDS, but the field evidence on which their arguments are based is equivocal (Ballantyne \& Harris 1994, p. 288). Periglacial evidence from elsewhere in the British Isles and Western Europe nevertheless indicates that permafrost probably developed down to sea level in Scotland both in the wake of the retreating ice sheet and again during the YDS (Isarin 1997; Ballantyne 2017). There is evidence for YDS ice-wedge formation as far south as Lincolnshire (Worsley 2014), and in southern England active-layer detachment deposits overlie organic deposits of Lateglacial Interstadial age, implying at least discontinuous permafrost during the YDS (Chandler et al. 1976; Spink 1991; Hutchinson 2010).

The presence of Lateglacial permafrost in Scotland has also been inferred from the presence of nearsurface involutions in sediments of Late Devensian age. Involutions take the form of perturbations within stratified sediments, or vertical interdigitation of two or more sediment layers with contrasting textural properties. Upward sediment movement is represented by diapiric and dyke-like structures, and downward sediment movement by synclinal and bulbous structures, or ball-and-pillow forms comprising upper unit sediment encased within a lower sediment unit. Most involutions represent load casting attributable to density inversion during thaw of ice-rich soils, though some authors have attributed their formation to differential seasonal frost penetration or cryohydrostatic pressures generated in freezing soil (Vandenberghe 2013). In Scotland, documented involutions have a distribution similar to that of ice-wedge pseudomorphs and polygons (Fig. 3), and have usually been interpreted as cryoturbation structures formed in the active layer above former permafrost during recurrent freezing and thawing of the ground (Ballantyne \& Harris 1994), implying that the depth of the involutions approximates the thickness of the former active layer. Although this is probably the case for involutions that terminate at a constant depth, involutions also develop during thaw of ice-rich permafrost (Murton \& French 1993b) and such thermokarst involutions may penetrate to much greater depths. The involutions documented in Scotland by Galloway (1961) and others reach depths of $0.8-1.8 \mathrm{~m}$, and it is likely that many are thermokarst involutions rather than cryoturbation structures. Caution is required in the interpretation of involutions as indicative of former permafrost, however, as small 
cryoturbations may development in seasonally-frozen ground lacking permafrost, and softsediment deformation structures may be produced by rapid loading of saturated sediments or by seismic activity (Ringrose 1989a).

The former presence of Lateglacial permafrost in lowland areas is also attested by the presence of indurated horizons (fragipans) in soils. In permafrost environments, translocated clay and silt particles accumulate at the base of the active layer and in the transient layer at the top of permafrost. There they become consolidated by recurrent freezing and thawing, forming a relatively dense impermeable layer, often with a platy structure (Van Vliet \& Langohr 1981). In Scotland, indurated layers occur in many freely-drained soils, typically at $0.4-0.6 \mathrm{~m}$ depth. They have sharp upper boundaries but diffuse lower ones; a platy structure is often evident near the top, but the indurated layer becomes more massive with depth. Although fragipans also develop in non-periglacial settings, it is likely that those in Scotland represent former Lateglacial permafrost, and that their depth approximates that of the former active layer (FitzPatrick 1956, 1969, 1987).

3.1.2. Periglacial mass movement in lowland areas. Throughout lowland Scotland, slopes mantled by frost-susceptible sediments (those in which ice lenses form during freezing) were affected by Lateglacial solifluction, the slow seasonal downslope movement of soil due to recurrent freezing and thawing of the active layer. Solifluction in permafrost areas has three components (Matsuoka 2001; Harris 2013): frost creep (heaving of soil normal to the slope during freezing, and settling of soil farther downslope during thaw), gelifluction (gravity-induced shear deformation of soil induced by high pore-water pressures during thaw) and plug-like deformation, which results from en masse movement of the active layer associated with thaw of ice-rich soil immediately above the permafrost table. The last operates only in areas of 'cold' permafrost, where seasonal freezing of the active layer occurs from the permafrost table upward as well as from the surface downward, resulting in the formation of segregation ice at the base of the active layer.

In much of lowland Scotland, Lateglacial solifluction has mainly affected till-mantled slopes, though solifluction of weathered rock debris to produce distinctive 'head' deposits is common in NE Scotland, particularly on the Buchan plateau (Merritt et al. 2003). Solifluction deposits often overlie glacifluvial gravels in meltwater channels, and soliflucted till deposits $>3 \mathrm{~m}$ thick have accumulated at slope-foot locations. Solifluction deposits are characterised by preferred downslope alignment of clasts, crude stratification and, more locally, intercalated seams of weathered bedrock material. In NE Scotland, where slope deposits are thin, downslope deformation of underlying rock strata is sometimes evident, and soliflucted material is underlain by a basal discontinuity (FitzPatrick 1987) that probably represents movement by plug-like deformation, implying that the underlying permafrost was 'cold' (below $-2{ }^{\circ} \mathrm{C}$ ) and continuous. Lateglacial solifluction deposits or soliflucted till both underlie and overlie organic deposits of Lateglacial Interstadial age, implying that solifluction affected lowland slopes during both the late Dimlington Stade and during the YDS. Excavations on the flanks of drumlins in the Glasgow area have revealed over $4 \mathrm{~m}$ of soliflucted till overlying Lateglacial Interstadial peat deposits (Dickson et al. 1976), and occurrences of soliflucted sediments overlying Lateglacial Interstadial organic sediments also occur in NE Scotland (Harkness \& Wilson 1979; Connell \& Hall 1987; Merritt et al. 2003). 
In areas of moderate relief, Lateglacial slope deposits have accumulated on valley floors as periglacial valley-fill deposits, notably in the Southern Uplands and Cheviot Hills. In broad valleys these form terraces 20-300 m wide, with steep frontal bluffs produced by river incision. Some consist of reworked till or regolith; others comprise in situ till overlain by reworked till and frost-weathered bedrock derived from adjacent slopes (Harrison 2002). Some are massive, others crudely stratified, and some are intercalated with or overlain by thin beds of slopewash gravels (Mitchell 2008). Such periglacial valley fills were initially attributed to downslope transport of till or regolith by Lateglacial solifluction over permafrost (Douglas \& Harrison 1987), and dating of such deposits in the Cheviots suggests that they mainly accumulated during the YDS (Harrison et al. 2010). Harrison (1996, 2002), however, has suggested that the thickness of valley fill in the Cheviots is incompatible with slow transport of sediment by solifluction, and proposed that they partly represent downslope reworking of valley-side drift by paraglacial debris flows. An alternative explanation, noted by Harrison (2002) is that active-layer failures may also have contributed to valley-fill accumulation. This appears plausible, particularly given the evidence for active-layer detachment failures in England during the YDS (Chandler et al. 1976; Spink 1991; Hutchinson 2010). Active-layer failures involve mobilization of the full depth of active layer over permafrost, and are triggered by rapid thaw of ice-rich soil at the base of the active layer, or of ice-rich sediment at the top of permafrost (Lewkowicz \& Harris 2005). They occur on low to moderate slopes as translational slides and as flowslides, where the sliding mass loses coherence and continues to move downslope as a viscous flow (Harris et al. 2008), sometimes extending several hundred metres beyond the slope foot over low gradient terrain (Lewkowicz 2007). Given the likelihood that lowland Scotland was underlain by 'cold' permafrost during the Lateglacial, it seems probable that active-layer failures contributed to the downslope movement of till and other slope deposits at this time, and that many thick slope-foot deposits hitherto attributed to Lateglacial solifluction accumulated mainly through rapid rather than slow periglacial mass movement (Merritt et al. 2003).

3.1.3. Ground-ice depressions and aeolian deposits: absent or unrecognised? Several Lateglacial periglacial features present elsewhere in the British Isles are absent from the literature on the periglaciation of Scotland. Ramparted ground ice depressions representing former pingos or lithalsas occur inside the limits of the last ice sheet in England, Ireland and Wales (Bryant \& Carpenter 1997; Ballantyne 2017) but have not hitherto been identified in Scotland. Similarly, although loess deposits of Dimlington Stadial age occur in NW England and coversands of YDS age occur in various parts of England (Bateman 1995; Murton \& Ballantyne 2017), Lateglacial aeolian deposits have not been reported in Scotland. The absence of loessic deposits may be explained by lack of a source of silt-sized sediment (Ballantyne \& Harris 1994). An alternative possibility is that loess and aeolian sands occur as allochthonous components within Scottish soils rather than discrete sediment facies, or have simply escaped recognition. Much our understanding of Lateglacial periglaciation in lowland Scotland relates to research published several decades ago, and there is a need for reinvestigation of lowland periglacial landforms and sediments, particularly in the light of recent advances in the interpretation of relict periglacial phenomena (Ballantyne 2017).

\subsection{Lateglacial periglaciation on Scottish Mountains}


Research on the landform assemblages produced by Lateglacial periglacial processes operating on high ground in Scotland is summarised in Ballantyne (1984) and Ballantyne \& Harris (1994). The account below focuses on more recent research. Figure 5a depicts the range of Lateglacial periglacial landforms on Scottish mountains.

3.2.1 Blockfields and tors. The higher parts of many Scottish mountains comprise undulating plateaux that represent the eroded relicts of uplifted palaeosurfaces (Hall 1991; Goodfellow 2007). Such plateaux are extensive in the Eastern Grampians and the Southern Uplands, but have been fragmented by glacial dissection in the Western Highlands and Hebrides. Plateaux and summits that escaped erosion by the last ice sheet are extensively mantled by blockfields (Fig. 6a), a term used here to denote all forms of bouldery plateau regolith. Studies of Scottish blockfields have shown that they developed primarily through frost weathering (Ballantyne 1998a, 2010b; Hopkinson \& Ballantyne 2014). Cosmogenic ${ }^{10} \mathrm{Be}$ exposure dating of erratics resting on blockfield debris, however, has demonstrated that Scottish blockfields survived burial by the last ice sheet because the ice covering plateaux was cold-based, frozen to the underlying substrate and hence moved through internal deformation alone, so that erosion by basal sliding did not occur (Fabel et al. 2012). It follows that although renewed frost action probably modified Scottish blockfields during the Lateglacial, they are essentially much older landforms. The same is true of the tors that have gradually emerged from plateau surfaces through differential weathering and erosion of palaeosurfaces, usually because they have lower joint density than the surrounding terrain (Ballantyne 1994; Goodfellow et al. 2014; Fig. 6b). Exposure dating of tors in the Cairngorms has demonstrated emergence since the Middle Pleistocene ( $\sim 920-130 \mathrm{ka})$, implying lowering of the surrounding palaeosurfaces by several metres to tens of metres during the last million years (Phillips et al. 2006).

3.2.2. Relict patterned ground and solifluction landforms. Plateau blockfields support relict sorted patterned ground features 1.5-4.5 m wide (Kelletat 1970; Ballantyne \& Harris 1994, p. 193-195). On low-gradient terrain these take the form of circles of boulders that grade into sorted stripes on slopes (Fig. 6c). Pattern margins are defined by boulders occupying broad troughs; exposed clast surfaces are rounded by granular disaggregation whereas subsurface clasts are usually angular, a contrast that indicates prolonged stability. The vegetation-covered fine cells or stripes separated by these bouldery domains comprise soil with occasional clasts. Formation of such large-scale sorted patterns is now widely attributed to differential frost heave of clast-rich frost-susceptible soil, which initiates clast movement towards pattern borders and compensatory movement of soil at depth towards pattern centres (Ballantyne 2013b; Hallet 2013). Because such patterns form only in frost-susceptible soils, they are common on regolith derived from metamorphic rocks but rare or absent on coarser grained lithologies (Ballantyne 1984). Sorted patterns exceeding $2 \mathrm{~m}$ in width usually indicate formation above permafrost. Although it is possible that bouldery patterned ground may have survived burial under cold-based ice, it is likely that the forms now visible were formed or reactivated under Lateglacial periglacial conditions.

Nonsorted vegetation-covered earth hummocks up to $0.5 \mathrm{~m}$ high and $\sim 2.0 \mathrm{~m}$ wide are also common on frost-susceptible regolith covers such as those of the Eastern Grampians, Ben Wyvis and higher summits in the Southern Uplands. On some plateau margins, hummocks grade into relief stripes (vegetated ridges and furrows aligned downslope) as the gradient steepens beyond 
6-11 $1^{\circ}$ (Fig. 6d). Excavations through hummocks and relief stripes have shown that the horizons of podzols parallel the surface microtopography, implying prolonged stability, and it is likely that these landforms represent differential frost heave of relatively clast-poor soils during the Lateglacial period (Ballantyne 1986a).

Lateglacial mass movement has produced large terraces and lobes of coarse bouldery debris. These are best developed on granite mountains, though similar features occur on most metamorphic rocks. Terraces comprising 1-3 m high bouldery risers and gently-sloping treads extend along slope crests for tens or hundreds of metres; with increasing gradient, terraces become crenulate in planform, and farther downslope over-riding of terraces has isolated individual boulder-fronted lobes (Fig. 6e). In the Cairngorms, boulder lobes extend downslope to $540 \mathrm{~m}$, but are absent from all areas occupied by glacier ice during the YDS, implying that movement ceased with the onset of rapid warming at $\sim 11.7 \mathrm{ka}$. The mechanism responsible for the downslope movement of such coarse bouldery debris is uncertain. Some authors have suggested that boulder lobes and terraces represent downslope movement of debris by creep of underlying ice-rich permafrost, analogous to the movement of coarse debris in rock glaciers ( $c f$. Kääb \& Kneisel 2006). An alternative explanation is that bouldery terraces and lobes are sorted solifluction landforms, similar to the 'stone-banked lobes' investigated by Benedict (1970), in which vertical and lateral frost sorting have resulted in concentration of coarse debris on the surface and margins, and that downslope movement resulted from solifluction of a buried core of finer sediment overlying permafrost. The morphological similarity of boulder terraces and lobes and active solifluction landforms (section 4.1.1) suggests that the latter explanation is more plausible, particularly as there appear to be no present-day analogues for terrace and lobe formation by permafrost creep.

Vegetation-covered, nonsorted Lateglacial solifluction terraces and lobes are also present on Scottish hillslopes, particularly on schists, outside the limits of YDS glaciation. These are typically 1-2 m thick, are often best developed where the gradient lessens at slope-foot locations, and can be distinguished from their Holocene counterparts by degraded risers and the absence of buried soil horizons.

3.2.3. Talus, protalus ramparts and rock glaciers. The term 'talus' describes aprons of rockfall debris that have accumulated below cliffs to form talus slopes comprising a quasirectilinear upper slope with a gradient of $33-39^{\circ}$ and a basal concavity. Most taluses in Scotland are essentially relict, vegetated landforms and many exhibit evidence for erosion by streams, translational landslides and debris flows (Fig. 6f). Although talus deposits are dominated by coarse debris, fine $(<2 \mathrm{~mm})$ sediment constitutes $27-30 \%$ by weight of the uppermost few metres of talus accumulations, and represents granular weathering of source rockwalls, grainfall on to talus surfaces and illuviation of fines within the talus body (Salt \& Ballantyne 1997; Hinchliffe et al. 1998).

It is widely accepted that most talus accumulation in Scotland occurred during the Lateglacial, with limited addition of rockfall debris during the Holocene. Taluses outside the limits of the LLR tend to be thicker, and to bury more of the source rockwall, than those inside these glacier limits, implying enhanced rockfall during the Lateglacial (Ballantyne \& Eckford 1984; Kotarba 1984). Enhanced rockfall during the Lateglacial is also implied by large lateral 
moraines at sites where LLR glaciers evacuated rockfall debris from cliffed source areas (Benn 1989). High rates of rockfall activity during the Lateglacial have been attributed to joint propagation within cliffs due to paraglacial stress release and frost wedging of jointed rockwalls under periglacial conditions (Hinchliffe \& Ballantyne 2009). For talus below the Trotternish Escarpment on Skye, Hinchliffe \& Ballantyne (1999) estimated that $\geq 80 \%$ of all rockwall retreat (and thus talus accumulation) occurred between ice-sheet deglaciation at $\sim 16.5 \mathrm{ka}$ and the end of the Lateglacial. Curry \& Morris (2004) subsequently applied a paraglacial exhaustion model to the Trotternish rockwall retreat rate data and similar data for two sites in Wales. This model suggests that $\sim 50 \%$ of talus accumulation occurred within 1000 years following deglaciation, and that rates of accumulation were negligible after $\sim 5000$ years, a proposition broadly supported by radiocarbon dating of buried soils within talus accumulations in NW Scotland (Hinchliffe \& Ballantyne 2009) .

There is evidence that debris flow activity was also widespread during the Lateglacial. In a few areas, stratigraphic evidence suggests extensive reworking of glacigenic drift by debris flows during or immediately after deglaciation (Benn 1992; Ballantyne \& Benn 1996; Bennett 1999). Radiocarbon dating of buried organic horizons within debris cones deposited by successive debris flows extends no earlier than $\sim 7 \mathrm{ka}$, but the oldest dated horizons at some sites overlie up to $10 \mathrm{~m}$ of earlier debris-flow deposits, implying that flows of greater magnitude and/or frequency occurred during the Lateglacial or early Holocene. Evidence for debris transport by snow avalanches during the Lateglacial is more elusive. Relict avalanche boulder tongues occur at the foot of taluses in Glen Feshie (Cairngorms) and Glen Taitneach (SE Grampians), but their age is unknown. It seems likely that powerful snow avalanches were common under stadial conditions during the Lateglacial, but if so the morphological signature of such events has probably been obliterated by Holocene debris flows (Luckman, 1992).

Although several accounts of Lateglacial rock glaciers have been published (Harrison et al. 2008), reinvestigation of putative rock glaciers suggests that most or all represent rockslide runout debris or drapes of glacially-deposited boulders (Ballantyne et al. 2009; Jarman et al. 2013); there appear to be no unequivocal examples of Lateglacial rock glaciers in Scotland. Similarly, some talus-foot debris accumulations originally interpreted as Lateglacial protalus ramparts (Ballantyne \& Kirkbride 1986) have subsequently been shown to represent arcuate rockslide deposits, formed where cascading debris impacted low-gradient terrain at the slope foot (Ballantyne \& Stone 2009).

\subsection{Lateglacial rock-slope failures}

The term 'rock-slope failure' (RSF) is here employed to encompass all types of downslope movement of large rock masses, including rockslides, toppling failures, large rockfalls and rock avalanches, as well as rock-slope deformations that involve displacement of large rock masses without release and runout of debris. Groundbreaking theses by Watters (1972) and Holmes (1984) demonstrated that large postglacial RSFs are widespread on the metamorphic rocks of the Scottish Highlands, and a compilation of documentary evidence (Ballantyne 1986b) identified 625 Scottish RSFs, of which 564 are located in the Highlands and Hebrides, 37 in the Midland Valley (mainly associated with scarps underlain by lavas and sills) and 24 in the Southern Uplands. Jarman $(2006,2007)$ subsequently estimated that the Highlands alone contain over 550 
RSFs, including 140 with areas $>0.25 \mathrm{~km}^{2}$ (Fig. 7). The great majority of these are seated on metasedimentary rocks of the Moine and Dalradian Supergroups. Cave \& Ballantyne (2016) have shown that the concentration of RSFs on schists is significantly greater than that on other lithologies, irrespective of outcrop area.

Catastrophic RSFs (slides, topples, rock avalanches and major rockfalls) tend to be characterised by headscarps and/or lateral scarps, a distinct failure plane and downslope translocation of failed rock in the form of a coherent mass, large blocks of intact rock, an apron of runout debris or, more rarely, large debris-flow lobes (Fig. 8a-e). Rock-slope deformations involve limited downslope displacement of largely intact rock masses; lateral margins are often indistinct and headscarps are not always present. Surface morphology is characterised by slope bulging, tension cracks near slope crests and arrays of antiscarps (uphill-facing scarps) aligned across-slope (Fig. 8f), and some exposures reveal flexural deformation and dislocation of bedding that extends tens of metres into the rock (Peacock \& May 1993). Rock-slope deformations may involve shift of entire mountainsides. The largest, on Beinn Fhada in Kintail, covers $\sim 3 \mathrm{~km}^{2}$ (Jarman \& Ballantyne 2002), and Jarman (2006) identified 89 rock-slope deformations $>0.25 \mathrm{~km}^{2}$ in area in the Scottish Highlands. He suggested that these can be subdivided into extensional and compressional types, but many exhibit extensional features on the upper slope and compressional features farther downslope.

Dating of 31 catastrophic RSFs in the Scottish Highlands and NW Ireland using cosmogenic ${ }^{10} \mathrm{Be}$ and ${ }^{36} \mathrm{Cl}$ (Ballantyne \& Stone 2013; Ballantyne et al. 2014a, 2014b) has allowed the age of these features to be determined and thrown light on the nature of triggering factors. Of 20 dated RSFs located outside the limit of the LLR, all but one occurred during the Lateglacial period, within $\sim 5.4 \mathrm{ka}$ after local deglaciation, with peak RSF activity $1.6-1.7 \mathrm{ka}$ after deglaciation (Fig. 9). Ballantyne et al. (2014a) inferred that this time lag represented timedependent reduction of rock-mass strength due to deglacial unloading, development of stressrelief joints and associated progressive development of a failure plane, leading either to spontaneous kinematic release or failure triggered by some extrinsic mechanism. Analysis of the timing of individual failures suggested that glacial debuttressing (removal of supporting glacier ice), enhanced water pressures during deglaciation and thaw of permafrost ice in rock joints could have triggered failure in only a small number of cases. Conversely, they demonstrated that the timing of maximum postglacial RSF activity was coincident with that of maximum rates of glacio-isostatic uplift (Fig. 10), suggesting that the two are linked by uplift-driven earthquake activity. A seismic failure trigger is consistent with full-slope failure at all sites where failure planes are clearly defined ( $c f$. Densmore \& Hovius 2000), and with independent evidence of uplift-driven fault movements and palaeoseismicity during the Lateglacial period (Davenport \& Ringrose 1987; Ringrose 1989a, 1989b; Firth \& Stewart 2000; Stewart et al. 2001; Smith et al. 2009). The timing of rock-slope deformations is unknown, though it seems likely that these also reflect rock mass weakening due to deglacial unloading, realignment of the principal stress field and progressive brittle damage (static fatigue) leading to creep of mountain slopes.

As almost all dated catastrophic RSFs located outside the limits of the LLR occurred during the Lateglacial, it is inevitable that numerous RSFs also occurred within LLR glacial limits, but are less conspicuous because all runout debris has been removed by LLR glacier ice. The sites of such RSFs are marked by debris-free failure scarps usually comprising a steep headscarp, a quasi- 
rectilinear or stepped failure plane and, in some locations, flank scarps, headscarp tension cracks and occasional in situ detached blocks near the headscarp (Ballantyne 2013c; Fig. 11). Survey of mountainous areas in NW Scotland and the Outer Hebrides has demonstrated that such debrisfree scarps are widespread on slopes $>25^{\circ}$, and, like other RSF sites, are preferentially developed on schists (Cave \& Ballantyne 2016). An implication of such debris-free scarps is that reworking of the debris deposited by numerous large-scale Lateglacial RSFs (and innumerable small valleyside RSFs) probably contributed significantly to the sediment transported by LLR glaciers, and thus to the volume of sediment contained within LLR moraines (Benn 1989).

\subsection{Lateglacial rivers}

The floors of major valleys throughout Scotland are occupied by valley fills, generally a few metres to several tens of metres thick, that separate present floodplains from the underlying rockhead. They may be compositionally simple, as where alluvium directly overlies bedrock, or stratigraphically complex, where glacifluvial or alluvial sediments deposited during and after deglaciation overlie glacigenic deposits. Much of our understanding of Lateglacial fluvial activity in Scotland arises from studies of terrace sequences flanking present floodplains, and alluvial fans deposited at the junction of tributary valleys.

3.4.1. Lateglacial terrace sequences. Terraces bordering present floodplains are essentially erosional landforms produced by river incision of former channels or floodplains. In some cases, particularly in the western Highlands, postglacial river incision into bedrock has produced 'strath terraces,' bedrock terraces that are sometimes overlain by a veneer of alluvium (section 4.4 .3 below). In others, generally in tributary valleys, rivers have cut down into glacigenic deposits, forming terraces underlain by till but capped by a thin cover of alluvial sediments representing the former level of the river. By far the most common Lateglacial terraces in major valleys, however, are those where glacifluvial deposits initially accumulated as sandar (braided outwash floodplains) that were then abandoned as a result of river incision.

Fluvial downcutting may be caused by either a drop in base level or a change in the balance between sediment supply and effective flood discharge. For rivers terminating at the coast, incision has been due to lowering of relative sea level caused by glacio-isostatic uplift (e.g. Gray 1975; Gray \& Sutherland 1977; Tipping et al. 1994; Bishop et al. 2005). Similarly, for rivers that drained into former ice-dammed lakes, lowering of lake level has resulted in fluvial downcutting and terrace development (Sissons 1977, 1979a, 1982; Sissons \& Cornish 1983; Russell 1995). More locally, where alluvial reaches terminate downvalley at a base-level represented by a bedrock reach, lowering of the bedrock channel by incision or knickpoint retreat has caused fluvial downcutting and terrace formation in the alluvial reach upstream (Young 1976). In upland valleys where valley fills are thin, multiple alluvial reaches are often separated by bedrock reaches that represent steps in the valley long profile produced by glacial erosion (Addy et al. 2014; Whitbread et al. 2015).

Aggradation or incision of alluvial or outwash deposits also depends on sediment supply and dominant river discharge. When sediment supply exceeds the transport capacity of a river, floodplain (or sandur) aggradation occurs. In major valleys, this situation was common during and immediately after ice-sheet deglaciation, when glacigenic sediments and those supplied by 
paraglacial hillslope processes were entrained by proglacial rivers and deposited on valley floors vacated by the retreating ice (Gray \& Sutherland 1977; Young 1978; Aitken 1998; Marren 2001). Subsequent reduction in proglacial and paraglacial sediment supply, however, has resulted in rivers cutting deeply into earlier outwash or alluvial deposits, leaving abandoned sandur or floodplain surfaces as terraces. Owing to fluctuations in both sediment supply and river discharge under the rapidly changing climate of the Lateglacial period (Fig. 2) it is possible that some valleys experienced two or more cycles of aggradation and incision, but the limited stratigraphic evidence available supports only a single cycle of initial sediment aggradation followed by pulsed or continuous incision (Aitken 1998; Marren 2001).

Scottish Lateglacial terraces fall into four categories: (1) kame terraces, formed by deposition of sediment by rivers at the lateral margins of glaciers, and abandoned during subsequent glacier thinning and retreat; (2) proglacial outwash terraces representing the remnants of former sandar; (3) alluvial terraces, representing the former floodplains of nonglacial rivers; and (4) river terraces associated with former ice-dammed lakes.

3.4.1.1 Kame terraces. Kame terraces formed both during the later stages of ice-sheet retreat $(\sim 17-15 \mathrm{ka})$ and during the YDS $(\sim 12.9-11.7 \mathrm{ka})$. They are often perched on hillslopes tens or even hundreds of metres above present floodplains, may contain kettle holes formed through melt of buried ice blocks and are frequently associated with ice-marginal meltwater channels. Kame terraces that formed at the margins of the last ice sheet are abundant along the flanks of Strathspey and the Dulnain valley (Young 1977, 1978) and the northern slopes of the Cairngorms, where the most extensive represent sediment infill of former ice-marginal lakes (Brazier et al. 1998; Everest \& Kubik 2006; Hall et al. 2016). High-level kame terrace fragments are also associated with ice-marginal meltwater channels in the upper Clyde, Annan and Tweed valleys of the Southern Uplands. Locally, an upper sequence of kame terraces may be succeeded downslope by terraces of other types. In the Streens Gorge in Strathdearn, for example, terrace fragments at 13 levels occur up to $80 \mathrm{~m}$ above the floodplain of the River Findhorn. Auton (1990) interpreted most of the higher benches as kame terraces, an intermediate terrace as a delta formed in an ice-marginal lake and the lowermost five terraces, $10-30 \mathrm{~m}$ above the present floodplain, as outwash or alluvial terraces. Kame terraces of YDS age formed along the lower margins of some outlet glaciers, for example in Glen Moriston (Sissons 1977) and along the shores of Loch Etive, where kettled kame terraces up to $400 \mathrm{~m}$ wide merge with a large kettled outwash terrace graded to a Lateglacial sea level of 10-12 m OD (Gray 1975, Fig. 12).

3.4.1.2 Outwash terraces. As argued by Sissons (1982), the great majority of terraces bordering the floodplains of major rivers throughout Scotland are probably outwash terraces that represent abandoned proglacial sandur surfaces. Such terraces typically extend up to $30 \mathrm{~m}$ above present floodplains (and occasionally higher) and support a microtopography of braided palaeochannels. Some are pitted with kettle holes, confirming a glacifluvial origin (Fig. 12). Most outwash terraces are largely or entirely composed of glacifluvial sands and gravels (Rhind 1969; Robertson-Rintoul 1986; Maizels \& Aitken 1991; Russell 1995; Aitken 1998; Marren 2001), implying that an initial phase of net glacifluvial sediment aggradation preceded net incision and terrace formation. There is, however, a marked contrast between the outwash terraces deposited during the retreat of the last ice sheet, which often rise 5-40 m above present floodplains (Fig. 13), and terrace heights in valleys formerly occupied by LLR glaciers. With the exception of LLR 
outwash terraces graded to high Lateglacial sea levels (Fig. 12) or to the levels of former icedammed lakes, the highest terraces inside LLR ice limits rarely occur more than a few metres above present river channels, and the limited dating evidence suggests that at least some these are of late Holocene age (section 4.4.1.1 below). One possible explanation for the apparent lack of LLR outwash terraces in Highland glens is that glacier retreat during the YDS generated high effective discharges, resulting in net incision rather than aggradation of proglacial sandar.

Maizels (1983a, 1983b) identified a sequence of four or five prominent outwash terraces bordering the floodplains of rivers draining eastwards from the Highland edge, all of which she attributed to the period of ice-sheet deglaciation. She speculated that each terrace could represent aggradation associated with brief readvances of the retreating ice margin and incision during ensuing ice-margin retreat, but there is no stratigraphic evidence supporting this view. The terraces are undated and contemporaneity of terraces between glens is uncertain. Focusing on an area of extensive development at the confluence of the North Esk and West Water near Edzell, she showed that although all terraces support braided palaeochannels, the degree of braiding declines from the uppermost (oldest) to lowest (youngest) terrace, accompanied by increase in sinuosity, changes that may reflect progressive establishment of a more stable channel system. Exposures in one terrace revealed massive, poorly-sorted imbricate gravels and cobbles with lenses of cross-bedded and plain-bedded sand, a lithofacies assemblage typical of an aggrading proglacial braided sandur. Palaeodischarges calculated by Maizels \& Aitken (1991) on the basis of channel dimensions and the calibre of bed material suggested declining maximum discharges from $\sim 18,000 \mathrm{~m}^{3} \mathrm{~s}^{-1}$ to $\sim 7000 \mathrm{~m}^{3} \mathrm{~s}^{-1}$, which they related to progressive reduction in glacier ice cover in the catchments. As they acknowledged, however, there is large uncertainty in calibration of palaeodischarge modelling parameters, which can lead to widely different estimates spanning two orders of magnitude (Church et al. 1990).

From logging and analysis of terrace deposits in the Don valley upvalley from Aberdeen, Aitken (1998) showed that these are characteristic of uninterrupted aggradation of proximal and distal braided outwash deposits, both lithofacies being interbedded with horizontal overbank sheetflow deposits. More locally, exposures in gravel pits have revealed a more complex lithostratigraphy that includes evidence of ice-marginal deltaic sediments capped by a proximal braided outwash sequence (Aitken 1995). The presence of numerous ice wedge pseudomorphs in the outwash deposits demonstrates that sandur aggradation occurred under permafrost conditions. Similarly, detailed analysis of palaeosandur deposits in the Lunan valley and Fife led Marren (2001) to conclude that these represent rapid aggradation during meltwater pulses associated with ablation-controlled discharges from glacier sources. Both studies imply that the development of outwash terraces was characterised by an initial aggradational phase during deglaciation, terminated by reduction in sediment supply and the onset of incision and terrace formation, rather than a more complex scenario involving multiple cycles of aggradation and trenching.

Outwash terrace sequences have also been reconstructed through mapping, survey and construction of height-distance diagrams that follow the valley long profile. Gray \& Sutherland (1977) used this approach to establish a relationship between former ice limits, outwash terraces and high $(>30 \mathrm{~m})$ Lateglacial sea levels at various sites in the Western Highlands, demonstrating thereby that the ice limits were asynchronous and linked to ice-sheet retreat rather than a later readvance. A similar approach was adopted by Young (1976) to analyse terrace sequences in 
Glen Feshie. From a large number of surveyed terrace fragments he identified five groups, all of which support braided palaeochannels. The uppermost three groups (1-3) begin in the central section of the glen, 25-40 m above the river, and decline steeply northwards towards a bedrock reach near the mouth of the glen; the highest and oldest terraces (groups 1 and 2) are locally kettled, confirming a glacifluvial origin. By contrast, the lowermost two groups (4 and 5) are present almost continuously throughout the length of the valley, roughly parallel to, and less than $5 \mathrm{~m}$ above, the present floodplain. Young's interpretation of the highest terraces is ambiguous: he described them both as kame terraces (implying an ice-marginal origin) but also (p. 509) as representing 'an initial floodplain up to $1700 \mathrm{~m}$ wide' (implying a proglacial origin). The abrupt up-valley termination of the high terraces of groups 1-3 he attributed to removal by later erosion, ignoring the possibility that glacier ice may have still occupied the upper valley throughout the period of higher terrace formation ( $c f$. Gray \& Sutherland 1977). A radiocarbon age of 4.1$3.9 \mathrm{cal}{ }^{14} \mathrm{C}$ ka obtained for charcoal fragments within an organic-rich layer buried by gravels within a low-level terrace (Robertson-Rintoul 1986) suggests that most or all of the low terraces in Glen Feshie are of late Holocene age. On the basis of soil-stratigraphic comparisons and assumed deglaciation ages, Robertson-Rintoul suggested that older terrace surfaces formed at $\sim 13$ and $\sim 10{ }^{14} \mathrm{C}$ ka BP $\left(\sim 15.6\right.$ and $\left.\sim 11.6 \mathrm{cal}{ }^{14} \mathrm{C} \mathrm{ka}\right)$. The former age is reasonably consistent with evidence for the timing of deglaciation of upper Strathspey (Ballantyne \& Small 2018); the latter implies terrace formation at the time of the Lateglacial-Holocene transition.

3.4.1.3. Lateglacial alluvial terraces. There is a remarkable lack of evidence concerning the behaviour of nonglacial rivers during the Lateglacial Interstade $(\sim 14.7-12.9 \mathrm{ka})$ and the YDS ( 12.9-11.7 ka; Fig. 2). Lewin \& Macklin (2003) have suggested that floodplain incision was dominant during the Lateglacial Interstade, and if so it is unlikely that evidence is preserved in alluvial archives. They also asserted that the YDS witnessed major renewed floodplain aggradation, contending that 'alluvial units of this period are common in both upland and lowland UK', and that the early Holocene was dominated by floodplain incision, allowing preservation of YDS alluvial units and terrace fragments. The only dated evidence for floodplain aggradation in Scotland during the YDS comes from the Kelvin valley, where cores record floodplain deposits overlain by peat then an upper layer of (Holocene) floodplain deposits (Tipping et al. 2008). The three oldest radiocarbon ages obtained for the base of the peat $(11.7-11.4,11.6-11.3$ and 11.2$10.8 \mathrm{cal}{ }^{14} \mathrm{C} \mathrm{ka}$ ) imply that the underlying alluvium is of YDS age, possibly indicating floodplain aggradation at that time.

3.4.1.4. River terraces associated with former lakes. During ice-sheet deglaciation, retreat of ice from some tributary valleys was succeeded by formation of lakes dammed by glacier ice occupying trunk valleys (e.g. Aitken 1990; Brazier et al. 1998; Everest \& Kubik 2006), and terraces formed upvalley from such lakes are related to former lake levels. Outwash and alluvial terraces in the Ochil Hills, for example, have been shown by Russell (1995) to relate to successive levels of a large lake in Glen Devon that was dammed by ice in the Forth Valley. The best-documented examples of glacier-lake-related terraces, however, are those associated with lakes dammed by ice during the LLR. From height-distance diagrams derived from survey of terrace fragments in upper Glen Doe and near Achnasheen, Sissons (1977, 1982) demonstrated that all but the lowest terraces relate to successive levels of former ice-dammed lakes. A similar approach allowed him to demonstrate that the altitudes of numerous fluvial terraces in Glen 
Spean were controlled by successive levels of an ice-dammed lake in the lower glen, and after lake drainage by the elevated level of Loch Lochy (Sissons 1979a). His 1982 paper on the Achnasheen terraces contains a summary of features that distinguish glacier-lake-related fluvial terraces, such as abrupt downvalley termination, abnormally steep gradients related to abruptly falling lake levels, and a tendency for terrace convergence and divergence downvalley. Sites of former ice-dammed lakes also contain Lateglacial or early Holocene terrace sequences formed where rivers have incised the former lake floor. In upper Glen Roy, for example, the River Roy has incised the former bed of a sequence of proglacial lakes that formed during the YDS to form a complex sequence of terraces and bluffs (Sissons \& Cornish 1983; Fig. 14b).

A unique lake-related terrace, the Auchteraw terrace near Fort Augustus, was interpreted by Sissons (1979b) as an outwash terrace deposited by a jökulhlaup (catastrophic drainage) of a lake dammed at $261 \mathrm{~m}$ OD by glacier ice in lower Glen Spean. He calculated that this lake had a volume of $\sim 5 \mathrm{~km}^{3}$ and used an empirically-derived relationship based on recent jökulhlaup events to retrodict a possible maximum discharge of $22,500 \mathrm{~m}^{3} \mathrm{~s}^{-1}$ during lake drainage. The Auchteraw terrace, which lies inside the LLR glacial limit and hence formed after the onset of glacier retreat, is a massive accumulation of predominantly coarse sediment, $\sim 3 \mathrm{~km}$ long, $\sim 1 \mathrm{~km}$ wide and $12-$ $16 \mathrm{~m}$ thick. Russell \& Marren (1998) have shown that the lithofacies and surface morphology of the terrace are consistent with Sissons' interpretation, and Russell et al. (2003) reported evidence of repeated episodes of high-energy deposition in terraced deposits near Spean Bridge, which they interpreted as evidence of later jökulhlaup floods that drained SW towards Loch Linnhe.

3.4.2. Lateglacial alluvial fans. Lateglacial alluvial fans are widespread throughout Scotland at the confluences of tributary streams with trunk valleys. In upland areas, fans deposited at the mouths of steep valleys form conspicuous sediment accumulations with surface gradients up to $10-12^{\circ}$; the steepest fans sometimes support bouldery lobes and levées, implying deposition by both flood torrents and channelized debris flows. Large, low-gradient fans occur at the confluences of major upland rivers, such as the Feshie and Spey (Werritty \& McEwen 1997). Lateglacial alluvial fans also occur in lowland areas (e.g. Auton \& Crofts 1986), but are poorly documented. The largest fans, for example in Glen Roy and Glen Banchor, span $>1500 \mathrm{~m}$ at their distal ends (Young 1978; Cornish 2017). The Lateglacial age of most fans is attested by morphostratigraphy: they commonly terminate on or merge with high-level outwash terraces, indicating contemporaneity (Young 1976, 1978). Subsequent incision of outwash deposits has caused trenching of fans by their parent streams, and formation of nested fans or inset terraces that often merge with lower outwash or alluvial terraces (Fig. 14).

Some Lateglacial fans, such as the Lindores fan in Fife (Marren 2001) or the Hillhead fan near Dyce (Aitken 1998) were fed by glacial meltwater, and should strictly be regarded as outwash fans, as should kettled fans such as that at the Tromie-Spey confluence (Young 1978). Most Lateglacial fans at the mouths of steep valleys are probably paraglacial landforms, however, fed by fluvial reworking of glacigenic sediments after ice sheet deglaciation. During this period, when sediment supplies were abundant, recurrent avulsion (channel switching) on fan surfaces accompanied rapid fan aggradation to produce lobate deposits that typically fine down-fan (Brazier 1987), and fan surfaces abandoned as a result of river incision often exhibit a complex pattern of palaeochannels. An outstanding example is the Allt Fheargenau fan in Glen Feshie (Werritty \& McEwen 1997), which merges with the highest outwash terrace fragments and was 
probably deposited shortly after local deglaciation at $\sim 16.5-15.5 \mathrm{ka}$. As with outwash terraces (section 3.4.1.2 above), there are marked contrasts in fan development inside and outside the limits of the LLR, fans inside these limits being generally much smaller (Brazier 1987). This contrast suggests that readily-entrainable glacigenic sediments in fan catchments were largely depleted after ice-sheet deglaciation, so that paraglacial fans deposited on valley floors vacated by retreating LLR glaciers were sediment-limited.

Much of the literature on Lateglacial fans focuses on those in Glen Roy, where shorelines along valley-side slopes record the former existence of a sequence of lakes (at $261 \mathrm{~m}, 325 \mathrm{~m}$ and $350 \mathrm{~m}$ ) that were dammed by glacier ice during the LLR (Fig. 14). This glen contains some of the largest valley-side fans in Scotland, but their origin has proved controversial. From the lithostratigraphy of three fans, Peacock (1986) inferred that these are paraglacial landforms that accumulated during the Lateglacial Interstade $(\sim 14.7-12.9 \mathrm{ka})$. A fourth fan, the Turret fan, was interpreted by Sissons \& Cornish (1983) as an ice-proximal outwash fan deposited in the lowest (261 m) lake, but reinterpreted by Peacock as an older landform that formed during ice-sheet retreat. Cornish (2017) reinvestigated several of the Glen Roy fans and identified a consistent threefold stratigraphy comprising lacustrine sediments underlain by thick $(>20 \mathrm{~m})$ gravels and overlain by a thin gravel cap. He proposed that the lower gravels represent deposition in shallow water during the rising lake sequence, followed by deposition of lacustrine sediments as lake levels rose higher and finally subaerial deposition of gravels as lake levels fell. Absence of foreset beds and Gilbert-type deltas was attributed by Cornish to deposition in shallow water, and the thickness of the gravel beds led him to infer that LLR glaciers were probably present in fan catchments, implying that the fans are essentially sublacustrine outwash fans rather than paraglacial fans. The origin of the Turret fan remains controversial: some authors favour the original LLR ice-contact interpretation (Cornish 2017; Lowe et al. 2017; Palmer \& Lowe 2017) whilst others have argued that LLR glacier ice failed to reach the proximal end of the fan and that it represents pre-YDS deposition (Peacock 1995; Boston \& Lukas 2017). Floodplain incision after drainage of the $261 \mathrm{~m}$ lake (Sissons \& Cornish 1983) and reduction in sediment supply has resulted in trenching of the Glen Roy Fans, producing inset terraces and distal bluffs (Fig. 14).

\section{Holocene landscape evolution}

\subsection{Holocene periglacial environments on high ground}

It is likely that the present maritime periglacial conditions on high plateaux and summits in Scotland are reasonably representative of conditions throughout most of the Holocene. The present climate of ground above $700-800 \mathrm{~m}$ is characterised by shallow ground freezing, extreme wetness and strong, gusty winds (Ballantyne 1987). Mean annual air temperatures exceed $0^{\circ} \mathrm{C}$ even on the highest summits, and air temperatures below $-10^{\circ} \mathrm{C}$ are infrequent. Permafrost is absent, though seasonal ground freezing may reach depths of $0.4-0.5 \mathrm{~m}$ in shaded sites. All but the most easterly summits receive $>2000 \mathrm{~mm} \mathrm{a}^{-1}$ precipitation, with some summits in the Western Highlands receiving $>4000 \mathrm{~mm} \mathrm{a}^{-1}$. During much of the last century average snow-lie ( $\geq 50 \%$ cover) exceeded 100 days per year at $600 \mathrm{~m}$ altitude and $150-180$ days per year at $900 \mathrm{~m}$, though in recent years snow has been less persistent. Scottish mountains support a wide range of active periglacial features (Fig. 5b), most or all of which have probably been present throughout the Holocene. 
4.1.1. Holocene frost weathering, patterned ground and solifluction features. Glacially-moulded bedrock surfaces on high ground exhibit only superficial evidence of clast detachment, suggesting that frost wedging or frost shattering of bedrock has been limited during the Holocene. Conversely, many exposed bedrock and clast surfaces are subangular to rounded (Fig. 15a), implying the operation of granular disaggregation by frost. The widespread occurrence of high-level aeolian deposits and aeolisols (section 4.1.2) suggests that granular weathering of bedrock and clasts has persisted throughout the Holocene.

Active frost-sorted patterned ground features (circles, nets and stripes) on Scottish mountains rarely exceed $0.7 \mathrm{~m}$ in width, are restricted to unvegetated, frost-susceptible soils, and have been produced by lateral sorting of small $(<15 \mathrm{~cm}$ long) clasts into shallow troughs 5$20 \mathrm{~cm}$ deep. The main sorting process is differential growth of needle-ice crystals during periods of shallow, often nocturnal, ground freezing (Ballantyne 1996), and miniature sorted patterns occur both on high ground and (more rarely) on unvegetated soil at low altitudes. The most impressive active sorted patterns are the stone stripes at $\sim 640 \mathrm{~m}$ on the felsite regolith of Tinto Hill in the Southern Uplands (Fig. 15b). Well-developed sorted stripes re-form on dug-over ground at this site within one to three winters, and painted clasts on stripes have moved downslope through needle-ice creep on a gradient of $23^{\circ}$ at rates of $243-620 \mathrm{~mm} \mathrm{a}^{-1}$ (Ballantyne 2001a).

Holocene solifluction landforms are widespread on many mountains above 550-600 m, particularly on schists that have weathered to produce frost-susceptible soils. On gentle to moderate slopes these take the form of flights of vegetated solifluction terraces that terminate downslope at steep risers $0.2-1.0 \mathrm{~m}$ high (Fig. 15c). On steeper slopes the risers take the form of a series of solifluction lobes arrayed across the slope. Although morphologically similar to relict solifluction landforms, active terraces and lobes have lower but steeper (sometimes bulging) risers, and often overlie organic soil horizons that have been buried by downslope movement of soil. Radiocarbon dating of buried organic matter has demonstrated movement of solifluction lobes over at least the past 5500 years (Sugden 1971; Mottershead 1978) and segmented tubes installed in three lobes on the Fannich Mountains and excavated after 35 years indicated average surface velocities of 7.8-10.6 $\mathrm{mm} \mathrm{a}^{-1}$, declining exponentially to zero at depths of $29-45 \mathrm{~cm}$ (Ballantyne 2013d; Fig. 15d). There is also evidence that lobes periodically rupture, burying the soil downslope under liquefied soil and debris. Five ${ }^{14} \mathrm{C}$ ages obtained from soil buried under a solifluction lobe in the Fannich Mountains produced ages ranging from $890 \pm 120$ to $530 \pm 90{ }^{14} \mathrm{C}$ a BP $\left(900 \pm 200\right.$ to $\left.550 \pm 170 \mathrm{cal}{ }^{14} \mathrm{C} \mathrm{a}\right)$, statistically indistinguishable from that that $\left(660 \pm 70{ }^{14} \mathrm{C}\right.$ a BP or $680 \pm 100 \mathrm{cal}{ }^{14} \mathrm{C}$ a) of the same soil horizon immediately downslope (Ballantyne 1986c), and thus suggesting almost instantaneous soil burial. It seems likely that lobe development involves a cycle of slow thickening and steepening of risers terminated by infrequent frontal rupturing, deposition of sediment a few metres downslope, then renewed slow thickening through solifluction ( $c f$. Kinnaird and Lewkowicz 2006).

Intimately associated with active solifluction terraces and lobes are ploughing boulders, which have moved downslope faster than the surrounding soil, leaving a vegetated furrow upslope and sometimes pushing up a ridge of soil downslope. Most occur on vegetated slopes of $8-30^{\circ}$, and recent activity is indicated by a niche that extends to the base of the boulder at its upslope end. Averaged rates of recent boulder movement range from $1.5-7.0 \mathrm{~mm} \mathrm{a}^{-1}$ on the 
Drumochter Hills and $0.3-8.7 \mathrm{~mm} \mathrm{a}^{-1}$ on Lochnagar, to $3.6-30.3 \mathrm{~mm} \mathrm{a}^{-1}$ on the Fannich Mountains (Ballantyne 2001b). Boulder movement has been attributed to ice lens formation under boulders during seasonal freezing and consequent generation of high pore-water pressures at the base of boulders during thaw, allowing them to slide downslope over softened or liquefied soil (Wilson 1993; Ballantyne 2001b).

4.1.2. Holocene aeolian landforms and deposits on high ground. The strong winds that sweep across high ground in Scotland have produced a wide range of distinctive landforms. Wind-driven sand particles have abraded boulders on some lithologies producing ventifacts that display distinctive facetted, fluted, pitted and polished surfaces (Christiansen 2004), and the interaction of wind stress, frost action and vegetation cover has produced a range of aeolian microforms on exposed plateaux and high cols. This includes isolated deflation scars, wind stripes (straight or wavy lines of vegetation alternating with bare ground) and wind crescents, arcuate clumps of vegetation that slowly migrate downwind across bare ground (Bayfield 1984; Fig. 16a). On higher slopes, turf-banked terraces with unvegetated treads and vegetated risers extend horizontally or obliquely across the slope. The evolution of these features is uncertain, but probably attributable to the formation of wind stripes that retard downslope movement of soil by solifluction (Ballantyne \& Harris 1994).

The most extensive products of wind erosion are deflation surfaces, expanses of bare ground where stripping of vegetation cover has exposed the soil to wind scour that has winnowed away particles up to $4-6 \mathrm{~mm}$ in diameter, leaving a sterile surface carpeted by boulders and a gravel lag. Superb examples occur on granite and sandstone mountains, but deflation surfaces occur on all lithologies and are present as low as $350 \mathrm{~m}$ in Orkney and Shetland. In some locations, vegetated 'islands' of aeolian sand deposits or aeolisols are present, demonstrating that sand or soil cover was formerly more extensive (Birse 1980; Ballantyne \& Morrocco 2006; Fig. 16b). A few plateaux support a more extensive mantle of aeolian sediment, preserved under vegetation cover. A remarkable example of intact aeolian deposits up to $2.9 \mathrm{~m}$ thick occurs on the summit of The Storr $(719 \mathrm{~m})$ in northern Skye (Fig. 16c), immediately above basalt cliffs exposed by a rockslide at $6.1 \pm 0.5 \mathrm{ka}$ (Ballantyne et al. 1998). The aeolian deposits thin away from the plateau edge, and radiocarbon dating of buried soils shows that the onset of aeolian deposition coincided with exposure of the rockwall, indicating that the aeolian deposits represent grains released from the rockwall by weathering and blown upwards on to the plateau, where they were anchored by vegetation cover (Ballantyne 1998b). Other plateau-top aeolian sands on Scottish mountains may have a similar origin, though some appear to be derived from nearby deflation surfaces.

Most high-level aeolian deposits, however, take the form of vegetation-covered sand sheets on lee slopes below plateau crests. Such plateau-margin aeolian sands achieve their greatest extent and thickness (up to $4.0 \mathrm{~m}$ ) on Torridon Sandstone mountains, but also occur at the margins of plateaux underlain by granite, quartzite, volcanic rocks and schists. On An Teallach in NW Scotland, a lower unit of weathered sand is overlain by an upper unit of fresh unweathered sand up to $2.3 \mathrm{~m}$ thick (Ballantyne \& Morrocco 2006; Fig. 16d). Radiocarbon dating of organic material at the base of the lower unit has shown that it began to accumulate in the early Holocene (Ballantyne \& Whittington 1987), and optically-stimulated luminescence (OSL) dating of the contact between the two units has shown that deposition of the upper unit commenced in 
AD 1550-1700, coincident with the onset of catastrophic erosion of plateau sand deposits upwind, where only isolated remnants now survive. OSL dating of plateau-margin sand deposits on other mountains has demonstrated that stripping of plateau-top sand deposits and aeolisols began at roughly the same time (Morrocco et al. 2007), suggesting that widespread erosion of plateau aeolian deposits and aeolisols may have been triggered by extreme climatic conditions during the Little Ice Age of the 16th-19th centuries. Most plateau-margin sand deposits are bordered by eroded scarps indicative of recent erosion, particularly by runoff from late-lying snowbeds (Ballantyne 1985).

\subsection{Holocene modification of sediment-mantled hillslopes}

The retreat of glacier ice at the end of the YDS left many lower slopes blanketed in a mantle of glacigenic sediment, often composed of stacked lateral moraines. In most areas, particularly on slopes $<25^{\circ}$, such drift cover has remained intact except where dissected by streams. In others, it has been extensively reworked, particularly by debris flow, the rapid downslope flow of poorlysorted debris mixed with water (Brazier et al. 1988; Brazier \& Ballantyne 1989; Curry 2000a, 2000b; Milne et al. 2010, 2015). Debris flows have also eroded regolith-mantled slopes (Innes 1986; Reid \& Thomas 2006; Fig. 17), and have played a key role in Holocene modification of relict talus accumulations (Hinchliffe et al. 1998; Hinchliffe \& Ballantyne 2009; Strachan 2015). They can be classified as hillslope flows, initiated by translational landsliding on open slopes, or channelized (valley-confined) debris flows that develop in gullies. In practice, however, the two categories are often transitional, as flows initiated in gullies can encroach on open slopes and flows originating on open slopes may become focused within gullies. Hillslope flows usually originate on gradients of $28-40^{\circ}$, and are particularly common on slopes mantled by sediment with a sandy matrix (Innes 1986; Milne et al. 2015), though some may incorporate a component of Holocene peat (Strachan 2017). Channelized flows may be initiated on slightly lower gradients. At many locations, deposition of sediment by recurrent debris flows following the same track has resulted in the accumulation of slope-foot debris cones that often support a microtopography of debris-flow levées and terminal debris lobes. Good examples line the flanks of glacial troughs such as Glen Etive, Glen Coe, Glen Docherty and Gleann Einich (Fig. 18).

Debris flow is presently the dominant agent of sediment transport on steep drift-mantled slopes throughout the Highlands and Southern Uplands, and along the steep flanks of igneous hills of the Midland Valley (Ballantyne \& Eckford 1984; Jenkins et al. 1988). Most recent individual flows are small and involve $<100 \mathrm{~m}^{3}$ of sediment, though some have transported $>1000 \mathrm{~m}^{3}$, and Milne et al. (2015) have shown that both the volume of transported debris and travel distance are strongly correlated with slope length. All documented instances of recent debris-flow events in Scotland occurred during prolonged rainstorms of exceptional intensity, and the recurrence interval of flow events at sites prone to debris-flow activity is thought to be roughly 10-50 years (Ballantyne 2002c). An intense rainstorm in 1978 triggered 71 individual flows in the Lairig Ghru in the Cairngorms (Luckman 1992) and another in August 2004 generated 31 debris flows within Glen Ogle in Perthshire (Milne et al. 2009, 2010), two of which trapped 57 people who had to be airlifted to safety (Winter et al. 2006).

Relict talus accumulations of Lateglacial or early Holocene age have been extensively reworked by recurrent debris flows, which have eroded deep gullies in upper talus slopes and 
deposited debris cones at slope foot. Gully-wall exposures through taluses on Skye and in the NW Highlands have revealed stacked debris-flow deposits intercalated with gravelly slopewash beds and/or buried organic soils of Holocene age (Salt \& Ballantyne 1997; Hinchliffe et al. 1998; Hinchliffe 1999; Fig. 19), underlain at some sites by a clast-supported diamicton representing unmodified rockfall debris. The stratigraphy and dating evidence from these sites has been employed by Hinchliffe and Ballantyne (2009) to derive a general model of talus evolution in Scotland. They proposed that an initial phase of paraglacial (Lateglacial or early Holocene) talus accumulation was succeeded by erosion and redeposition of sediment near the crest of talus slopes by translational failure, debris flow and slopewash, forming gullies that progressively extended downslope, trenching earlier slopewash and debris-flow deposits and feeding slope-foot debris cones to form the present talus landsystem (Fig. 20). This model resembles the sequence of paraglacial evolution of drift-mantled slopes following recent deglaciation (Ballantyne and Benn 1994, 1996; Curry, 1999b), except that in the case of relict talus slopes an initial phase of rockfall accumulation precedes the onset of net erosion.

The timing of Holocene debris-flow activity at several sites in the Highlands has been investigated through radiocarbon dating of buried soil or peat layers underlying or intercalated with debris flow deposits. Such organic layers imply a prolonged period of stability between flow events. Radiocarbon dates obtained from the tops of organic layers provide a maximum age for the overlying debris-flow deposit, and those obtained from the base of organic layers yield a minimum age for the underlying deposit. The dating evidence from nine sites in the Highlands (Fig. 21) shows that intermittent debris-flow activity has reworked glacial drift, talus deposits and weathered bedrock over at least the last 7000 years; the absence of older organic layers is probably a sampling artefact, as most sampled exposures are $<3 \mathrm{~m}$ deep. Although these data show that debris-flow activity has occurred throughout much of the Holocene, clustering of radiocarbon ages suggests that enhanced activity may have occurred within the last 700 years, 1700-2700 years ago and (more tentatively), 3400-3800 and 5900-6400 years ago. The longterm causes of enhanced debris flow activity are uncertain. Progressive pedogenesis may have reduced the shearing resistance of sediment-mantled hillslopes (Brooks et al. 1995) and it is possible that burning, deforestation or grazing pressure may locally have increased the susceptibility of slopes to failure and flow (Innes 1983; Hinchliffe 1999). Most authors have concluded, however, that exceptional rainstorm events, possibly related to longer-term climatic changes, represent the most likely explanation for debris-flow activity (Brazier \& Ballantyne 1989; Hinchliffe 1999; Curry 2000a, 2000b; Reid \& Thomas 2006).

Conversely, lichenometric dating of boulders on debris-flow deposits at twelve sites in the Highlands by Innes (1983) initially appeared to indicate negligible activity prior to about AD 1700 , and accelerated activity thereafter. This approach, however, suffers from the drawback that recent debris flows have tended to bury older debris flow deposits, introducing a sampling bias that favours younger flow ages. Luckman (1992), for example, demonstrated that flows generated by the 1978 rainstorm in the Lairig Ghru largely obliterated a previous generation of debris-flow lobes deposited by a similar event in 1956. Geomorphological evidence nevertheless suggests that the past few decades or centuries may have witnessed enhanced debris-flow activity at some sites in the Highlands. If sites that have experienced recent widespread debris flow activity (such as the Lairig Ghru, Gleann Einich and Glen Docherty; Fig. 18) had experienced a similar 
frequency of debris-flow events throughout the Holocene, sediment cover on these slopes is likely to have been extensively depleted within a few centuries or millennia ( $c f$. Ballantyne \& Benn 1994, 1996; Curry 1999b). That this is not the case suggests enhanced recent debris-flow activity at such sites, though the possible causes of such activity remain a source of debate (Innes 1983; Brazier \& Ballantyne 1989; Ballantyne 1991).

Although debris flow represents the dominant (and morphologically most conspicuous) agent responsible for modifying sediment-mantled hillslopes, other processes have also contributed to Holocene slope evolution. Flood torrents have dissected moraines on lower slopes, locally depositing sediment as small alluvial fans (Brazier et al. 1988; Ballantyne \& Whittington 1999). There is also persuasive evidence, particularly for the Southern Uplands, to indicate that woodland clearance and other land-use changes during the past four millennia have made driftmantled slopes more vulnerable to gully erosion, resulting in the deposition of small fans on valley floors (Chiverrell et al. 2007; Foster et al. 2008; section 4.4.2) Translational landslides have also affected many drift-covered slopes, leaving cuspate scars, particularly above steep bluffs where streams have incised till deposits (Fig. 22). A related phenomenon is the occurrence of peat slides, which involve translational sliding of intact bodies of peat over rockhead or underlying mineral soil. Such events are triggered by extreme rainstorms, usually following a period of wet weather (Acreman 1991; Moore et al. 2006; Dykes \& Warburton 2008; Nichol 2009), and resultant increase in pore-water pressure at the base of the peat. Recorded examples have involved peat bodies up to about $3 \mathrm{~m}$ thick and $59,000 \mathrm{~m}^{3}$ in volume. The resultant landforms include arcuate or irregular failure scars, intact rafts of displaced peat, fragmented peat blocks and sometimes pressure ridges at the distal end of individual slides. Most reported examples occur on Shetland (Veyret \& Coque-Delhuille, 1983; Moore et al. 2006; Dykes \& Warburton 2008), but this may reflect under-reporting of those in other upland areas.

Evidence for recent snow avalanche activity in mountain areas is usually confined to uprooting of turf, localised erosion of talus and deposition of a thin spread of soil and debris downslope (Ward 1985; Ward et al. 1985). More substantial Holocene snow avalanche landforms are limited to a small number of sites, such as an avalanche impact pit and rampart below the north face of Ben Nevis (Ballantyne 1989) and avalanche boulder tongues in the Cairngorms. The finest examples are in the Lairig Ghru, where avalanche tongues extend across the valley floor and up the opposing slope, damming the Pools of Dee at the highest point in the glen (Luckman 1992).

\subsection{Holocene rock-slope failures}

Although the great majority of RSFs in Scotland occurred during the Lateglacial (Ballantyne 2013c; Ballantyne et al. 2014a), intermittent catastrophic RSFs have punctuated the Holocene. A few occurred during the final centuries of the YDS, depositing debris on LLR glaciers, notably at the foot of Maol Cheann-dearg (Torridon; dated by cosmogenic ${ }^{10} \mathrm{Be}$ to $12.2 \pm 0.5 \mathrm{ka}$ ) and in Coire nan Arr (Applecross; $12.5 \pm 0.6 \mathrm{ka}$ ). Others distributed rockslide runout debris across terrain recently vacated by LLR glacier ice, as at Carn Ghluasaid (Cluanie; $12.4 \pm 0.7 \mathrm{ka}$ ) and Beinn an Lochain (Arrochar; $11.5 \pm 0.6 \mathrm{ka}$ ). The temporal pattern of 11 dated RSFs following YDS deglaciation, however, differs from that following ice-sheet deglaciation (Fig. 9), in that these occurred throughout most of the Holocene, with no evidence for a pronounced post- 
deglaciation peak in RSF activity. This contrast probably reflects differences in the duration and dimensions of ice-sheet glaciation and those of glaciation during the LLR. During the former, an extensive ice sheet was present for $\sim 14,000$ years $(\sim 30-16 \mathrm{ka})$ and overtopped even the highest summits (Hubbard et al. 2009; Clark et al. 2012; Fabel et al. 2012; Ballantyne \& Small 2018). Conversely, most YDS glaciers in Scotland existed for less than $\sim 1200$ years, were largely confined to glacial troughs and accomplished comparatively limited landscape modification (Golledge 2007, 2010; Golledge et al. 2008). The apparent absence of a peak in Holocene RSF activity probably reflects relatively limited and brief loading and unloading of slopes by LLR glaciers, combined with declining rates of glacio-isostatic uplift (Fig. 10) and associated seismic activity. Notable Holocene RSFs include that from the south face of Beinn Alligin (Torridon) at $\sim 4.3 \mathrm{ka}$, when $\sim 9 \mathrm{Mt}$ of bedrock failed along a $42^{\circ}$ failure plane bounded by converging fault scarps, and coarse rock debris extended along the corrie floor for $1.25 \mathrm{~km}$ (Ballantyne 2003b; Ballantyne \& Stone 2004); the Storr landslide ( 6.1 ka) on the Trotternish Escarpment, Skye, which produced the $49 \mathrm{~m}$ high pinnacle of the Old Man of Storr (Ballantyne 2007a); and the rock avalanche near the mouth of Coire Gabhail (the Lost Valley) near Glen Coe, where $\sim 0.6 \mathrm{Mt}$ of rhyolitic ignimbrite failed about 1700 years ago, damming the upper glen (Ballantyne 2007b). The absence of any trend in the timing of dated catastrophic Holocene RSFs in the Highlands suggests that the probability of such failures has changed little over the past $\sim 10 \mathrm{ka}$ (Ballantyne \& Stone 2013).

\subsection{Holocene fluvial environments}

There has been considerable debate as to whether the pattern and timing of Holocene alluvial aggradation and incision reflects (1) long-term climatic fluctuations; (2) exceptional flood events, possibly related to such wetter or cooler periods; (3) natural changes in the vegetation and peat cover of catchments; (4) anthropogenic influences, due particularly to the effects of woodland clearance, burning and grazing pressure in altering runoff regime and lowering the threshold for hillslope erosion of hillslopes; or (5) autogenic changes in alluvial reaches, locally related to changes in base level. This issue has been addressed both for individual catchments, as outlined below, and through compilation of UK-wide datasets based on radiocarbon dating of organic material buried, overlying or contained within alluvial sediments. Based on such evidence Macklin et al. $(2010,2013)$ identified 17 multi-centennial periods of flooding and river instability during the Holocene and six periods of accelerated incision for the UK as a whole; subdivision of their dataset also allowed periods of 'instability' and 'stability' to be identified for particular regions. From the available data from nine sites in the NW Highlands and W Grampians, for example, they identified 'instability' in fluvial systems at 3.8-3.3 ka, 2.3-1.7 ka, 1.4-1.1 ka and $0.7-0.5 \mathrm{ka}$.

The validity of this approach for Scotland is questionable. It lumps together not only radiocarbon ages from major floodplains and from small alluvial fans, which may have responded to entirely different controls, but also incorporates ages for manifestly non-alluvial settings, such as buried soils within the upper parts of talus slopes (e.g. Hinchliffe 1999) and inwash of soil into peat-filled upland basins (e.g. Tipping 1995a). Such cavalier misappropriation of radiocarbon ages from non-alluvial settings compromises the integrity of the datasets and undermines the confidence that can be placed in such meta-analyses. 
Even after exclusion of inappropriate sites, the limited dating evidence for the behaviour of Scottish river systems is incompatible with such an approach, for two main reasons. First, changes in river behaviour during the late Holocene took place against a backdrop of spatiallydiachronous anthropogenic influence, particularly through woodland clearance, burning, grazing pressure and expansion of agriculture. Second, because major rivers generally occupy broad valleys, there is usually imperfect coupling between hillslopes and steep tributary valleys with main channels: sediment has often been deposited as alluvial fans and debris cones along the flanks of major valleys rather than entering trunk rivers. In consequence, there is marked asynchronicity between periods of floodplain aggradation and episodes of fan accumulation (e.g. Tipping \& Halliday 1994; Ballantyne \& Whittington 1999; Reid et al. 2003; Foulds \& Macklin 2006). There is also evidence that periods of floodplain aggradation or incision may even be asynchronous within a single catchment (e.g. Tipping 1999; Tipping et al. 1999), and that the Holocene history of lowland rivers differs from that of upland rivers (Tipping et al. 2008).

4.4.1. Holocene floodplains and terraces. The available evidence suggests that there may be systematic contrasts in floodplain and terrace evolution in the Highlands, Southern Uplands and Midland Valley; these regions are considered in turn below.

4.4.1.1. The Scottish Highlands. Low-level terraces (usually $<3-4 \mathrm{~m}$ above the active floodplain) are widespread in alluvial reaches of the main Highland glens (Robertson-Rintoul 1986; Rumsby et al. 2001; Ballantyne 2008). Dating evidence exists for only three sites, all of which indicate floodplain aggradation then incision during the late Holocene. In Glen Licht (Kintail) the base of an extensive peat layer overlying a low alluvial terrace has yielded three similar radiocarbon ages averaging $\sim 4.5 \mathrm{cal}{ }^{14} \mathrm{C}$ ka (Reid et al. 2003); assuming that peat growth commenced shortly after floodplain abandonment, this date marks the approximate culmination of floodplain aggradation and is maximal for subsequent incision. In upper Glen Feshie, a single radiocarbon age of $4.1-3.9 \mathrm{cal}{ }^{14} \mathrm{C}$ ka was obtained by Robertson-Rintoul (1986) for charcoal fragments in an organic layer buried by alluvial gravels that form a low terrace, and hence constrains subsequent aggradation then incision. In the Edendon valley near Drumochter, Ballantyne \& Whittington (1999) showed that Holocene floodplain aggradation peaked between $\sim 2.7$ and $\sim 2.4 \mathrm{cal}{ }^{14} \mathrm{C}$ ka about $2 \mathrm{~m}$ above the active channel. The widespread occurrence of a prominent low terrace flanking alluvial reaches of major valleys in the Highlands (particularly the Eastern Grampians) led Ballantyne (2008) to conjecture that late Holocene aggradation then incision may have been widespread in the Highlands, producing what he termed the Main Holocene Terrace, but this requires testing through targeted dating of organic material below and overlying the terrace surface. All higher terraces in the Highlands appear to be of Lateglacial age (section 3.4.1), suggesting that floodplain stability or net incision characterised much of the earlier Holocene. The pattern of floodplain aggradation and incision for rivers terminating at the coast, however, has been distinctly different, being related to rise and fall of relative sea level, so that prominent terraces merge downstream with raised beaches (Tipping et al. 1994).

4.4.1.2. The Southern Uplands and Cheviot Hills. Much of current understanding of floodplain changes and terrace development in the Southern Uplands and Cheviots stems from studies by Richard Tipping and his co-researchers, who combined field survey, logging of exposures, sediment analysis and radiocarbon dating of buried organic material with analyses of pollen spectra and archaeological evidence in attempts to link river behaviour to climate change 
and/or anthropogenic influences. For rivers draining the Cheviots, Tipping's research suggests diverse sequences of floodplain evolution. The top of a peat layer underlying extensive terrace gravels at Wooler Water produced an age of $4.2-4.0 \mathrm{cal}{ }^{14} \mathrm{C} \mathrm{ka}$, and roots at the base of terrace gravels flanking a tributary of Bowmont Water yielded an age of $4.6-4.3 \mathrm{cal}{ }^{14} \mathrm{C} \mathrm{ka}$. Tipping (1992) considered these ages 'broadly synchronous' with palynological evidence for Neolithic woodland clearance $\left(\sim 4.7-4.2 \mathrm{cal}{ }^{14} \mathrm{C} \mathrm{ka}\right)$, and inferred that subsequent floodplain aggradation may reflect deforestation and increased sediment supply. In the upper Bowmont Valley, the highest terrace is undated, but the abandonment of a second terrace appears to have occurred within the past 350-220 years, leading Tipping (1994) to suggest that subsequent floodplain incision may have been due to increased flood activity during the Little Ice Age. At Akeld Steads, on the floodplain of the River Glen, radiocarbon ages for peat samples recovered from cores indicate trenching during the YDS, succeeded by peat accumulation interrupted by episodes of overbank sedimentation throughout the Holocene until $\sim 4.0-3.5 \mathrm{cal}{ }^{14} \mathrm{C} \mathrm{ka}$, with no evidence of intervening or subsequent incision (Tipping 1998). These contrasts in alluvial history illustrate the difficulty of attributing fluvial response to a general sequence of events related to climate changes or anthropogenic impacts.

Complications in the interpretation of Holocene alluvial sequences are also illustrated by research on the floodplain sequence in upper Annandale, where cores have revealed intercalated sequences of peat and overbank deposition (Tipping 1999; Tipping et al. 1999). An upstream transect records overbank sedimentation between $\sim 4.8$ and $\sim 3.9 \mathrm{cal}{ }^{14} \mathrm{C} \mathrm{ka}$, but this sequence is absent in cores retrieved farther downvalley. Renewed sedimentation, coeval with Iron Age settlement expansion, is recorded between $\sim 3.0$ and $\sim 2.1$ cal ${ }^{14} \mathrm{C} \mathrm{ka}$, but is diachronous across the floodplain. A major aggradational event at $\sim 1.9-1.5 \mathrm{ka} \mathrm{cal}{ }^{14} \mathrm{C} \mathrm{ka}$ was attributed by Tipping et al. (1999) to anthropogenic impacts, and a final period of extensive sedimentation occurred at $\sim 0.6 \mathrm{ka}$. However, the sediment sequence for a tributary valley records only sedimentation events at $\sim 1.4$ and $\sim 0.7 \mathrm{ka}$. Tipping et al. (1999) interpreted the alluvial-peat sequence in upper Annandale as a series of sedimentation episodes separated by periods of relative quiescence, but they also emphasized the asynchronicity of events recorded within the basin. Their findings suggest that the history of Holocene alluviation may differ within a single catchment or across a single floodplain, and hence may not be fully captured by the stratigraphy of individual sites.

Similar complexity is highlighted in a study by Tipping (1995b) of terraces flanking the Kirtle Water, which drains a $110 \mathrm{~km}^{2}$ catchment that terminates at the Solway Firth. The uppermost of five terraces (T1) is probably of Lateglacial age, and T2 (KB II and PG II in Fig. 23) appears to represent floodplain aggradation after $\sim 10.4 \mathrm{cal}{ }^{14} \mathrm{C}$ ka and incision after $\sim 5.4{ }^{14} \mathrm{C}$ ka. T3 is undated. Tree growth dated to $\sim 2.6 \mathrm{cal}{ }^{14} \mathrm{C} \mathrm{ka}$ in one reach and peat accumulation in another between $\sim 2.2$ and $\sim 1.5 \mathrm{cal}{ }^{14} \mathrm{C} \mathrm{ka}$ was succeeded by diachronous floodplain aggradation to the level of T4 (KB IV and PG IV), followed by incision after $\sim 0.7 \mathrm{cal}{ }^{14} \mathrm{C} \mathrm{ka}$; from historical evidence the lowest terrace (T5) appears to represent the floodplain in $\mathrm{AD} \sim 1750$. Tipping struggled to assign causality to these changes: he attributed the cycle of aggradation and incision represented by T2 to early Holocene 'climatic oscillations' and the diachronous aggradation represented by T4 to 'a spatially discrete anthropogenic cause'. It is possible that the latter reflects reduced slope stability following major woodland clearance at $\sim 2.0 \mathrm{cal}{ }^{14} \mathrm{C}$ ka. 
The evidence from these sites in southern Scotland suggests that floodplain stability or aggradation was typical of much of the early to mid Holocene, but that subsequent alluvial history was catchment- or even reach-specific. The evidence relating late Holocene alluviation or incision to prehistoric land-use change (particularly woodland clearance) through coincidence of timing is suggestive but remains tantalizingly inconclusive.

4.4.1.3. The Midland Valley. A study by Tipping et al. (2008) of the alluvial deposits of the River Kelvin between Kirkintilloch and Kilsyth suggests that the Holocene alluvial history of the comparatively low-energy river systems of the Midland Valley (Central Lowlands) differs markedly from that of their upland counterparts. Multiple cores retrieved from four transects across the River Kelvin floodplain revealed up to $\sim 3.5 \mathrm{~m}$ of mainly fine-grained sediments, locally underlain by peat up to $\sim 1.5 \mathrm{~m}$ thick. Four radiocarbon dates from the top of the peat range from $8.8-8.6$ to $6.7-6.6 \mathrm{cal}{ }^{14} \mathrm{C}$ ka implying subsequent net floodplain aggradation, and eight dates from the base of the peat range from $11.7-11.4$ to $5.8-5.7 \mathrm{cal}{ }^{14} \mathrm{C}$ ka implying floodplain aggradation during the early Holocene. A Roman fortification, the Antonine Wall, cuts across the present flood plain, implying that aggradation must have ceased by the time of its construction in AD 140. Tipping et al. (2008) concluded that the uppermost 4-6 $\mathrm{m}$ of alluvial deposits accumulated during the early and middle Holocene, and that floodplain aggradation ceased at least 2000 years ago, and probably much earlier.

4.4.2. Holocene alluvial fans. Holocene alluvial fans are common in major valleys in upland Scotland. Some are low-gradient 'confluence' fans that are inset within Lateglacial fans at the mouths of major tributaries, as at the Feshie-Spey confluence (Werritty \& McEwen 1997). The majority, however, are small fans, often located on Holocene floodplain terraces, at the mouths of steep tributary valleys or gully systems. Such fans represent episodic erosion of driftmantled slopes by a combination of flood torrents and, in some cases, channelized debris flows.

For small valley-side fans the timing of episodes of fan accumulation therefore represents that of destabilization of slopes in the fan catchment, and can be determined by radiocarbon dating of organic material buried under or interbedded with fan deposits. Most small fans appear to have accumulated as a result of a small number of exceptional flood events. This has been demonstrated for a fan in the Edendon valley (Fig. 24), where dating of the top and base of peat horizons that extend across the full width of the fan has shown that the fan accumulated on the underlying late Holocene terrace in just three depositional events at $\sim 2.2, \sim 2.0$ and $\sim 0.8$ cal ${ }^{14} \mathrm{C}$ ka (Ballantyne \& Whittington 1999). During these events sediment was stripped from the walls of the parent gully, ultimately building a fan with a volume of $\sim 6750 \mathrm{~m}^{3}$ that accumulated in just a few hours within an overall timescale of more than two millennia. Similarly, a larger $\left(\sim 125,000 \mathrm{~m}^{2}\right)$ fan that accumulated over peat after $\sim 3.8 \mathrm{cal}{ }^{14} \mathrm{C} \mathrm{ka}$ and continued to prograde until after $\sim 1.2 \mathrm{cal}{ }^{14} \mathrm{C}$ ka over a Holocene terrace in Gleann Licht (Kintail) was interpreted by Reid et al. (2003) as representing 12-15 discrete sedimentation episodes. A recent analogue for such episodic fan accumulation is provided by an exceptional flood event that resulted in deposition of a layer of coarse sediment on small fans in the Howgill Fells in NW England (Harvey 1986; Wells \& Harvey 1987).

Radiocarbon dates constraining the timing of valley-side fan deposition reveal a remarkable temporal focus. With a single questionable exception - a small fan or debris cone in Gleann Licht 
that probably represents episodic debris-flow deposition after $\sim 7.5 \mathrm{cal}{ }^{14} \mathrm{C} \mathrm{ka}$ (Reid et al. 2003) all dated fans appear to have been deposited after $\sim 4.0 \mathrm{ka}$ (Fig. 25). Moreover, there is no evidence that this temporal pattern reflects erosion of evidence for earlier Holocene fans, as earlier fan remnants are either absent or of demonstrably of Lateglacial age. This pattern is not confined to Scotland, as all of 37 radiocarbon ages obtained for alluvial fans in NW England also indicate fan accumulation (and thus gully erosion) after $4.0 \mathrm{ka}$ (Foster et al. 2008).

In addressing this phenomenon, Chiverrell et al. (2007) and Foster et al. (2008) have demonstrated that there is no link between the timing of enhanced gully erosion and periods of cooler or wetter climate identified from peat humification data, particularly as cooler or wetter shifts prior to $\sim 4.0 \mathrm{ka}$ do not appear to have produced gully erosion and concomitant fan formation. Amassing a wealth of historical, archaeological and palynological data, they argued that phases of enhanced gully erosion followed cycles of settlement expansion and land use change in upland areas. Woodland clearance, burning and grazing pressure probably represent the most important factors preconditioning drift-mantled slopes to erosion; they envisaged that such clearance lowered the threshold of stability of such slopes, rendering them more vulnerable to gully formation, incision and expansion during and probably after exceptional rainstorm events. For the Southern Uplands, they suggested that sporadic gullying events occurred during the Late Bronze to Iron Age $(\sim 4.0-2.0 \mathrm{ka})$, but that the most intensive periods of gullying occurred at $\sim 1.3-1.1 \mathrm{ka}$ (AD 700-900), 0.9-0.7 ka (AD 1100-1300) after 0.55-0.45 ka (AD 1450-1550), with little evidence of activity over the past $\sim 150$ years. This analysis is based on a limited number of radiocarbon ages from sites in the Southern Uplands (Fig. 25) but is strongly supported by the dating evidence for fans in NW England, and indeed is consistent with the timing of depositional episodes on three Highland fans (Edendon valley, Glen Etive and Gleann Licht) and that of valley-fill deposition at Dunglass in SE Scotland (Tipping 2007).

The arguments and data presented by Chiverrell et al. (2007) and Foster et al. (2008) are compelling, but evidence from individual sites suggests a more complex picture. In Glen Etive, there is palynological evidence of clearance for agriculture prior to fan formation (Brazier et al. 1988), but elsewhere such evidence is lacking. For the Hopecarton Burn fan, which rests on a terrace of the River Tweed, Tipping \& Halliday (1994) adduced from pollen evidence that no woodland clearance occurred in the fan catchment prior to fan deposition at $\sim 0.9 \mathrm{ka}$, and there is a similar lack of palynological evidence for any form of anthropogenic landscape change prior any of the three storm runoff events that formed the Edendon fan between $\sim 2.2$ and $\sim 0.8 \mathrm{ka}$ (Ballantyne \& Whittington 1999). It is possible that pedogenesis throughout the Holocene may have progressively reduced the stability of drift-mantled slopes, as argued by Brooks et al. (1995), and it seems likely that early Holocene paraglacial fans accumulated in the Highlands (Brazier 1987) but are not associated with burial of organic material suitable for radiocarbon dating. The work of Chiverrell et al. (2007) and Foster et al. (2008) has provided valuable insights into the history of Holocene alluvial fans in Scotland and NW England, but a fuller picture may yet emerge.

4.4.3. Bedrock channels. An interesting recent development has been research on the postglacial evolution of bedrock channels in Scottish rivers. Particular attention has been focused on knickpoint retreat initiated by glacio-isostatic uplift and consequent fall of relative sea level, which lowered the base level for tidewater-terminating rivers. For 14 such rivers in E Scotland, 
Bishop et al. (2005) showed that the retreat distance of knickpoints initiated by sea-level fall from the postglacial marine limit ranges from $76 \mathrm{~m}$ for the smallest catchment to $21.5 \mathrm{~km}$ for the largest. They found that the distance of knickpoint retreat exhibits a strong positive correlation with catchment area, implying that retreat rate has been essentially determined by stream discharge. A similar conclusion was reached by Castillo et al. (2013) from a study of knickpoint retreat from the marine limit on the Isle of Jura. This study showed that the power law relationship between knickpoint retreat distance and catchment area for streams flowing westward across scarp slopes is almost identical to that for those flowing eastward across dip slopes, implying that the rate of knickpoint recession has been insensitive to underlying structural trends on (quartzite) rocks of uniform resistance.

Changes in the rate of postglacial knickpoint retreat have been reconstructed by Jansen et al. (2011) through cosmogenic ${ }^{10} \mathrm{Be}$ exposure dating of strath terraces (bedrock channel remnants elevated above the present stream channel) for four rivers draining into Loch Linnhe. They found that downcutting of bedrock channels due to lowering of base level (relative sea level) has occurred through both knickpoint retreat and diffusive transport-limited river incision. Strath exposure ages show that channel incision commenced at $\sim 11.5 \mathrm{ka}$, shortly after retreat of LLR glaciers, and that knickpoints subsequently retreated up-channel through bedrock detachment. The exposure ages also demonstrate that the rate of knickpoint retreat in all four catchments was greatest in the early to mid Holocene and has since declined, approximately exponentially, by two orders of magnitude. This radical decline in knickpoint retreat rate they attributed to progressive diminution of paraglacial sediment supply to these rivers, as coarse sediment forms the 'tools' by which rivers both detach bedrock at knickpoints and incise bedrock channels.

Other studies have focused on controls on postglacial channel morphology. For bedrock rivers draining the W Grampians, Jansen et al. (2010) found that channels underlain by the most resistant lithology (quartzite) are associated with channel steepening by a factor of 1.5-6.0 with typically only slight channel narrowing, and that bedrock channel width tends to increase nonlinearly with catchment area. They suggested that knickpoints on quartzite outcrops may be inherited from steps in glacial troughs produced by differential glacial erosion, and that such outcrops form pinning points that have slowed knickpoint recession. The role of differential glacial erosion in conditioning the long profiles of rivers in the Highlands has also been emphasized by Whitbread et al. (2015), who studied the effects of substrate, sediment and slope controls on the channel geometry of both bedrock and alluvial reaches of three rivers in NW Scotland. Their measurements also showed that reach-averaged channel width (and to a lesser extent channel depth) scale with upstream catchment area and thus discharge. Their data also indicate that bank and bed materials have exercised secondary (mainly localised) controls on channel morphology, and that channel slope strongly governs the transition between bedrock and alluvial reaches due to its influence on sediment transport and bed cover. A study of channel reach morphology in upland tributaries of the Dee above Aboyne (Addy et al. 2011), has confirmed that channel geometry and morphology are adjusted to discharge, slope and the calibre of bed material. Their study also showed that many reaches do not fit readily into the bedrock, cascade, step-pool, plane-bed and pool-riffle continuum established for other environments, but that transitional, mixed alluvial-bedrock and wandering channel reaches are common. From the strong scaling of bedrock channel widths with upstream catchment area, Whitbread et al. (2015) 
inferred that postglacial fluvial erosion has been sufficient to reconfigure bedrock channel morphology in the $12-15 \mathrm{ka}$ since deglaciation, implying that although ancestral bedrock channels were probably cut by glacial meltwater streams, postglacial fluvial erosion has resulted in progressive adaptation of channels to Holocene discharge and sediment supply regimes.

4.4.4. Recent behaviour of fluvial systems. Research on the recent behaviour of fluvial systems has adopted three overlapping approaches: (1) studies of the geomorphological impact of extreme flood events; (2) use of maps and aerial photographs to reconstruct historical channel planform changes (Fig. 26); and (3) field investigation of short-term channel changes and sediment transport. McEwen (1997) and Werritty \& McEwen (1997) have summarised earlier work on these topics. Werritty \& Hoey (2003) have classified Scottish rivers into eleven types (Table 1) that form a useful basis for discussion. Large catchments such as those of the Spey, Dee and Tweed contain most of the categories identified in Table 1, with headwater streams and mountain torrents feeding meandering, locally braided and wandering gravel-bed rivers on floodplains where channels are often locally constrained either naturally, by bedrock or Lateglacial terraces, or artificially by flood embankments, bank reinforcement or resectioning.

Perhaps inevitably, most research has focused on sites that exhibit the greatest recent activity, particularly categories 1-4 in Table 1 . Many of these are located on what Werritty \& Leys (2001) termed 'piedmont zones': high-energy, low threshold fluvial environments located where steep mountain streams join the floodplains of major rivers. In such areas, exceptional flood events play a major role in redistributing coarse sediment and remodelling channel planform. The effects of the largest recorded historic flood in the UK, the 'Muckle Spate' of 1829 in the Moray region of NE Scotland were documented in detail by Lauder (1830). From his account and field evidence, McEwen \& Werritty (2007) retrodicted an approximate peak discharge (up to $\sim 1500 \mathrm{~m}^{3} \mathrm{~s}^{-1}$ on the main stem of the River Findhorn) and its effects within the Findhorn catchment. Within bedrock or mixed bedrock-alluvial reaches the flood appears to have had limited impact, but within unconfined alluvial reaches, particularly near the mouth of the river, it caused widespread bank erosion, excavated new channels and deposited sheets of sand and gravel over adjacent low ground, leading to destruction of property, despoliation of agricultural land and destitution of the local populace. The flashy response to convectional rainstorms of rivers draining steep upland catchments also has a marked (if localised) impact, causing bank erosion, channel scour and redistribution of sediment over downstream fans and low terraces (Acreman 1983, 1991). The best-documented case of the geomorphic impacts of flash flooding in a mountain torrent is that for the Allt Mór, which drains a steep catchment in the NW Cairngorms (McEwen \& Werritty 1988). Though the upper, boulder-floored reaches of the Allt Mór experienced limited modification, entrenched reaches underwent extensive erosion and the alluvial fan at its downstream confluence experienced channel avulsion and development of two new channels, one of which now carries most of the flow. Similar flood impacts have been recorded on piedmont zone rivers: on the Dorback Burn, a tributary of the River Nethy, repeated surveys showed that extreme rainstorm events had completely remodelled the active channel (Werritty 1984), whilst detailed research on a braided reach of the River Feshie revealed that major flood events have tended to obliterate the former channel pattern and replace it with a chaotic braided system with numerous unstable bars and channels (Werritty \& Ferguson 1980). Studies of channel change on the River Feshie using sequential aerial photographs and high- 
resolution digital elevation models have confirmed that channels within alluvial reaches are intrinsically unstable, with evidence of flow reorganisation, channel avulsion, lateral channel switching, erosion of sediment from bars and channels and deposition of sediment in channels operating over annual to decadal timescales (Rumsby et al. 2001, 2008). Modification of channel patterns during floods is probably less pronounced in lowland rivers, but these are not exempt: a flood with an estimated 70-year return period on the lower Tay in 1990 eroded two new channels along the routes of palaeochannels (Gilvear \& Harrison 1991).

As the above examples illustrate, major flood events trigger bed mobility, sediment redistribution, avulsion, bar migration and bank erosion, particularly on unconfined reaches of braided and wandering gravel-bed rivers. There is evidence, though, that post-flood floodplains are metastable, being subject to more gradual modification by lower flows. On the River Feshie, there is evidence of progressive replacement of post-flood braidplains by sinuous single-thread channels that locally divide around medial bars (Werritty \& Ferguson 1980), leading Ferguson \& Werritty (1983) to propose that the Feshie and kindred wandering gravel-bed rivers are subject to divergent meandering and braiding tendencies that do not permit evolution towards a steady stable channel configuration. This appears to be supported studies of channel pattern changes on the River Feshie (Rumsby et al. 2001) and the River Dee, where an increased frequency of moderate flood events has been associated with an increased propensity for channel subdivision (McEwen 1989). Channel gradient plays a key role in determining the dominance of braiding or meandering channels. Studies on the lower Allt Dubhaig (Drumochter), have demonstrated that a progressive reduction in channel gradient is accompanied by gradual replacement of a nearbraided planform by a meandering channel then, on the lowest gradients, by a stable sinuous channel (Ferguson \& Ashworth 1991). Repeated downstream sequences of channel reach type are common in Highland glens and upland tributaries where individual alluvial reaches are graded to local base levels represented by bedrock steps that reflect differential glacial erosion of valley floors (Whitbread et al. 2015), though the nature of such sequences is locally influenced by topographic controls (channel confinement) and coarse bed materials derived from glacigenic deposits (Addy et al. 2014).

The question of stability of piedmont rivers in upland Scotland has been addressed by Werritty \& Leys (2001) through reconstruction of the channel planforms of nine rivers based on maps and aerial photographs covering the period since the mid-18th century. Although all these rivers exhibited changes in planform in response to major floods and inter-flood adjustment (manifest in lateral channel shift, and changes in active channel area and channel sinuosity), none exhibited a systematic change in state, apart from one affected by an artificial rise in base level. The implication is that over the past 200-250 years there has been an approximate balance between formative discharge regime, channel gradient and sediment supply; such rivers are reworking floodplain surfaces, but have exhibited no intrinsic tendency for net floodplain aggradation or incision.

Similar historical evidence has been used to illustrate the nature of channel pattern changes in a range of fluvial environments. For the lower Spey, steepening of the valley floor by glacioisostatic uplift has resulted in extensive development of braided channels. Lewin \& Weir (1977) calculated that the lower Spey had reworked about $50 \%$ of its floodplain since 1880, and mapping by Riddell \& Fuller (1995) shows that near the coast the main channel of the Spey shifted 
laterally by up to $400 \mathrm{~m}$ between 1968 and 1992. Avulsion of the main channel of the River Coe above Loch Achtriochan has caused it to shift laterally by over $200 \mathrm{~m}$ between 1962 and 1988 (McEwen 1994; Fig. 27). Studies of channel planform change of the River Tay since 1783 have shown that some reaches experienced little change over 200 years, though steeper reaches experienced lateral channel migration of up a kilometre (Gilvear \& Winterbottom 1992). Both the Tay and its tributary, the Tummel (Fig. 26a) have shown a tendency to channel narrowing since the mid-18th century, a trend attributed by Winterbottom (2000) to flood embankment construction after the mid-19th century and subsequent flow regulation. Over a similar timescale, meandering rivers flowing over low-gradient floodplains in lowland areas have exhibited a tendency for downstream meander migration, accompanied by increasing sinuosity until cutthrough of meander necks during floods isolates ox-bow lakes in abandoned channels (Brazier et al. 1993; Fig. 26b). Increased regulation of lowland rivers, however, means that most lowland meandering streams are now 'inactive' (category 6 in Table 1) so that recent channel changes have been limited.

\section{Discussion}

Although the distinctive signature of recurrent Pleistocene glaciations remains the dominant feature in much of the Scottish landscape, a wide range of postglacial geomorphological processes has resulted in extensive modification of the glacial landscape. Appreciation of the nature and effects of postglacial processes is a comparatively recent development. Whereas a vast literature on the glacial landforms and deposits of Scotland has accumulated over nearly two centuries, almost all research on postglacial landscape evolution outside the coastal zone belongs to the past three decades, and has engaged a comparatively small number of researchers. One consequence is that there are still major gaps in our understanding of this topic; another is that this remains a fertile area for future research. Some research priorities are briefly outlined below. 


\subsection{Lateglacial periglaciation}

As outlined above (section 3.1), much of our current understanding of Lateglacial periglaciation and permafrost development on low ground dates back to research carried out over 50 years ago when understanding of modern analogues was limited. We now have much greater understanding of the structural, sedimentological and micromorphological characteristics of relict periglacial phenomena such as ice-wedge pseudomorphs, relict sand wedges, involutions, fragipans and formerly permafrozen soils, and the palaeoenvironmental significance of such features (Ballantyne 2017). Moreover, Lateglacial periglacial features that occur elsewhere in the British Isles and NW Europe, such as loess and coversand deposits, thermokarst features, ground-ice depressions and active-layer detachment failures (e.g. Ballantyne \& Harris 1994; Isarin, 1997; Kasse et al. 2007; Andrieux et al. 2016; Murton \& Ballantyne 2017) have hitherto not been recorded in Scotland. The lack of recent research on lowland periglacial phenomena in Scotland suggests that such deposits and landforms may simply not been recognised. Given the abundance of exposures in superficial deposits (particularly gravel pits), the availability of satellite and airphoto imagery for detection of features such as polygonal crop marks and ground-ice depressions, improved techniques of soil micromorphological analyses and the availability of sediment dating techniques (principally OSL dating), there is potential for unravelling a more detailed history of Lateglacial periglaciation and permafrost than that summarised in section 3.1. The most urgent question relates to the status of past permafrost during the YDS. Strategies for addressing this question include searching for permafrost indicators (relict frost wedges, thermal contraction crack polygons and ground-ice depressions) in YDS outwash deposits, and stratigraphic analyses of Lateglacial deposits to elucidate the history of permafrost aggradation and degradation .

\subsection{Slope failures and debris flows}

5.2.1. Rock-slope failures. Although TCN dating of catastrophic RSFs has advanced our understanding of their timing and causes (Ballantyne et al. 2014a), many of the largest RSFs in both the Highlands and Southern Uplands are deep-seated gravitational slope deformations (Jarman 2006) of unknown age and uncertain cause. TCN dating of the failure planes or antiscarps associated with rock-slope deformations (Hippolyte et al. 2012; Zerathe et al. 2014) offers an opportunity to determine whether such features are essentially Lateglacial paraglacial features that represent short-term rock mass response to differential deglacial unloading, or whether they have developed over longer timescales. Moreover, deglacial unloading inevitably results in reorientation of the principal stress field at depth; this can potentially be modelled for particular sites where the underlying structural configuration is known (e.g. Gugliemi \& Cappa 2010) to identify the depth at which deformation is likely to have occurred. Development of such analyses also has the potential to help identify risk of future catastrophic failure.

A related question is the role of palaeoseismicity in triggering RSFs. Though the timing of most dated catastrophic RSFs is consistent with coseismic release due to crustal-uplift-induced Lateglacial earthquakes (Ballantyne et al. 2014a), the timing of major seismic events during the Lateglacial remains to be confirmed. TCN dating of fault scarps (such as those along the Loch Hourn fault) to confirm a temporal connection between palaeoseismicity and Lateglacial RSFs (cf. Sanchez et al. 2010) is therefore a research priority. Moreover, seismic acceleration increases 
towards slope crests and mountain ridges (Meunier et al. 2008; Hovius \& Meunier 2012) and may be responsible for the numerous small-scale scarp collapses that occur in such locations, so TCN dating of a sample of such scarps allied to back-analysis of pre-failure scarp configuration may provide potential confirmation of the role of palaeoseismicity in destabilizing rock slopes.

A further promising area of research involves using erratic boulders to establish the contribution of Lateglacial RSFs, now represented by debris-free scarps, to the large volume of sediment contained in LLR moraines, extending the work of Benn (1989), who showed that the volumes of lateral moraines are directly related to the occurrence of steep rock slopes in former glacier source areas. Such research is most likely to yield results on mountain terrain underlain by a variety of distinctive lithologies, such as the vicinity of the Moine Thrust Zone and adjacent Hebridean Craton in NW Scotland.

5.2.1 Debris-flow activity. Radiocarbon dating of buried palaeosols and peat layers has provided evidence for recurrent debris-flow activity over the last $\sim 7 \mathrm{ka}$ (Fig. 21), and there is some evidence for enhanced debris-flow activity during or shortly after deglaciation (Benn 1992; Bennett 1999) and in recent decades or centuries (Innes 1983; Brazier \& Ballantyne 1989; Ballantyne 1991). The record of dated debris flows is, however, spatially fragmented, and no terrestrial site preserves a full record of Lateglacial and Holocene debris flow activity. An alternative approach, developed by researchers in Norway (Sletten et al. 2003; Nielsen et al. 2016) is to identify episodes of past debris-flow activity represented by distinctive coarse minerogenic layers in cores recovered from lakes flanked by steep drift-mantled slopes, such as Loch Einich (Fig. 18), Loch More (Assynt) and Loch Damh (Torridon). Unlike terrestrial sites, lake basins potentially contain a complete record of major debris-flow events since deglaciation, and lake cores may therefore contain evidence for pulses of enhanced sediment delivery.

\subsection{Floodplain evolution}

As outlined in section 3.4, there is widespread consensus that high-level river terraces in the Highlands (and probably the Southern Uplands) are of Lateglacial age, and that most represent the remnants of proglacial sandar deposited by glacial rivers as the last ice sheet retreated (Robertson-Rintoul 1986; Maizels \& Aitken 1991; Russell 1995; Tipping 1995b; Aitken 1998; Marren 2001; section 3.4.1). Conversely, the available dating evidence suggests that most lowlevel terraces are of late Holocene age (Sections 4.4.1.1 and 4.4.1.2). There is therefore a temporal hiatus of $\sim 10 \mathrm{ka}$ in our understanding of floodplain evolution in upland areas. Vandenberghe $(2003,2008)$ has proposed that floodplain incision mainly occurred during periods of climatic transition, and that incision during cold-to-temperate transitions (such as the Lateglacial to Holocene transition) resulted from diminished sediment supply as vegetation cover became widespread, limiting sediment entrainment. The applicability of this model in the Highlands may potentially be tested through comparison of terrace sequences immediately inside and outside the limits of LLR valley glaciers to establish whether river incision through outwash deposits was accomplished before the end of the Lateglacial, or continued into the early Holocene. Similarly, studies of channel planform on terraces inside and outside the limits of LLR glaciers may throw light on changes in river regime; many lowland rivers in NW Europe

underwent a change from braided to single-thread meandering channels in the early Holocene 
(e.g. Brown et al. 1994; Huisink 2000), and a similar change may be evident from palaeochannels preserved on terrace surfaces.

Particularly intriguing is the evidence for aggradation of floodplains in the late Holocene, as demonstrated by radiocarbon dating of organic material contained within the deposits underlying highest Holocene terrace (Section 4.4.1.1). Terrace exposures containing organic inclusions are not uncommon along eroding riverbanks in the Highlands, and the same terraces are often overlain by peat. It should therefore be possible to constrain the timing of the culmination of Holocene floodplain aggradation through radiocarbon dating of sub-terrace organic material and the base of the overlying peat, as reported for the Edendon Valley in the central Grampians (Ballantyne \& Whittington 1999). Such dating would establish the reality or otherwise of the 'Main Holocene Terrace' proposed by Ballantyne (2008), or establish whether patterns of Holocene floodplain aggradation were spatially asynchronous. Moreover, if the associated alluvial aggradation represents the progressive downvalley reworking of sediment derived from upstream valley fill, then it may be possible to detect downstream-younging of the highest Holocene terrace on long alluvial reaches uninterrupted by bedrock steps (cf. Church et al. 1989; Church \& Slaymaker 1989; Harbor \& Warburton 1993).

\subsection{Lacustrine sedimentation}

Terminal sediment sinks for fluvially-transported sediment include valley fills, lakes, fjords and estuaries (Fig. 4). Of these, sediments that have accumulated in lake basins have the greatest potential for establishing changes in the rate of minerogenic sediment input and thus changes in the rate of sediment evacuation from contributory catchments and adjacent hillslopes. Research in various deglaciated terrains has employed geophysical surveys and construction of age-depth profiles (based on radiocarbon dating of organic matter in sediment cores) to retrodict changes in minerogenic sedimentation rates since deglaciation Such studies have generally demonstrated much higher sedimentation rates during and immediately after deglaciation (Ballantyne 2002a, pp. 1974-1977). Although cores have been recovered from the floors of several Scottish lochs to reconstruct patterns of postglacial vegetation change, primarily through pollen through analyses and radiocarbon dating of gyttja (organic mud) deposits (e.g. Pennington et al. 1972), such lochs have often been selected to minimise the contribution of minerogenic sediment settling from suspension, and variations in non-organic sediment input have not been assessed in detail. There is therefore unrealised potential for targeted coring of Scottish lacustrine sediments to establish changes in the rates of minerogenic sediment accumulation throughout the Holocene and possibly Lateglacial, and thereby identifying the duration of enhanced paraglacial sedimentation, the timing and frequency of extreme rainstorm events leading to enhanced sediment accumulation, and the chronology and impacts of late Holocene anthropogenic land cover modification within contributing catchments. Foster et al. (2008) have demonstrated the potential of this approach for recent (post AD 1600) sediment accumulation in the Loch of the Lowes - St Mary's Loch basin in the Southern Uplands, but there is considerable potential for extending it over a much longer timescale. Multi-proxy analyses of multiple cores recovered from lochs have the potential to provide a template for the general pattern of geomorphological change throughout the Holocene or longer, a template that is unlikely to be derived from site-specific studies of particular landforms or sediment exposures. 


\section{Conclusion}

As this brief review demonstrates, the past 30 years have witnessed major advances in our understanding of the postglacial landscape evolution in Scotland, but progress has been uneven. Whereas, for example, we now know much more about the role of rock-slope failure, debris-flow activity and the evolution of bedrock channels, progress in other areas of research (such as the effects of Lateglacial periglaciation) has stalled.

Unquestionably, most dramatic modifications to the postglacial landscape occurred during the Lateglacial period, when mountainsides crumbled, collapsed or shifted, permafrost underlay the ground and thick glacifluvial and alluvial deposits accumulated in valleys. In part these changes reflect the pronounced and rapid changes in climate during this period (Fig. 2), and in part they are due to the metastability of recently-deglaciated terrain, manifest in paraglacial rockslope failures and the release, reworking and redeposition of glacigenic sediment over timescales of decades to millennia. There is, however, limited evidence for a consistent trajectory of subsequent (Holocene) landscape evolution for all of Scotland or even the major regions within Scotland. This situation suggests that the 'noise' introduced by local circumstances (extreme rainstorms or floods; changes in base level; anthropogenic effects such as woodland clearance, burning, tillage, and overgrazing) transcends any longer-term regional effects due to climate change or progressive reduction in the rate of paraglacial landscape modification.

Diminution of the role of some paraglacial processes is evident in many upland areas, where talus accumulations, debris cones, alluvial fans and floodplains that accumulated after deglaciation are essentially relict sediment stores that have experienced subsequent erosion and incision. Conversely, vast quantities of glacigenic sediment still drape hillslopes and underlie floodplains, and there is some evidence for delayed reworking of such sediment by translational landslides, debris flows and rivers; many late Holocene alluvial fans and debris cones, for example, are composed of reworked glacial deposits (e.g. Brazier \& Ballantyne 1989; Ballantyne \& Whittington 1999; Foster et al. 2008). A particularly interesting question is whether the evidence for late Holocene floodplain aggradation in upland areas is due to rivers cannibalising upstream 'primary' paraglacial sediment stores (particularly alluvial deposits), an effect noted in other deglaciated environments (Church et al. 1989; Church \& Slaymaker 1989; Harbor \& Warburton 1993; Ballantyne 2002a). Such 'secondary' paraglacial sediment reworking (Fig. 4) potentially extends the period of paraglacial landscape modification long into the future, suggesting that some components of landscape change are still conditioned by past glaciation and deglaciation. It may be useful to conceptualise paraglacial effects not simply in terms of an overall decline in sediment release and reworking, but in terms of 'paraglacial succession', whereby some sediment stores continue to experience net accumulation even as others experience net erosion (Ballantyne 2003a).

One impediment to understanding the overall trajectory of postglacial landscape change is that much of the research cited in this review has been essentially site-specific and inductive, raising questions regarding the representativeness of the findings. Numerous geomorphologists, for example, have been mesmerised by the terraces, braided reaches and rapid channel change of the River Feshie, but the braided Feshie is arguably atypical of Highland rivers. Although such site-specific research has unquestionably provided telling insights into the nature of postglacial 
landform evolution, the most persuasive research results are often those arising from broader, hypothesis-generated studies. These include, inter alia, research on talus evolution and catastrophic rock-slope failures (Hinchliffe \& Ballantyne 2009; Ballantyne et al. 2014a), upland aeolian sediments (Morrocco et al. 2007), the relationship between floodplain or fan aggradation and prehistoric settlement (Tipping 1992; Tipping et al. 1999; Foster et al. 2008), the evolution of bedrock channels (Bishop 2005; Jansen et al. 2011; Whitbread et al. 2015) and the recent behaviour of fluvial systems (Werritty \& Leys 2011).

Such systematic studies provide templates for future research on the trajectory of postglacial landscape change. We now have at our disposal an impressive arsenal of powerful geochronological, geophysical, sedimentological, remote-sensing and survey techniques (and a much greater understanding of geomorphological processes and the sedimentary record) than was the case three decades ago. The key to future progress is to develop further hypothesis-based research designed to improve our understanding of the overall pattern and trend of landscape changes. Several approaches have been suggested in the discussion above (section 5). Despite the recent advances documented in this review, much remains to be learnt about the evolution of the Scottish landscape across the millennia that have elapsed since the retreat of the last ice sheet.

\section{Acknowledgements}

I thank Graeme Sandeman for his skill and patience in preparing the figures, Peter Wilson and an anonymous reviewer for insightful comments, and John Gordon for thorough copy-editing of the manuscript.

\section{References}

Acreman, M. C. 1983. The significance of the flood of September 1981 on the Ardessie Burn, Wester Ross. Scottish Geographical Magazine 100, 37-49.

Acreman, M. C. 1991. The flood of July 25th 1983 on the Hermitage Water, Roxburghshire. Scottish Geographical Magazine 107, 170-178.

Addy, S., Soulsby, C., Hartley, A. J. \& Tetzlaff, D. 2011. Characterization of channel reach morphology and associated controls in deglaciated montane catchments in the Cairngorms, Scotland. Geomorphology 132, 176-186.

Addy, S., Soulsby, C. \& Hartley, A. J. 2014. Controls on the distribution of channel reach morphology in selectively glaciated catchments. Geomorphology 211, 121-133.

Aitken, J. F. 1990. Glaciolacustrine deposits in Glen Nochty, Grampian Region, Scotland, UK. Quaternary Newsletter 60, 13-20.

Aitken, J. F. 1995. Lithofacies and depositional history of a Late Devensian ice-contact deltaic complex, northeast Scotland. Sedimentary Geology 99, 111-130.

Aitken, J. F. 1998. Sedimentology of Late Devensian glaciofluvial outwash in the Don Valley, Grampian Region. Scottish Journal of Geology 34, 97-117.

Andrieux, E., Bertran, P. \& Saito, K. 2016. Spatial analysis of French Pleistocene permafrost by a GIS database. Permafrost and Periglacial Processes 27, 17-30. 
Atkinson, T. C., Briffa, K. R. \& Coope, G. R 1987. Seasonal temperatures in Britain during the past 22,000 years, reconstructed using beetle remains. Nature 325, 587-592.

Auton, C. A. 1990. The middle Findhorn valley. In Auton, C. A., Firth, C. R. \& Merritt, J. W. (eds) Beauly to Nairn: Field Guide, 74-96. Coventry: Quaternary Research Association.

Auton, C. A. \& Crofts, R. G. 1986. The sand and gravel resources of the country around Aberdeen, Grampian Region. British Geological Survey Mineral Assessment Report 146.

Balco, G., Stone J. O., Lifton, N. A. \& Dunai, T. J. 2008. A complete and easily accessible means of calculating surface exposure ages or erosion rates from ${ }^{10} \mathrm{Be}$ or ${ }^{26} \mathrm{Al}$ measurements. Quaternary Geochronology 3, 174-195.

Ballantyne, C. K. 1984. The Late Devensian periglaciation of upland Scotland. Quaternary Science Reviews 3, 311-343.

Ballantyne, C. K. 1985. Nivation landforms and snowpatch erosion on two massifs in the Northern Highlands of Scotland. Scottish Geographical Magazine 101, 40-49.

Ballantyne, C. K. 1986a. Nonsorted patterned ground on mountains in the Northern Highlands of Scotland. Biuletyn Peryglacjalny 30, 15-34.

Ballantyne, C. K. 1986b. Landslides and slope failures in Scotland: a review. Scottish Geographical Magazine 102, 134-150.

Ballantyne, C. K. 1986c. Late Flandrian solifluction on the Fannich Mountains, Ross-shire. Scottish Journal of Geology 22, 395-406.

Ballantyne, C. K. 1987. The present-day periglaciation of upland Britain. In Boardman, J. (ed.) Periglacial Processes and Landforms in Britain and Ireland, 113-116. Cambridge: Cambridge University Press.

Ballantyne, C. K. 1989. Avalanche impact landforms on Ben Nevis, Scotland. Scottish Geographical Magazine 105, 38-42.

Ballantyne, C. K. 1991. Late Holocene erosion in upland Britain: climatic deterioration or human influence? The Holocene 1, 81-85.

Ballantyne, C. K. 1994. The tors of the Cairngorms. Scottish Geographical Magazine 110, 5459.

Ballantyne, C. K. 1996. Formation of miniature sorted patterns by shallow ground freezing: a field experiment. Permafrost and Periglacial Processes 7, 409-424.

Ballantyne, C. K. 1997. The periglacial geomorphology of Scotland. In Gordon, J. E. (ed.) Reflections on the Ice Age in Scotland, 166-178. Glasgow: Scottish Association of Geography Teachers and Scottish Natural Heritage.

Ballantyne, C. K. 1998a. Age and significance of mountain-top detritus. Permafrost and Periglacial Processes 9, 327-345.

Ballantyne, C. K. 1998b. Aeolian deposits on a Scottish mountain summit: characteristics, provenance, history and significance. Earth Surface Processes and Landforms 23, 625-641.

Ballantyne, C. K. 2001a. The sorted stone stripes of Tinto Hill. Scottish Geographical Journal 117, 313-324. 
Ballantyne, C. K. 2001b. Measurement and theory of ploughing boulder movement. Permafrost and Periglacial Processes 12, 267-288.

Ballantyne, C. K. 2002a. Paraglacial geomorphology. Quaternary Science Reviews 21, 19352017.

Ballantyne, C. K. 2002b. A general model of paraglacial landscape response. The Holocene 12, 371-376.

Ballantyne, C. K. 2002c. Debris flow activity in the Scottish Highlands: temporal trends and wider implications for dating. Studia Geomorphologica Carpatho-Balcanica 36, 7-27.

Ballantyne, C. K. 2003a. Paraglacial landform succession and sediment storage in deglaciated mountain valleys: theory and approaches to calibration. Zeitschrift für Geomorphologie, Supplementband 132, 1-18.

Ballantyne, C. K. 2003b. A Scottish sturzstrom: the Beinn Alligin rock avalanche. Scottish Geographical Journal 119, 159-167.

Ballantyne, C. K. 2007a. Trotternish Escarpment, Isle of Skye, Highland (NG450717NG 481 494). In Cooper, R. G. (ed.) Mass Movements in Great Britain. Geological Conservation Review Series 33, 196-204. Peterborough: Joint Nature Conservation Committee.

Ballantyne, C. K. 2007b. Coire Gabhail, Highland (NN 166 557). In Cooper, R. G. (ed.) Mass Movements in Great Britain. Geological Conservation Review Series 33, 132-136. Peterborough: Joint Nature Conservation Committee.

Ballantyne, C. K. 2008. After the ice: Holocene geomorphic activity in the Scottish Highlands. Scottish Geographical Journal 124, 8-52.

Ballantyne, C. K. 2010a. Extent and deglacial chronology of the last British-Irish Ice Sheet: implications of exposure dating using cosmogenic isotopes. Journal of Quaternary Science 25, $515-534$.

Ballantyne, C. K. 2010b. A general model of autochthonous blockfield evolution. Permafrost and Periglacial Processes 21, 289-300

Ballantyne, C. K. 2012. Chronology of glaciation and deglaciation during the Loch Lomond (Younger Dryas) Stade in the Scottish Highlands: implications of recalibrated ${ }^{10} \mathrm{Be}$ exposure ages. Boreas 41, 513-526.

Ballantyne, C. K. 2013a. Paraglacial geomorphology. In Elias, S. A. \& Mock, C. J. (eds) Encyclopedia of Quaternary Science, Second Edition, Volume 3, 553-565. Amsterdam: Elsevier.

Ballantyne, C. K. 2013b. Patterned Ground. In Elias, S. A. \& Mock, C. J. (eds) Encyclopedia of Quaternary Science, Second Edition, Volume 3, 452-463. Amsterdam: Elsevier.

Ballantyne, C. K. 2013c. Lateglacial rock-slope failures in the Scottish Highlands. Scottish Geographical Journal 129, 67-84.

Ballantyne, C. K. 2013d. A 35-year record of solifluction in a maritime periglacial environment. Permafrost and Periglacial Processes 24, 56-66.

Ballantyne, C. K. 2017. Periglacial Geomorphology. Chichester: Wiley. 
Ballantyne, C. K., Stone, J. O. \& Fifield, L. K. 1998. Cosmogenic Cl-36 dating of postglacial landsliding at the Storr, Isle of Skye, Scotland. The Holocene 8, 347-351.

Ballantyne, C. K., Schnabel, C. \& Xu, S. 2009. Exposure dating and reinterpretation of coarse debris accumulations ('rock glaciers') in the Cairngorm Mountains, Scotland. Journal of Quaternary Science 24, 19-31.

Ballantyne, C. K., Sandeman, G. F., Stone, J. O. \& Wilson, P. 2014a. Rock-slope failure following Late Pleistocene deglaciation on tectonically stable mountainous terrain. Quaternary Science Reviews 86, 144-157.

Ballantyne, C. K., Wilson, P., Gheorghiu, D. \& Rodés, À. 2014b. Enhanced rock-slope failure following ice-sheet deglaciation: timing and causes. Earth Surface Processes and Landforms 39, 900-913.

Ballantyne, C. K. \& Benn, D. I. 1994. Paraglacial slope adjustment and resedimentation in response to recent glacier retreat, Fåbergstølsbreen, Norway. Arctic and Alpine Research 26, 255-269.

Ballantyne, C. K. \& Benn, D. I. 1996. Paraglacial slope adjustment during recent deglaciation and its implications for slope evolution in formerly glaciated environments. In Anderson, M. G. \& Brooks, S. (eds) Advances in Hillslope Processes, 1173-1195. Chichester: Wiley.

Ballantyne C. K. \& Eckford, J. D. 1984. Characteristics and evolution of two relict talus slopes in Scotland. Scottish Geographical Magazine 100, 20-33.

Ballantyne, C. K. \& Harris, C. 1994. The Periglaciation of Great Britain. Cambridge: Cambridge University Press, 330 pp.

Ballantyne, C. K. \& Kirkbride, M. P. 1986. The characteristics and significance of some Lateglacial protalus ramparts in upland Britain. Earth Surface Processes and Landforms 11, 659-671.

Ballantyne, C. K. \& Morrocco, S. M. 2006. The windblown sands of An Teallach. Scottish Geographical Journal, 122, 149-159.

Ballantyne, C. K. \& Small, D. 2018. The Last Scottish Ice Sheet. Earth and Environmental Science Transactions of the Royal Society of Edinburgh (This issue).

Ballantyne, C. K. \& Stone, J. O. 2004. The Beinn Alligin rock avalanche, NW Scotland: cosmogenic ${ }^{10} \mathrm{~B}$ e dating, interpretation and significance. The Holocene 14, 461-466.

Ballantyne, C. K. \& Stone, J. O. 2009. Rock-slope failure at Baosbheinn, Wester Ross, NW Scotland: age and interpretation. Scottish Journal of Geology 45, 177-181.

Ballantyne, C. K. \& Stone, J. O. 2012. Did large ice caps persist on low ground in north-west Scotland during the Lateglacial Interstade? Journal of Quaternary Science 27, 297-306.

Ballantyne, C.K. \& Stone, J. O. 2013. Timing and periodicity of paraglacial rock-slope failures in the Scottish Highlands, Geomorphology 186, 150-161.

Ballantyne, C. K. \& Whittington, G. W. 1987. Niveo-aeolian sand deposits on An Teallach, Wester Ross, Scotland. Transactions of the Royal Society of Edinburgh: Earth Sciences 78, $51-63$. 
Ballantyne, C. K. \& Whittington, G. W. 1999. Late Holocene alluvial fan formation and floodplain incision, Central Grampian Highlands, Scotland. Journal of Quaternary Science 14, 651-671.

Bateman, M. D. 1995. Thermoluminescence dating of the British coversand deposits. Quaternary Science Reviews 14, 791-798.

Bayfield, N. G. 1984. The dynamics of heather (Calluna vulgaris) stripes in the Cairngorm Mountains, Scotland. Journal of Ecology 72, 515-527.

Benedict, J. B. 1970. Downslope soil movement in a Colorado alpine region: rates, processes and climatic significance. Arctic and Alpine Research 2, 165-226.

Benn, D. I. 1989. Debris transport by Loch Lomond Readvance glaciers in northern Scotland: basin form and the within-valley asymmetry of lateral moraines. Journal of Quaternary Science 4, 243-254.

Benn, D. I. 1992. The genesis and significance of 'hummocky moraine': evidence from the Isle of Skye, Scotland. Quaternary Science Reviews 11, 781-79.

Bennett, M. R. 1999. Paraglacial and periglacial slope adjustment of a degraded lateral moraine in Glen Torridon. Scottish Journal of Geology 35, 79-83.

Birse, E. L. 1980. Suggested amendments to the world soil classification to accommodate Scottish aeolian and mountain soils. Journal of Soil Science 31, 117-124.

Bishop, P., Hoey, T. B., Jansen, J. D. \& Lexartza Artza, I. 2005. Knickpoint recession rate and catchment area: the case of uplifted rivers in Eastern Scotland. Earth Surface Processes and Landforms 30, 767-778.

Blundell, A. \& Barber, K. E. 2005. A 2800-year palaeoclimatic record from Tore Hill Moss, Strathspey, Scotland: the need for a multi-proxy approach to peat-based climatic reconstructions. Quaternary Science Reviews 24, 1261-1277.

Boston, C. M. \& Lukas, S. 2017. Evidence for restricted Loch Lomond Stadial plateau ice in Glen Turret and implications for the age of the Turret Fan. Proceedings of the Geologists' Association 128, 42-53.

Bradwell, T., Stoker, M. S., Golledge, N. R., Wilson, C. K., Merritt, J. W., Long, D., Everest, J. D., Hestvik, O. B., Stevenson, A. G., Hubbard, A. L., Finlayson, A. G. \& Mathers, H. E. 2008. The northern sector of the last British Ice Sheet: maximum extent and demise. EarthScience Reviews 88, 207-226.

Brazier, V. 1987. Late Quaternary alluvial fans, debris cones and talus cones in the Grampian Highlands, Scotland. Unpublished PhD Thesis, University of St Andrews.

Brazier, V., Whittington, G. W. \& Ballantyne, C. K. 1988. Holocene debris cone evolution in Glen Etive, western Grampian Highlands, Scotland. Earth Surface Processes and Landforms 13, 525-531.

Brazier, V., Kirkbride, M. P. \& Werritty, A. 1993. The River Clyde-Medwin meanders. Scottish Geographical Magazine 109, 45-59.

Brazier, V., Kirkbride, M. P. \& Gordon, J. E. 1998. Active ice-sheet deglaciation and icedammed lakes in the northern Cairngorm Mountains, Scotland. Boreas 27, 297-310. 
Brazier, V. \& Ballantyne, C. K. 1989. Late Holocene debris cone evolution in Glen Feshie, western Cairngorm Mountains, Scotland. Transactions of the Royal Society of Edinburgh: Earth Sciences 80, 17-24.

Briffa, K. R. \& Atkinson, T. C. 1997. Reconstructing Late-glacial and Holocene climates. In Hulme, M. \& Barrow, E. (eds) Climates of the British Isles: Present, Past and Future, 84-111. London: Routledge.

Bromley, G. R., Putnam, A. E., Rademaker, K. M., Lowell, T. V., Schaefer, J. M., Hall, B., Winckler, G., Birkel, S. D. \& Borns, H. W. 2014. Younger Dryas deglaciation of Scotland driven by warming summers. Proceedings of the National Academy of Sciences 111, 62156219.

Brooks, S. J., Matthews, I.P., Birks, H.H. \& Birks, H.J.B. 2012. High resolution Lateglacial and early-Holocene summer air temperature records from Scotland inferred from chironomid assemblages. Quaternary Science Reviews 41, 67-82.

Brooks, S. J. \& Birks, H. J. B. 2000. Chironomid-inferred late-glacial air temperatures at Whitrig Bog, south-east Scotland. Journal of Quaternary Science 15, 759-764.

Brooks, S. M., Anderson, M. G. \& Collinson, A. J. C. 1995. Modelling the role of climate, vegetation and pedogenesis in shallow translational hillslope failure. Earth Surface Processes and Landforms 20, 231-242.

Brown, A. G., Keough, M. K., \& Rice, J. 1994. Floodplain evolution in the East Midlands, United Kingdom: the lateglacial and Flandrian alluvial record from the Soar and Nene Valleys. Philosophical Transactions of the Royal Society 348A, 261-293.

Bryant, R. H. \& Carpenter, C. P. 1987. Ramparted ground ice depressions in Britain and Ireland. In Boardman, J. (ed.) Periglacial Processes and Landforms in Britain and Ireland, 183-190. Cambridge: Cambridge University Press.

Castillo, M., Bishop, P. \& Jansen, J. D. 2013. Knickpoint retreat and transient bedrock channel morphology triggered by base-level fall in small bedrock river catchments: the case of the Isle of Jura, Scotland. Geomorphology 180-181, 1-9.

Cave, J. A. S. \& Ballantyne, C. K. 2016. Catastrophic rock-slope failures in NW Scotland: quantitative analysis and implications. Scottish Geographical Journal 132, 185-209.

Chandler, R. J., Kellaway, G. A., Skempton, A. W. \& Wyatt, R. J. 1976. Valley slope sections in Jurassic strata near Bath, Somerset. Philosophical Transactions of the Royal Society of London Series A 283, 527-556.

Chiverrell, R. C., Harvey, A. M. \& Foster, G. C. 2007. Hillslope gullying in the Solway Firth Morecambe Bay region, Great Britain: responses to human impact and/or climate deterioration? Geomorphology 84, 317-343.

Christiansen, H. H. 2004. Windpolished boulders and bedrock in the Scottish Highlands: evidence and implications of Late Devensian wind activity. Boreas 33, 82-94.

Church, M., Kellerhals, R. \& Day, T. J. 1989. Regional clastic sediment yield in British Columbia. Canadian Journal of Earth Sciences 26, 31-45.

Church, M. \& Slaymaker, O. 1989. Disequilibroum of Holocene sediment yield in glaciated British Columbia. Nature 337, 452-454. 
Church, M., Wolcott, J. \& Maizels, J. 1990. Palaeovelocity: a parsimonious proposal. Earth Surface Processes and Landforms 15, 475-480.

Clark, C. D., Hughes, A. L. C., Greenwood, S. L., Jordan, C. \& Sejrup, H. P. 2012. Pattern and timing of retreat of the last British-Irish Ice Sheet. Quaternary Science Reviews 44, 112-146.

Connell, E. R. \& Hall, A. M. 1987. The periglacial history of Buchan, north east Scotland. In Boardman, J. (ed.) Periglacial Processes and Landforms in Britain and Ireland, 277-285. Cambridge: Cambridge University Press.

Cornish, R. 2017. The gravel fans of upper Glen Roy, Lochaber, Scotland: their importance for understanding glacial, proglacial and glaciolacustrine dynamics during the Younger Dryas cold period in an Atlantic margin setting. Proceedings of the Geologists' Association 128, 83109.

Curry, A. M. 1999a. Paraglacial modification of drift-mantled hillslopes. Unpublished PhD thesis, University of St Andrews.

Curry, A. M. 1999b. Paraglacial modification of slope form. Earth Surface Processes and Landforms 24, 1213-1228.

Curry, A. M. 2000a. Holocene reworking of drift-mantled hillslopes in the Scottish Highlands. Journal of Quaternary Science 15, 529-541.

Curry, A. M. 2000b. Holocene reworking of drift-mantled hillslopes in Glen Docherty, Northwest Highlands, Scotland. The Holocene 10, 509-518.

Curry, A. M. \& Morris, C. J. (2004) Lateglacial and Holocene talus slope development and rockwall retreat on Mynydd Du, UK. Geomorphology 58, 85-106.

Davenport, C. A. \& Ringrose, P. S. 1987. Deformation of Scottish Quaternary sediment sequences by strong earthquake motions. Geological Society, London, Special Publications, 29, 299-314.

Dawson, A. G. 2009. So Foul and Fair a Day: a History of Scotland's Weather and Climate. Edinburgh: Birlinn, 230 pp.

Densmore, A. L. \& Hovius, N. 2000. Topographic fingerprints of bedrock landslides. Geology 28, 371-374.

Dickson, J. H., Jardine, W. G. \& Price, R. J. 1976. Three late-Devensian sites in west-central Scotland. Nature 262, 43-44.

Douglas, T. D. \& Harrison, S. 1987. Late Devensian periglacial slope deposits in the Cheviot Hills. In Boardman, J. (ed.) Periglacial Processes and Landforms in Britain and Ireland, 237244. Cambridge: Cambridge University Press.

Dykes, A. P. \& Warburton, J. 2008. Characteristics of the Shetland Islands (UK) peat slides of September 2003. Landslides 5, 213-226.

Everest, J. D. \& Kubik, P. W. 2006. The deglaciation of eastern Scotland: cosmogenic ${ }^{10} \mathrm{Be}$ evidence for a Lateglacial stillstand. Journal of Quaternary Science 21, 95-104.

Fabel, D., Ballantyne, C. K. \& Xu, S. 2012. Trimlines, blockfields, mountain-top erratics and the vertical dimensions of the last British-Irish Ice Sheet in NW Scotland. Quaternary Science Reviews, 55, 91-102. 
Ferguson, R. I. \& Ashworth, P. 1991. Slope-induced changes in channel character along a gravelbed stream: the Allt Dubhaig, Scotland. Earth Surface Processes and Landforms 16, 65-82.

Ferguson, R. I. \& Werritty, A. 1983. Bar development and channel changes in the gravelly River Feshie. International Association of Sedimentologists, Special Publication 6, 181-193.

Finlayson, A., Golledge, N., Bradwell, T. \& Fabel, D. 2011. Evolution of a Lateglacial mountain icecap in northern Scotland. Boreas 40, 536-554.

Firth, C. R. \& Stewart, I. S. 2000. Postglacial tectonics of the Scottish glacio-isostatic uplift centre. Quaternary Science Reviews 19, 1469-1493.

FitzPatrick, E. A. 1956. An indurated soil horizon formed by permafrost. Journal of Soil Science 7, 248-254.

FitzPatrick, E. A. 1969. Some aspects of soil evolution in north-east Scotland. Soil Science 107, 403-408.

FitzPatrick E. A. 1987. Periglacial features in the soils of north east Scotland. In Boardman, J. (ed.) Periglacial Processes and Landforms in Britain and Ireland, 153-162. Cambridge: Cambridge University Press.

Foster, G. C., Chiverrell, R. C., Harvey, A. M., Dearing, J. A. \& Dunsford, H. 2008. Catchment hydro-geomorphological responses to environmental change in the Southern Uplands of Scotland. The Holocene 18, 935-950.

Foulds, S. A. \& Macklin, M. G. 2006. Holocene land-use change and its impact on river basin dynamics in Great Britain and Ireland. Progress in Physical Geography 30, 589-604.

Galloway, R. W. 1961. Ice wedges and involutions in Scotland. Biuletyn Peryglacjalny 10, 169193.

Gemmell, A. M. D. \& Ralston, I. B. M. 1984. Some recent discoveries of ice-wedge cast networks in north-east Scotland. Scottish Journal of Geology 20, 115-118.

Gilvear, D. J. \& Harrison, D. J. 1991. Channel change and the significance of floodplain stratigraphy: 1990 flood event, Lower River Tay, Scotland. Earth Surface Processes and Landforms 16, 753-761.

Gilvear, D. J. \& Winterbottom, S. J. 1992. Channel change and flood events since 1783 on the regulated River Tay, Scotland: implications for flood hazard management. Regulated Rivers: Research and Management 7, 247-260.

Golledge, N. R. 2007. Sedimentology, stratigraphy, and glacier dynamics, western Scottish Highlands. Quaternary Research 68, 79-95.

Golledge, N. R. 2010. Glaciation of Scotland during the Younger Dryas Stadial: a review. Journal of Quaternary Science 25, 550-566.

Golledge, N. R., Hubbard, A. \& Sugden, D. E. 2008. High-resolution numerical simulation of Younger Dryas glaciation in Scotland. Quaternary Science Reviews 27, 888-904.

Goodfellow, B. W. 2007. Relict non-glacial surfaces in formerly glaciated landscapes. EarthScience Reviews 80, 47-73.

Goodfellow, B. W., Skelton, A., Martel, S. J., Stroeven, A. P., Jansson, K. N. \& Hättestrand, C. 2014. Controls on tor formation, Cairngorm Mountains, Scotland. Journal of Geophysical Research: Earth Surface 119, F002862. 
Gray, J. M. 1975. The Loch Lomond Readvance and contemporaneous sea levels in Loch Etive and neighbouring areas of western Scotland. Proceedings of the Geologists' Association 86, $227-238$.

Gray, J. M. \& Sutherland, D. G. 1977. The 'Oban-Ford' moraine: a reappraisal. In Gray, J. M. \& Lowe, J. J. (eds) Studies in the Scottish Lateglacial Environment, 33-44. Oxford: Pergamon.

Gugliemi Y. \& Cappa, F. 2010. Regional-scale relief evolution and large landslides: insights from geomechanical analyses in the Tinée Valley (southern French Alps). Geomorphology 117, 121-129.

Hall, A. M. 1991. Pre-Quaternary landscape evolution in the Scottish Highlands. Transactions of the Royal Society of Edinburgh: Earth Sciences 82, 1-26.

Hall, A. M., Binnie, S. A., Sugden, D. E., Dunai, T. J. \& Wood, C. 2016. Late readvance and rapid final deglaciation of the last ice sheet in the Grampian Mountains, Scotland. Journal of Quaternary Science 31, 869-878.

Hallet, B. 2013. Stone circles: form and soil kinematics. Philosophical Transactions of the Royal Society A371, 20120357.

Harbor, J. \& Warburton J. 1993. Relative rates of glacial and nonglacial erosion in alpine environments. Arctic and Alpine Research 25, 1-7.

Harkness, D. D. \& Wilson, H. W. 1979. Scottish Universities Research and Reactor Centre radiocarbon measurements III. Radiocarbon 21, 203-256.

Harris, C. 2013. Slope deposits and forms. In Elias, S. A. \& Mock, C. J. (eds) Encyclopedia of Quaternary Science, Second Edition, Volume 3, 481-489. Amsterdam: Elsevier.

Harris, C., Kern-Luetschg, M., Murton, J. B., Font, M., Davies, M. \& Smith, F. 2008. Solifluction processes on permafrost and non-permafrost slopes: results of a large-scale laboratory simulation. Permafrost and Periglacial Processes 19, 359-378.

Harrison, S. 1996. Paraglacial or periglacial? The sedimentology of slope deposits in upland Northumberland. In Anderson, M.G. \& Brooks, S.M. (eds) Advances in Hillslope Processes, 1197-1218. Chichester: Wiley.

Harrison, S. 2002. Lithological variability of Quaternary slope deposits in the Cheviot Hills, U.K. Proceedings of the Geologists' Association 113, 121-138.

Harrison, S., Whalley, W. B. \& Anderson, E. 2008. Relict rock glaciers and protalus lobes in the British Isles: implications for Late Pleistocene mountain geomorphology and palaeoclimate. Journal of Quaternary Science 23, 287-304.

Harrison, S., Bailey, R.M., Anderson, E., Arnold, L. \& Douglas, T. 2010. Optical dates from British Isles 'solifluction sheets' suggest rapid landscape response to Late Pleistocene climate change. Scottish Geographical Journal 126, 101-111.

Harrison S., Rowan, A.V., Glasser, N. F., Knight, J., Plummer, M. A. \& Mills, S. C. 2014. Little Ice Age glaciers in Britain: glacier-climate modelling in the Cairngorm Mountains. The Holocene 24, 135-140.

Harvey, A. M. 1986. Geomorphic effects of a 100 year storm in the Howgill Fells, Northwest England. Zeitschrift für Geomorphologie 30, 71-91. 
Hinchliffe, S. 1999. Timing and significance of talus slope reworking, Trotternish, Skye, northwest Scotland. The Holocene 9, 483-494.

Hinchliffe, S., Ballantyne, C. K. \& Walden, J. 1998. The structure and sedimentology of relict talus, Trotternish, northern Skye, Scotland. Earth Surface Processes and Landforms 23, 545560 .

Hinchliffe, S. \& Ballantyne, C. K. 1999. Talus accumulation and rockwall retreat, Trotternish, Isle of Skye, Scotland. Scottish Geographical Journal 115, 53-70.

Hinchliffe, S. \& Ballantyne, C.K. 2009. Talus structure and evolution on sandstone mountains in NW Scotland. The Holocene 19, 477-486.

Hippolyte, J-C., Bourlès, D., Léanni, L., Braucher, R., Chauvet, F. \& Lebatard, A. E. 2012. ${ }^{10}$ Be ages reveal $>12 \mathrm{ka}$ of gravitational movement in a major sackung of the western Alps (France). Geomorphology 171-172, 139-153.

Holmes, G. 1984. Rock slope failure in parts of the Scottish Highlands. Unpublished PhD thesis, University of Edinburgh.

Hopkinson, C. \& Ballantyne, C. K. 2014. Age and origin of blockfields on Scottish mountains. Scottish Geographical Journal 130, 116-141.

Hovius, N. \& Meunier, P. (2012) Earthquake-induced landsliding and patterns of seismicallyinduced landsliding. In Clague, J. J. \& Stead, D. (eds) Landslides: Types, Mechanisms and Modeling, 24-36. Cambridge: Cambridge University Press.

Hubbard, A., Bradwell, T., Golledge, N., Hall, A. M., Patton, H., Sugden, D. E., Cooper, R. \& Stoker, M. 2009. Dynamic cycles, ice streams and their impact on the extent, chronology and deglaciation of the British-Irish ice sheet. Quaternary Science Reviews 28, 758-776.

Huijzer, B. \& Vandenberghe, J. 1998. Climatic reconstruction of the Weichselian Pleniglacial in northwestern and central Europe. Journal of Quaternary Science 13, 391-417.

Huisink, M. 2000. Changing river styles in response to Weichselian climate changes in the Vecht valley, eastern Netherlands. Sedimentary Geology 133, 115-134.

Hutchinson, J. N. 2010. Relict sand wedges in soliflucted London Clay at Wimbledon, London, UK. Proceedings of the Geologists' Association 121, 444-454.

Innes, J. L. 1983. Lichenometric dating of debris-flow deposits in the Scottish Highlands. Earth Surface Processes and Landforms 8, 579-588.

Innes, J. L. 1986. Textural properties of regoliths on vegetated steep slopes in upland regions, Transactions of the Royal Society of Edinburgh: Earth Sciences 77, 241-250.

Isarin, R. F. B. 1997. Permafrost distribution and temperatures in Europe during the Younger Dryas. Permafrost and Periglacial Processes 8, 313-333.

Jansen, J. D., Codilean, A. T., Bishop, P. \& Hoey T. B. 2010. Scale dependence of lithological control on topography: bedrock channel geometry and catchment morphology in Western Scotland. Journal of Geology 118, 223-246.

Jansen, J. D., Fabel, D., Bishop, P., Xu, S., Schnabel, C. \& Codilean, A. T. 2011. Does decreasing paraglacial sediment supply slow knickpoint retreat? Geology 39, 543-546.

Jarman, D. 2006. Large rock-slope failures in the Highlands of Scotland: characterisation, causes and spatial distribution. Engineering Geology 83, 161-182. 
Jarman, D. 2007. Introduction to the mass movements in the older mountain areas of Great Britain. In Cooper, R. G. (ed.) Mass Movements in Great Britain. Geological Conservation Review Series 33, 33-56. Peterborough: Joint Nature Conservation Committee.

Jarman, D., Wilson, P. \& Harrison, S. 2013. Are there any relict rock glaciers in the British mountains? Journal of Quaternary Science 28, 131-143.

Jarman, D. \& Ballantyne, C. K. 2002. Beinn Fhada, Kintail: a classic example of paraglacial rock-slope deformation. Scottish Geographical Journal 118, 59-68.

Jenkins, A., Ashworth, P. J., Ferguson, R. I., Grieve, I. C., Rowling, P. \& Stott, T. A. 1988. Slope failures in the Ochil Hills, Scotland, November 1984. Earth Surface Processes and Landforms 13, 69-76.

Kääb, A. \& Kneisel, C. 2006. Permafrost creep within a recently deglaciated glacier foreland: Muragl, Swiss Alps. Permafrost and Periglacial Processes 17, 79-85.

Kasse, C., Vandenberghe, D., De Corte, F. \& Van Den Haute, P. 2007. Late Weichselian fluvioaeolian sands and coversands of the type locality Grubbenvorst (southern Netherlands): sedimentary environments, climate record and age. Journal of Quaternary Science 22, 695708.

Kelletat, D. 1970. Rezente Periglazialerscheinungen im Schottischen Hochland. Göttinger Geographische Abhandlungen 51, 67-140.

Kinnard, C. \& Lewkowicz, A.G. 2006. Frontal advance of turf-banked solifluction lobes, Kluane Range, Yukon Territory, Canada. Geomorphology 73, 261-276.

Kirkbride, M. P., Everest, J., Benn, D. I., Gheorghiu, D. \& Dawson, A. G. 2014. Late-Holocene and Younger Dryas glaciers in the northern Cairngorm Mountains, Scotland. The Holocene 24, $141-148$.

Kotarba, A. 1984. Slope features in areas of high relief in maritime climate (with the Island of Rhum as example). Studia Geomorphologica Carpatho-Balcanica 17, 77-88.

Lamb, H. H. 1991. Historic Storms of the North Sea, British Isles and Northwest Europe. Cambridge: Cambridge University Press.

Langdon, D. G. \& Barber, K. E. 2005. The climate of Scotland over the last 5000 years inferred from multiproxy peatland records: inter-site correlations and regional variability. Journal of Quaternary Science 20, 549-566.

Lauder, T. D. 1830. An Account of the Great Floods of August, 1829 in the Province of Moray and Adjoining Districts. Edinburgh: Adam Black.

Lewkowicz, A. G. 2007. Dynamics of active-layer detachment failures, Fosheim Peninsula, Ellesmere Island, Nunavut, Canada. Permafrost and Periglacial Processes 18, 89-103.

Lewkowicz, A. G. \& Harris, C. 2005. Morphology and geotechnique of active-layer detachment failures in discontinuous and continuous permafrost, northern Canada. Geomorphology 69, $275-297$.

Lewin, J., Macklin, M. G. \& Johnstone, E. 2005. Interpreting alluvial archives: sedimentological factors in the British Holocene alluvial record, Quaternary Science Reviews 24, 1873-1889.

Lewin, J. \& Macklin, M. G. 2003. Preservation potential for Late Quaternary river alluvium. Journal of Quaternary Science 18, 107-120. 
Lewin, J. \& Weir, M. J. C. 1977. Morphology and recent history of the lower Spey. Scottish Geographical Magazine 93, 45-51.

Lowe, J. J., Palmer, A. P., Carter-Champion, A., Macleod, A., Ramirez-Rojas, I. \& Timms, R. G. O. 2017. Stratigraphy of a Lateglacial lake basin sediment sequence at Turret Bank, upper Glen Roy, Lochaber: implications for the age of the Turret Fan. Proceedings of the Geologists' Association 128, 110-124.

Luckman, B. H. 1992. Debris flows and snow avalanche landforms in the Lairig Ghru, Cairngorm Mountains, Scotland. Geografiska Annaler 74A, 109-121.

Macklin, M. G., Jones, A. F. \& Lewin, J. 2010. River response to rapid Holocene environmental change: evidence and explanation in British catchments. Quaternary Science Reviews 29, $1555-1576$.

Macklin, M. G., Lewin, J. \& Jones, A. F. 2013. River entrenchment and terrace formation in the UK Holocene. Quaternary Science Reviews 76, 194-206.

MacLeod, A., Palmer, A. P., Lowe, J. J., Rose, J., Bryant, C. \& Merritt, J. 2011. Timing of glacier response to Younger Dryas climatic cooling in Scotland. Global and Planetary Change 79, 264-274.

Maizels, J. K. 1983a. Channel changes, palaeohydrology and deglaciation: evidence from some Lateglacial sandur deposits of northeast Scotland. Quaternary Studies in Poland 4, 171-187.

Maizels, J. K. 1983b. Proglacial channel systems: change and thresholds for change over long, intermediate and short time-scales. Special Publications of the International Association of Sedimentologists 6, 251-266.

Maizels, J. K. \& Aitken, J. 1991. Palaeohydrological change during deglaciation in upland Britain: a case study from northeast Scotland. In Starkel, L., Gregory, K. J. \& Thornes, J. B. (eds) Temperate Palaeohydrology: Fluvial Processes in the Temperate Zone during the last 15,000 years, 105-145. Chichester: Wiley.

Marren, P. M. 2001. Sedimentology of proglacial rivers in eastern Scotland during the Late Devensian. Transactions of the Royal Society of Edinburgh: Earth Sciences 92, 149-171.

Matsuoka, N. 2001. Solifluction rates, processes and landforms: a global review. Earth-Science Reviews 55, 107-134.

Matthews, J. A. \& Briffa, K. R. 2005. The 'Little Ice Age': re-evaluation of an evolving concept. Geografiska Annaler 87A, 17-36.

McColl, S. T. 2012. Paraglacial rock-slope stability. Geomorphology 153-154, 1-16.

McEwen, L. J. 1989. River channel changes in response to flooding in the upper River Dee catchment, Aberdeenshire, over the last 200 years. In Beven, K. \& Carling, P. (eds) Floods: Hydrological, Sedimentological and Geomorphological Implications, 219-238. Chichester: Wiley.

McEwen, L. J. 1994. Channel pattern adjustment and streampower variations on the middle River Coe, Western Grampian Highlands. Catena 21, 357-374.

McEwen L. J. 1997. Geomorphological change and fluvial landscape evolution in Scotland during the Holocene. In Gordon, J. E. (ed.) Reflections on the Ice Age in Scotland, 116-129. Glasgow: Scottish Association of Geography Teachers and Scottish Natural Heritage. 
McEwen, L. J. \& Werritty A. 1988. The hydrology and long-term geomorphic significance of a flash flood in the Cairngorm Mountains, Scotland. Catena 21, 357-374.

McEwen, L. J. \& Werritty A. 2007. 'The Muckle Spate of 1829' : the physical and societal impact of a catastrophic flood on the River Findhorn, Scottish Highlands. Transactions of the Institute of British Geographers 32, 66-89.

Mercier, D. 2011. La Géomorphologie Paraglaciaire. Saarbrücken: Éditions Universitaires Européennes, $256 \mathrm{pp}$.

Merritt, J. W., Auton, C. A., Connell, E. R., Hall, A. M. \& Peacock, J. D. 2003. Cainozoic Geology and Landscape Evolution of North-East Scotland. Edinburgh: Memoir of the British Geological Survey.

Meunier, P., Hovius, N. \& Haines, A. J. 2008. Topographic site effects and the location of earthquake-induced landslides. Earth and Planetary Science Letters 275, 221-232.

Milne, F. D., Werritty, A., Davies, M.C.R. \& Brown, M.J. 2009. A recent debris flow event and implications for hazard management. Quarterly Journal of Engineering Geology and Hydrogeology 42, 51-60.

Milne, F. D., Brown, M. J. \& Werritty, A. 2010. A hazardous channelized debris flow in Glen Ogle, Stirlingshire. Scottish Journal of Geology 46, 181-189.

Milne, F. D., Brown, M. J., Davies, M. C. R. \& Cameron, G. 2015. Some key topographic and material controls on debris flows in Scotland. Quarterly Journal of Engineering Geology and Hydrogeology 48, 218-223.

Mitchell, W. A. 2008. Quaternary geology of part of the Kale Water catchment, western Cheviot Hills, Scotland. Scottish Journal of Geology 44, 51-63.

Moore, R., Carey, J., Mills, A., Martin, S., Irinder, S., Kerry, L., Leask, G. \& Simmons, A. 2006. Recent landslide impacts on the UK Scottish road network: investigation into the mechanisms, causes and management of landslide risk. In Ashaari, M. (ed.) Proceedings of the International Conference on Slopes, Malaysia, 2006, 223-237. Kuala Lumpur, Public Works Department.

Morrocco, S. M., Ballantyne, C. K. Spencer, J. Q. \& Robinson, R. A. J. 2007. Age and significance of aeolian sediment reworking on high plateaux in the Scottish Highlands. The Holocene 17, 349-360.

Mottershead, D. 1978. High altitude solifluction and postglacial vegetation, Arkle, Sutherland. Transactions of the Botanical Society of Edinburgh 43, 17-24.

Murton, J. B. 2013. Ice wedges and ice-wedge casts. In Elias, S.A. \& Mock, C.J. (eds) Encyclopedia of Quaternary Science, Second Edition, Volume 3, 436-451. Amsterdam, Elsevier.

Murton, J. B. \& Ballantyne, C. K. 2017. Periglacial and permafrost ground models for Great Britain. Geological Society, London, Engineering Group Special Publications 28, 501-597.

Murton, J. B. \& French, H. M. 1993a. Thaw modification of frost-fissure wedges, Richards Island, Pleistocene Mackenzie Delta, western Arctic Canada. Journal of Quaternary Science 8, $185-196$. 
Murton, J. B. \& French, H. M. 1993b. Thermokarst involutions, Summer Island, Pleistocene Mackenzie Delta, western Canadian Arctic. Permafrost and Periglacial Processes 4, $217-$ 229.

Murton, J. B \& Kolstrup, E. 2003. Ice-wedge casts as indicators of palaeotemperatures: precise proxy or wishful thinking? Progress in Physical Geography 27, 155-170.

Nichol, D. 2009. A peat slide at Glenfiddich, East Grampian Highlands. Scottish Journal of Geology 45, 183-186.

Nielsen, P. R., Dahl, S. O., Jansen, H. L. \& Støren, E. N. 2016. Holocene aeolian sedimentation and episodic mass-wasting events recorded in lacustrine sediments on Langøya in Vesterålen, northern Norway. Quaternary Science Reviews 148, 146-162.

Palmer, A. P. \& Lowe, J. J. 2017. Dynamic landscape changes in Glen Roy and vicinity, west Highland Scotland, during the Younger Dryas and early Holocene: a synthesis. Proceedings of the Geologists' Association 128, 2-25.

Peacock, J. D. 1986. Alluvial fans and an outwash fan in upper Glen Roy, Lochaber. Scottish Journal of Geology 22, 347-366.

Peacock, J. D. \& May, F. 1993. Pre-Flandrian slope deformation in the Scottish Highlands: examples from Glen Roy and Glen Gloy. Scottish Journal of Geology 29, 183-189.

Pennington, W., Haworth, E. Y., Bonny, A.P. \& Lishman, J. P. 1972. Lake sediments in northern Scotland. Philosophical Transactions of the Royal Society B264, 191-294.

Phillips, W. M., Hall, A. M., Mottram, R., Fifield, L. K. \& Sugden, D. E. 2006. Cosmogenic ${ }^{10}$ Be and ${ }^{26} \mathrm{Al}$ exposure ages of tors and erratics, Cairngorm Mountains, Scotland: timescales for the development of a classic landscape of selective linear erosion. Geomorphology 73, 222-245.

Plug, L. J. \& Werner, B. T. 2008. Modelling of ice-wedge networks. Permafrost and Periglacial Processes 19, 63-69.

Reid, E., Thomas, M. F. \& Tipping, R. M. 2003. Holocene alluvial fan and fluvial activity in upper Glen Licht, Kintail. In Tipping, R. M. (ed.) The Quaternary of Glen Affric and Kintail: Field Guide, 157-164. London: Quaternary Research Association.

Reid, E. \& Thomas, M. F. 2006. A chronostratigraphy of mid- and late-Holocene slope evolution: Creagan a'Chaorainn, Northern Highlands, Scotland. The Holocene 16, 429-444.

Reimer, P. J., Bard, E., Bayliss, A. et al. 2013. IntCal13 and Marine13 Radiocarbon Age Calibration Curves 0-50,000 Years cal BP. Radiocarbon 55, 1869-1887.

Rhind, D. W. 1969. The Terraces of the Tweed Valley. Unpublished PhD Thesis, University of Edinburgh.

Riddell, K. J. \& Fuller, T. W. 1995. The Spey Bay geomorphological study. Earth Surface Processes and Landforms 20, 671-686.

Ringrose, P. S. 1989a. Palaeoseismic (?) liquifaction event in late Quaternary lake sediments at Glen Roy, Scotland. Terra Nova 1, 57-62.

Ringrose, P. S. 1989b. Recent fault movement and palaeoseismicity in western Scotland. Tectonophysics 163, 305-314.

Robertson-Rintoul, M. 1986. A quantitative soil-stratigraphic approach to the correlation and 
dating of post-glacial river terraces in Glen Feshie, Western Cairngorms. Earth Surface Processes and Landforms 11, 606-617.

Rose, J. 1975. Raised beach gravels and ice-wedge casts at Old Kilpatrick, near Glasgow. Scottish Journal of Geology 11, 15-21.

Rumsby, B., McVey, R. \& Brasington, J. 2001. The potential for high resolution fluvial archives in braided rivers: quantifying historic reach-scale channel and floodplain development in the River Feshie, Scotland. In Maddy, D., Macklin, M. G. \& Woodward, J. (eds) Basin Sediment Systems: Archives of Environmental Change, 445-467. Rotterdam: Balkema.

Rumsby, B. T., Brasington, J., Langham, J. A., McLelland, S. J., Middleton, R. \& Rollinson, G. 2008. Monitoring and modelling particle and reach-scale morphological change in gravel-bed rivers: applications and challenges. Geomorphology 93, 40-54.

Russell, A. J. 1995. Late Devensian meltwater movement and storage within the Ochil Hills, Scotland. Scottish Journal of Geology 31, 65-78.

Russell, A. J., Tweed, F. S. \& Harris, T. 2003. High-energy sedimentation, Creag Aoil, Spean Bridge, Scotland: implications for meltwater movement and storage during Loch Lomond Stadial (Younger Dryas) ice retreat. Journal of Quaternary Science 18, 415-430.

Russell, A. J. \& Marren, P. W. 1998. A Younger Dryas (Loch Lomond Stadial) jökulhlaup deposit, Fort Augustus, Scotland. Boreas 27, 231-242.

Rydval, M., Loader, N. J., Gunnarson, B. E., Druckenbrod, D. L., Linderholm, H. W., Moreton, S. G. Wood, C. V. \& Wilson, R. 2017. Reconstructing 800 years of summer temperatures in Scotland from tree rings. Climate Dynamics DOI: 10.1007/s00382-016-3478-8.

Salt, K. E. \& Ballantyne, C. K. 1997. The structure and sedimentology of relict talus, Knockan, Assynt, NW Scotland. Scottish Geographical Magazine 113, 82-89.

Sanchez, G., Rolland, Y., Corsini, M., Broucher, R., Bourlès, D., Arnold, M. \& Aumaître, G. 2010. Relationships between tectonics, slope instability and climate change: cosmic ray exposure dating of active faults, landslides and glacial surfaces in the French Alps. Geomorphology 117, 1-13.

Sissons, J. B. 1977. Former ice-dammed lakes in Glen Moriston, Inverness-shire, and their significance in upland Britain. Transactions of the Institute of British Geographers 2, 224242.

Sissons, J. B. 1979a. The later lakes and associated fluvial terraces of Glen Roy, Glen Spean and vicinity. Transactions of the Institute of British Geographers 4, 12-29.

Sissons, J. B. 1979b. Catastrophic lake drainage in Glen Spean and the Great Glen, Scotland. Journal of the Geological Society, London 136, 215-224.

Sissons, J. B. 1982. A former ice-dammed lake and associated glacier limits in the Achnasheen area, central Ross-shire. Transactions of the Institute of British Geographers 7, 98-116.

Sissons, J. B. \& Cornish, R. 1983. Fluvial landforms associated with ice-dammed lake drainage in upper Glen Roy, Scotland. Proceedings of the Geologists' Association 94, 45-52.

Sletten, K., Blikra, L. H., Ballantyne, C. K., Nesje, A. \& Dahl, S. O. 2003. Holocene debris flows recognised in a lacustrine sedimentary succession: sedimentology, chronostratigraphy and cause of triggering. The Holocene 13, 907-920. 
Small, D. \& Fabel, D. 2016. Was Scotland deglaciated during the Younger Dryas? Quaternary Science Reviews 145, 259-263.

Smith, D. E., Stewart, I. S., Harrison, S. \& Firth, C. R. 2009. Late Quaternary neotectonics and mass movement in South East Raasay, Inner Hebrides, Scotland. Proceedings of the Geologists' Association 120, 145-154.

Smith, D. E., Barlow, N. L. M., Bradley, S., Firth, C. R., Hall, A. M., Jordan, J. T. \& Long, D. 2018. Quaternary sea level change in Scotland. Earth and Environmental Science Transactions of the Royal Society of Edinburgh (This issue).

Spink, T. W. 1991. Periglacial discontinuities in Eocene Clay near Denham, Buckinghamshire. Geological Society, London, Engineering Geology Special Publications 7, 389-396.

Stewart, I. S., Firth, C. R., Rust, D. J., Collins, P. E. F. \& Firth, J.A. 2001. Postglacial fault movement and palaeoseismicity in western Scotland: a reappraisal of the Kinloch Hourn fault, Kintail. Journal of Seismology 6, 307-328.

Strachan, G. J. 2015. Debris flow activity and gully propagation: Glen Docherty, Wester Ross. Scottish Journal of Geology 51, 69-80.

Strachan, G. J. 2017. A peaty-debris flow in Glen Docherty, Wester Ross. Scottish Geographical Magazine 133, 54-68.

Stuiver, M., Reimer, P. J. \& Reimer, R.W. 2016. CALIB 7.1. http://calib.org (accessed June 2017).

Sugden, D. E. 1971. The significance of periglacial activity on some Scottish mountains. Geographical Journal 137, 388-392.

Thom, A. S. \& Ledger, D. C. 1976. Rainfall, runoff and climatic change. Proceedings of the Institution of Civil Engineers 61, 633-652.

Tipping, R. 1992. The determination of the cause in the generation of major prehistoric valley fills in the Cheviot Hills, Anglo-Scottish border. In Needham, S. \& Macklin, M. G. (eds) Alluvial Archaeology in Britain, 111-121. Oxford: Oxbow Monograph 27.

Tipping, R. 1994. Fluvial chronology and valley floor evolution of the upper Bowmont Valley, Borders Region, Scotland. Earth Surface Processes and Landforms 19, 641-657.

Tipping, R. 1995a. Holocene landscape change at Carn Dubh, near Pitlochry, Perthshire, Scotland. Journal of Quaternary Science 10, 59-75.

Tipping, R. 1995b. Holocene evolution of a lowland Scottish landscape: Kirkpatrick Fleming. Part III, fluvial history. The Holocene 5, 184-195.

Tipping, R. 1998. The chronology of Late Quaternary fluvial activity in part of the Milfield Basin, northeast England. Earth Surface Processes and Landforms 23, 845-856.

Tipping, R. 1999. Moffat Basin: Holocene fluvial stratigraphy and chronology. In Tipping, R. (ed.) The Quaternary of Dumfries and Galloway: Field Guide, 153-159. London: Quaternary Research Association.

Tipping, R. 2007. Multidisciplinary approaches to defining historic period coastal and fluvial changes at Dunglass Burn, south east Scotland. Scottish Geographical Journal 123, 16-32.

Tipping, R., Carter, S. \& Haggart, B. A. 1994. Late Quaternary valley floor evolution in the vicinity of Carradale. Kintyre. Scottish Journal of Geology 30, 131-145. 
Tipping, R., Milburn, P. \& Halliday, S. 1999. Fluvial processes and land-use change 2000 years ago in upper Annandale, southern Scotland. In Brown, A. G. \& Quine, T. A. (eds) Fluvial Processes and Environmental Change, 311-327. Chichester: Wiley.

Tipping, R., Jones, A. P., Carter, S., Holden, T. \& Cressey, M. 2008. The chronology and longterm dynamics of a low energy river system: the Kelvin Valley, central Scotland. Earth Surface Processes and Landforms 33, 910-910.

Tipping, R. \& Halliday, S. P. 1994. The age of alluvial fan deposition at a site in the Southern Uplands of Scotland. Earth Surface Processes and Landforms 19, 333-348.

Van Vliet, B. \& Langohr, R. 1981. Correlations between fragipans and permafrost with special reference to silty Weichselian deposits in Belgium and northern France. Catena 8, 137-154.

Veyret, Y. \& Coque-Delhuille, B. 1993. Réflexions prélimininaires sur les phénomènes catastrophiques affectant la tourbière-couverture aux îles Shetland. Norois 40, 653-664.

Vandenberghe, J. 2003. Climate forcing of fluvial system development: an evolution of ideas. Quaternary Science Reviews 22, 2053-2060.

Vandenberghe, J. 2008. The fluvial cycle at warm-cold-warm transitions in lowland regions: a refinement of theory. Geomorphology 98, 275-284.

Vandenberghe, J. 2013. Cryoturbation structures. In Elias, S. A. \& Mock, C. J. (eds) Encyclopedia of Quaternary Science, Second Edition, Volume 3, 430-435. Amsterdam: Elsevier.

Wanner, H., Solomina, O., Grosjean, M., Ritz, S.P. \& Jetel, M. 2011. Structure and origin of Holocene cold events. Quaternary Science Reviews 30, 3109-3123.

Ward, R. G. W. 1985. Geomorphological evidence of avalanche activity in Scotland, Geografiska Annaler 67A, 247-256.

Ward, R. G. W., Langmuir, E. D. G. \& Beatty, B. 1985. Snow profiles and avalanche activity in the Cairngorm Mountains, Scotland. Journal of Glaciology 31, 18-27.

Watters, R. J. 1972. Slope stability in the metamorphic rocks of the Scottish Highlands. Unpublished PhD thesis, University of London.

Wells, S. G. \& Harvey, A. M. 1987. Sedimentologic and geomorphic variations in stormgenerated alluvial fans, Howgill Fells, northwest England. Geological Society of America Bulletin 98, 182-194.

Werritty, A. 1984. Stream response to flash floods in Scotland. In Burt, T. P. \& Walling, D. E. (eds) Catchment experiments in Fluvial Geomorphology, 537-560. Norwich: Geobooks.

Werritty, A. \& Ferguson, R. I. 1980. Pattern changes on a Scottish braided river over 1, 30 and 200 years. In Cullingford, R. A., Davidson, D. A. \& Lewin, J. (eds) Timescales in Geomorphology, 53-68. Chichester: Wiley.

Werritty, A. \& Hoey, T. 2003. Geomorphological changes and trends in Scotland: river channels and processes. Scottish Natural Heritage Commissioned Report F00AC107B, 90 pp.

Werritty, A. \& Leys, K. 2001. The sensitivity of Scottish rivers and upland valley floors to recent environmental change. Catena 49, 251-273.

Werritty A. \& McEwen, L. J. 1997. The fluvial geomorphology of Scotland. In Gregory, K. J. (ed) Fluvial Geomorphology of Great Britain, 21-32. Geological Conservation Review Series, 
13. London: Chapman \& Hall.

Whitbread, K., Jansen, J., Bishop, P. \& Attal, M. 2015. Substrate, sediment and slope controls on bedrock channel geometry in postglacial streams. Journal of Geophysical Research: Earth Surface 120, 779-798.

Whittington, G. 1985. The Little Ice Age and Scotland's weather. Scottish Geographical Magazine 101, 174-178.

Wilson, P. 1993. Ploughing-boulder characteristics and associated soil properties in the Lake District and southern Scotland. Scottish Geographical Magazine 109, 18-26.

Winter, M. G., Heald, A. P., Parsons, J. A., Macgregor, F. \& Shackman, L. 2006. Scottish debrisflow events of August 2004. Quarterly Journal of Engineering Geology and Hydrogeology 39, 73-78.

Winterbottom, S. J. 2000. Medium and short-term channel planform changes on the Rivers Tay and Tummel, Scotland. Geomorphology 34, 195-208.

Worsley, P. 2014. Ice-wedge growth and casting in a Late Pleistocene periglacial, fluvial succession at Baston, Lincolnshire. Mercian Geologist 18, 159-170.

Young, J. A. T. 1976. The terraces of Glen Feshie, Inverness-shire. Transactions of the Royal Society of Edinburgh 69, 501-512.

Young, J. A. T. 1978. The landforms of upper Strathspey. Scottish Geographical Magazine 94, 76-94.

Zerathe, S., Lebourg, T., Braucher, R. \& Bourlès, D. 2014. Mid-Holocene cluster of large-scale landslides revealed in the Southwestern Alps by ${ }^{36} \mathrm{Cl}$ dating. Insight on an Alpine-scale landslide activity. Quaternary Science Reviews 90, 106-127.

\section{Captions to Figures}

Figure 1 Location of key sites mentioned in the text.

Figure 2 Environmental change over the past 18,000 years. (a) Greenland NGRIP ice core $\delta^{18} \mathrm{O}$ record, which indicates periods of relative cooling and warming. (b) Lateglacial July air temperatures inferred from chironomid assemblages recovered from Whitrig Bog in SE Scotland, showing rapid summer warming at $\sim 14.7 \mathrm{ka}$ and $\sim 11.7 \mathrm{ka}$ (Brooks \& Birks 2000). (c) Schematic representation of glacier ice cover, 18-11 ka. (d) Periods when equilibrium permafrost probably extended to sea level in Scotland. (e) Major chronological subdivisions of the postglacial period in Scotland. YDS: Younger Dryas Stade.

Figure 3 Maximum extent of glaciation during the Younger Dryas Stade, and documented distribution of landforms indicative of Lateglacial permafrost (ice-wedge pseudomorphs, involutions and polygonal crop marks representing former contraction crack polygons).

Figure 4 Simplified terrestrial paraglacial sediment cascade. Most primary sediment stores have experienced a transition from net accumulation to net erosion during the postglacial period. Adapted from Ballantyne, C. K. (2002a) Quaternary Science Reviews 21, 1935-2017 with permission from Elsevier. 
Figure 5 (a) Schematic illustration of periglacial and paraglacial landforms that developed on Scottish mountains during the Lateglacial period. (b) Schematic illustration of the range of Holocene (active) periglacial landforms on Scottish mountains. Because some landforms are restricted by regolith characteristics and hence by underlying lithology, the full range of Lateglacial or Holocene features is unlikely to be present on any single massif.

Figure 6 (a) Summit blockfield, Stob Bàn, NW Highlands. The large boulder is a quartzite erratic. (b) Tors at the summit of Beinn Mheadhoin, Cairngorms. The tor in the foreground is over $10 \mathrm{~m}$ high. (c) Large relict sorted circles, Glas Maol, SE Grampians. (d) Relict nonsorted relief stripes, Seana Braigh, NW Highlands. (e) Boulder lobes, Cairngorms. (f) Relict vegetated talus accumulations incised by debris flows, Trotternish, northern Skye.

Figure 7 Distribution of documented postglacial rock-slope failures $>0.25 \mathrm{~km}^{2}$ in the Scottish Highlands, almost all of which occurred on schists. Large postglacial RSFs in the Southern Uplands and Hebrides are not included, nor are debris-free scarps from which runout debris was removed by glacier ice during the YDS. Adapted from Jarman, D. (2006) Engineering Geology 83, 161-182, with permission from Elsevier.

Figure 8 Examples of postglacial rock-slope failures in Scotland. (a) Recent rockslide and runout debris, Am Bodach, Mamore Mountains [NN 179649]. (b) Arrested rockslide, Tom na Caillich, Northern Highlands [NH 440656]. (c) Complex rockslide, Loch Ericht [NN 530687]. (d) Arrested rockslide, Geal Charn, central Grampians [NN 468738]. (e) Hoglayers RSF and runout lobes, West Lomond Hill, Fife [NO 194071]. (f) Large rock-slope deformation, Bell Crag, Tweedsmuir Hills, Southern Uplands [NT 181128].

Figure 9 Summed normal kernel density estimates generated by 31 RSF ages from Scotland (22) and NW Ireland (9), calculated as time elapsed since deglaciation. (a) All RSFs. (b) RSFs outside the YDS glacier limits. (c) RSFs inside the YDS glacier limits. Extension of curves to the left of $0 \mathrm{ka}$ is an artefact of curve generation. From Ballantyne et al. (2014a) Quaternary Science Reviews 86, 144-157. Reproduced with permission.

Figure 10 Summed normal kernel density estimates for 31 dated catastrophic RSFs in Scotland and NW Ireland plotted against rates of glacio-isostatic uplift for three coastal locations in Scotland. Crustal uplift data are from Firth \& Stewart (2000). From Ballantyne et al. (2014a) Quaternary Science Reviews 86, 144-157. Reproduced with permission.

Figure 11 Examples of debris-free scarps representing the sites of Lateglacial rockslides from which debris was removed by glacier ice during the Loch Lomond Readvance. (a) Coire Sgrìodain, western Grampians [NN 355745]. (b) Coire Sron an Nid, central Grampians [NN 522772]. (c) Coire Sgréamhach, Sgorr Donuill, Western Grampians. (d) Coire Mhic Eacharna, Ardgour [NM 929634].

Figure 12 Kettled kame terraces formed at the margin of a YDS glacier merging westward into a large kettled outwash terrace (Moss of Achnacree) graded to a Lateglacial sea level of 10-12 m above present at the mouth of Loch Etive. Adapted from Gray, J. M. (1975) Proceedings of the Geologists' Association 86, 227-238. 
Figure 13 Terraces in Glen Dee, Cairngorms. The higher terraces rise over $10 \mathrm{~m}$ above the present floodplain, and represent postglacial incision of outwash deposited during glacier retreat around $\sim 16.5-15.5 \mathrm{ka}$. The low terrace adjacent to the present floodplain is probably late Holocene in age.

Figure 14 Lateglacial alluvial fans in Glen Roy. (a) The Brunachan fan, showing later terraces inset into the original fan and the two highest lake shorelines (at $325 \mathrm{~m}$ and $350 \mathrm{~m} \mathrm{OD}$ ) in the background. (b) The Annat fan in upper Glen Roy, showing how terraces formed by incision of the River Roy have cut back into the distal part of the original fan.

Figure 15 (a) Summit outcrop of Torridon Sandstone rounded by granular disaggregation, Beinn Dearg, Torridon. (b) Active sorted stripes, Tinto Hill, Southern Uplands. (c) Active solifluction terraces, Tom a' Choinnich, Fannich Mountains, NW Highlands. (d) Displacement of segmented columns by solifluction over 35 years, Fannich Mountains, NW Highlands.

Figure 16 Holocene aeolian landforms on high ground. (a) Wind stripes on Beinn a'Bhach-Ard, NW Highlands. (b) Deflation surface and residual island of eroding windblown sand, Ward Hill, Orkney. (c) Pit excavated through aeolian deposits $2.9 \mathrm{~m}$ deep on the summit of The Storr, Trotternish, Skye. (d) Section through plateau-margin aeolian sands, An Teallach, showing unweathered upper sand unit overlying lower weathered sand unit; the boundary lies between the two circular holes, from which samples for OSL dating were extracted.

Figure 17 Debris flows on Beinn Eighe (Torridon). Successive flows have transported lightcoloured quartzite debris across the subjacent darker Torridon Sandstone.

Figure 18 Debris flows and debris cones on the flanks of glacial troughs: Gleann Einich, Cairngorms (left) and Glen Docherty near Kinlochewe (right). Adapted from a map in Curry (1999a) and reproduced with the author's permission.

Figure 19 Gully-wall sections through relict talus at the southern end of the Trotternish Escarpment, Isle of Skye, showing the location of dated samples and the intervening sediment units. Gradients have been reduced for clarity. Adapted from Hinchliffe (1999).

Figure 20 Model of postglacial talus evolution proposed by Hinchliffe \& Ballantyne (2009). (a) Paraglacial stress release and Lateglacial frost wedging cause frequent rockfalls and rapid talus accumulation. (b) After several millennia, progressive stabilization of the rockwall has diminished rockfall supply; soil and vegetation cover develop on the talus. (c) Localised failure and gully development at the talus crest, and redeposition of sediment by debris flows and slopewash on the upper slope. (d) Debris flows and runoff within gullies result in downslope gully extension and deposition of sediments as debris cones.

Figure 21 Calibrated radiocarbon ages relating to debris-flow units overlying or underlying organic layers at nine sites on Skye and in the Scottish Highlands, showing possible periods of enhanced activity. The horizontal bars represent the 95\% confidence limits for each calibrated age. Sources: Brazier et al. (1988); Brazier \& Ballantyne (1989); Curry (2000a, 2000b); Reid \& Thomas (2006); Hinchliffe \& Ballantyne (2009). 
Figure 22 (a) Cuspate scars representing former translational landslides in till deposits, Glen Artney, southern Grampians. (b) Gullies eroded in till bluffs, Carn Bhan, northern Highlands. Many such gullies were initiated as translational landslides then modified by stream erosion.

Figure 23 Schematic illustration of river terraces in the Kirtle Water catchment and associated radiocarbon ages of dated organic material. (a) Terraces KB I to KB VI of the Kirk Burn near its confluence with Kirtle Water. (b) Terraces PG I to PG V of the middle reach of Kirtle Water near Palmersgill Bridge. The figures represent calibrated $\pm 1 \sigma$ age ranges (cal ${ }^{14} \mathrm{C}$ a) of radiocarbon dates, referenced to AD 2000. Adapted from Tipping (1995b).

Figure 24 Exposure on a small Holocene alluvial fan, the Edendon Fan [NN 715776]. Three peat layers (dark layers on the photograph) extend across the entire width of the fan. Radiocarbon dating of samples from the top and base of each peat layer has demonstrated that each intervening sediment bed represents a single depositional event. The lowest peat layer has developed on a terraced floodplain that ceased to aggrade between $\sim 27$ and $\sim 24 \mathrm{cal}{ }^{14} \mathrm{C}$ ka.

Figure 25 Calibrated radiocarbon ages relating to individual sediment deposition episodes on Holocene alluvial fans. Horizontal bars represent the $\pm 2 \sigma$ range and vertical dashes represent the median age. Dates from Glen Etive (Brazier et al. 1988), Dunglass (Tipping 2007) and most for the Southern Uplands (Foster et al. 2008) represent the onset of fan accumulation. Those for Edendon (Ballantyne \& Whittington 1999) and Gleann Licht (Reid et al. 2003) represent the onset of accumulation (oldest age) and timing of later sedimentation events.

Figure 26 (a) Channel planform change of the River Tummel above its confluence with the Tay, characteristic of the behaviour of a wandering gravel-bed river. Adapted from Winterbottom (2000). (b) Channel change of the River Clyde at its confluence with the River Medwin, showing downstream migration of meanders; $400 \mathrm{~m}$ above the confluence, the neck of a meander was cut through between 1858 and 1909. Adapted from Brazier et al. (1993).

Figure 27 The River Coe above Loch Achtriochan, a typical wandering gravel-bed river, photographed in June 2005. The palaeochannel nearest the road was active before 1875. The main channel switched to the far side of the floodplain before 1887 and remained there until after 1962, before switching to its 2005 position sometime before 1988 (McEwen 1994). 
Table 1 Typology of Scottish fluvial environments

$\begin{array}{lll}\text { Category Characteristics } & \text { Examples }\end{array}$

1. Active braiding

2. Locally braided

3. Wandering gravel-bed

4. Wandering gravel bed with confined reaches

5. Active meandering

6. Inactive meandering

7. Confined meandering

8. Bedrock rivers

9. Mountain torrents

10. Headwater streams

11. Managed rivers
Rare. Major floods may cause avulsion and produce complex braiding that adjusts more slowly during moderate flood events.

Includes active confluence fans. Major floods may cause avulsion.

Common in upland valleys. Contain both braided and meandering reaches.

As (3), but with confined reaches that limit channel mobility.

Fairly rare, due to river management and possibly reduced sediment supply

Common on upland valley floors and in lowlands. Confinement by artificial means has reduced activity. Generally stable.

Confinement by terraces or bedrock limits channel change. Generally stable.

Bedrock-confined channels. Stable.

Stable, but vulnerable to change during extreme rainstorm events.

Generally stable if unaffected by land-use change.

Common on reaches of lowland and upland valley floors.
Lower Spey; N Esk

near Edzell; parts of

River Feshie

Feshie-Spey

confluence

Water of Tulla;

Dorback Burn

River Dee; part of

River Feshie

Derry Burn upstream

from Braemar

Strathglass; Allt

Dubhaig (Drumochter)

Parts of Rivers Dee and Findhorm

Linn of Dee

Allt Mór, Cairngorms

Ardessie Burn

Most major rivers

Classification based on Werritty \& Hoey (2003). Large catchments such as those of the Spey, Findhorn, Dee and Tweed include most of the above categories 


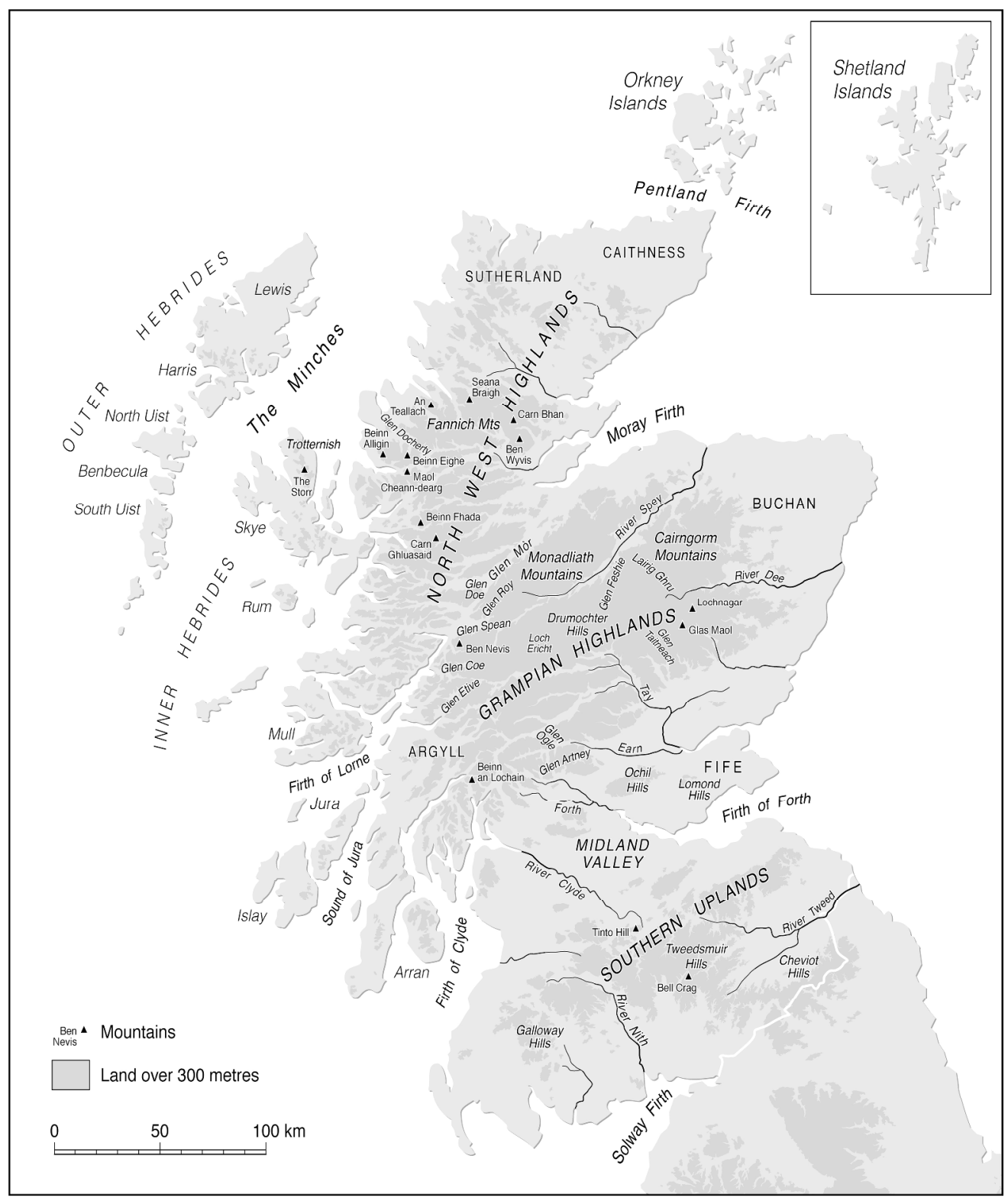

Figure 1 Location of key sites mentioned in the text.

$157 \times 187 \mathrm{~mm}(600 \times 600 \mathrm{DPI})$ 


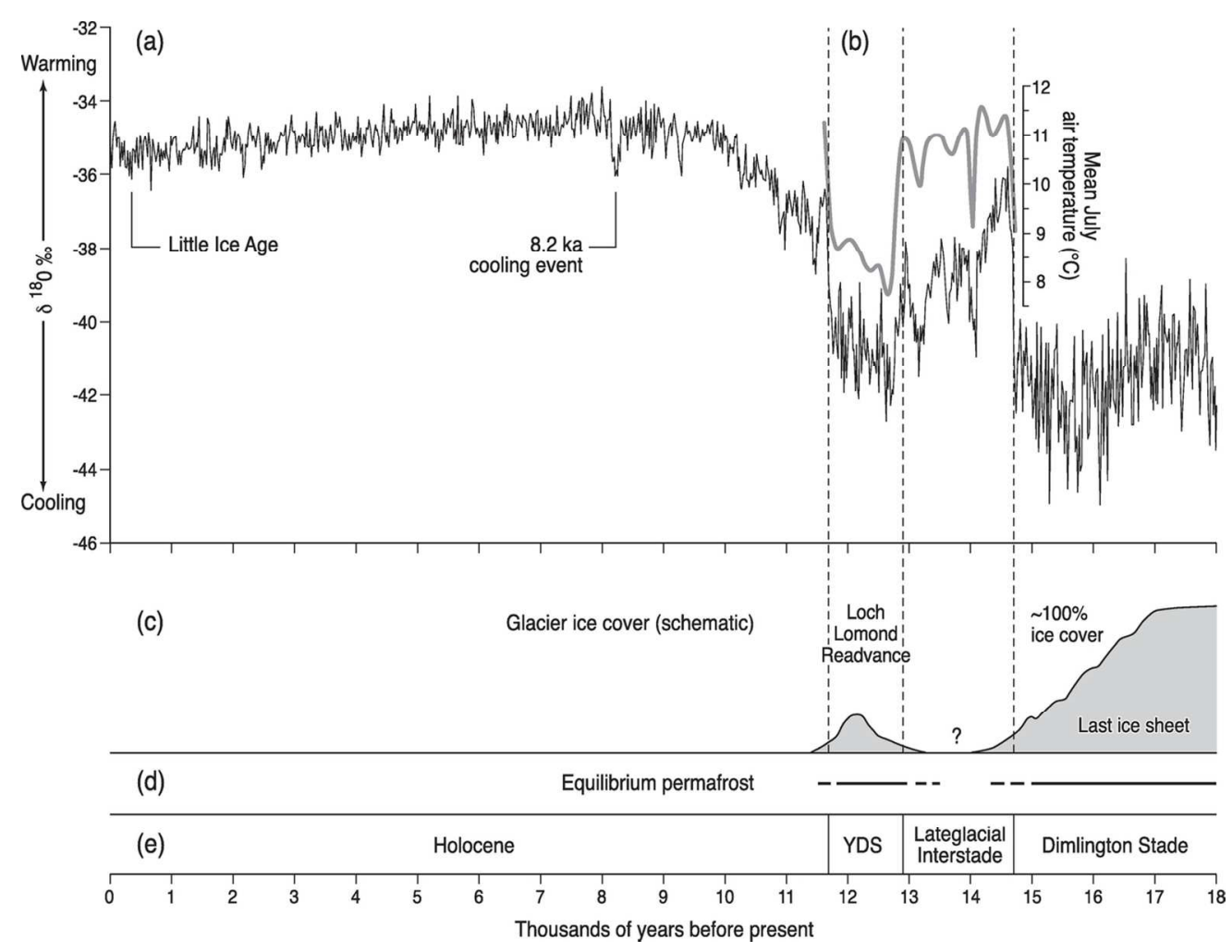

Figure 2 Environmental change over the past 18,000 years. (a) Greenland NGRIP ice core $\delta 180$ record, which indicates periods of relative cooling and warming. (b) Lateglacial July air temperatures inferred from chironomid assemblages recovered from Whitrig Bog in SE Scotland, showing rapid summer warming at $\sim 14.7 \mathrm{ka}$ and $\sim 11.7 \mathrm{ka}$ (Brooks \& Birks 2000). (c) Schematic representation of glacier ice cover, 18-11 ka. (d) Periods when equilibrium permafrost probably extended to sea level in Scotland. (e) Major chronological subdivisions of the postglacial period in Scotland. YDS: Younger Dryas Stade.

$121 \times 92 \mathrm{~mm}(300 \times 300 \mathrm{DPI})$ 


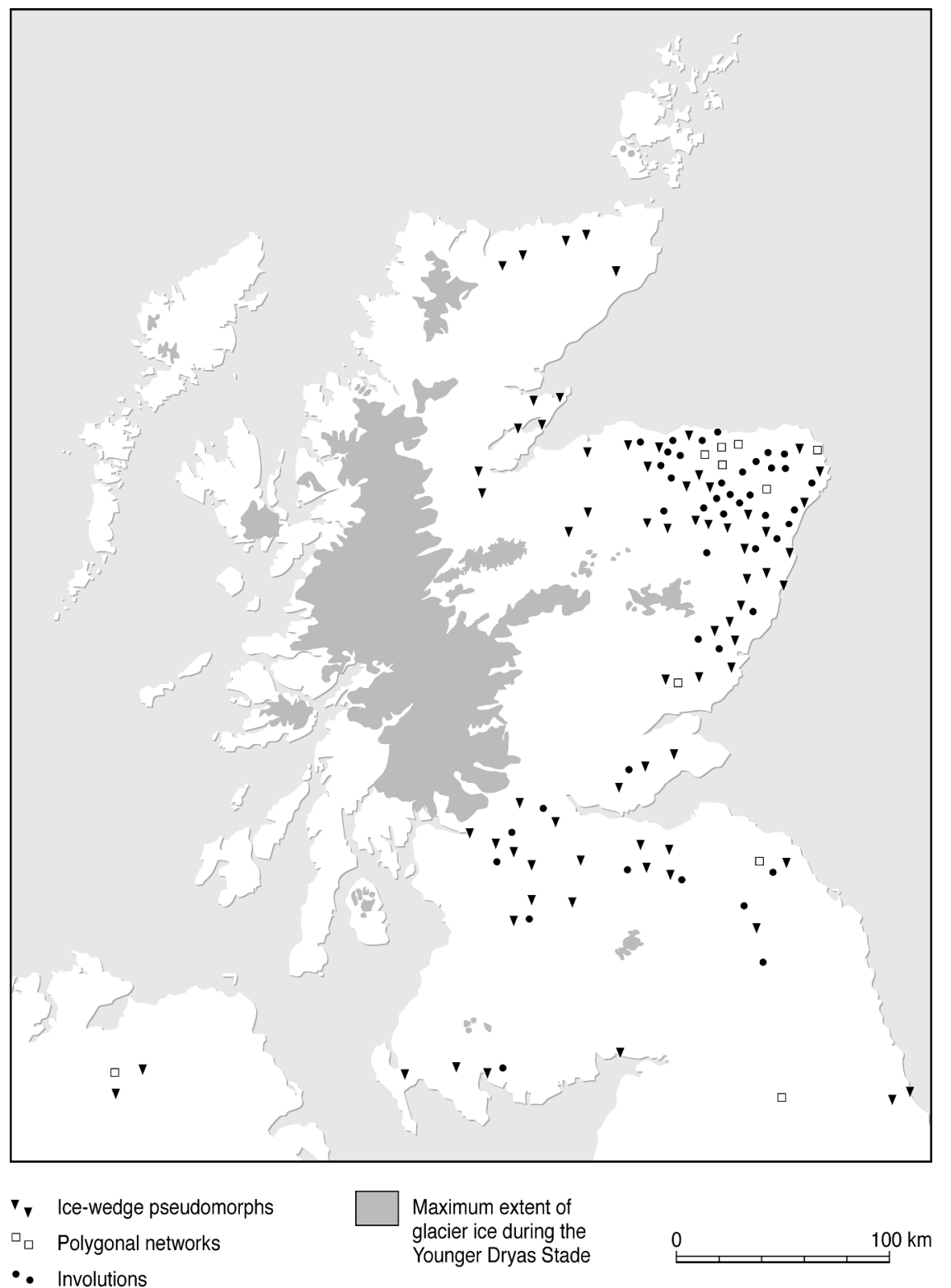

Figure 3 Maximum extent of glaciation during the Younger Dryas Stade, and documented distribution of landforms indicative of Lateglacial permafrost (ice-wedge pseudomorphs, involutions and polygonal crop marks representing former contraction crack polygons).

$151 \times 211 \mathrm{~mm}(600 \times 600 \mathrm{DPI})$ 


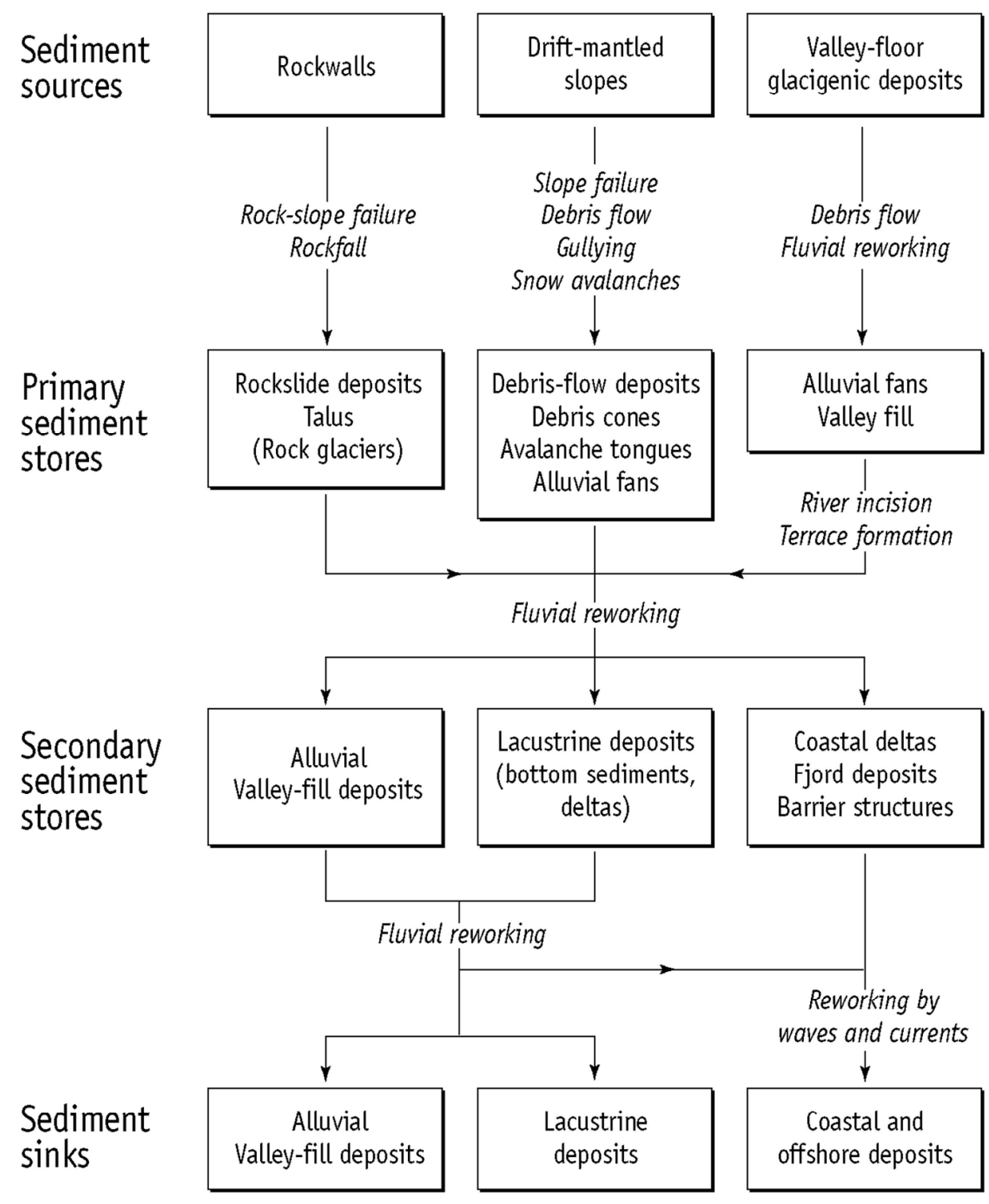

Figure 4 Simplified terrestrial paraglacial sediment cascade. Most primary sediment stores have experienced a transition from net accumulation to net erosion during the postglacial period. Adapted from Ballantyne, $\mathrm{C}$. K. (2002a) Quaternary Science Reviews 21, 1935-2017 with permission from Elsevier.

$147 \times 180 \mathrm{~mm}(300 \times 300 \mathrm{DPI})$ 

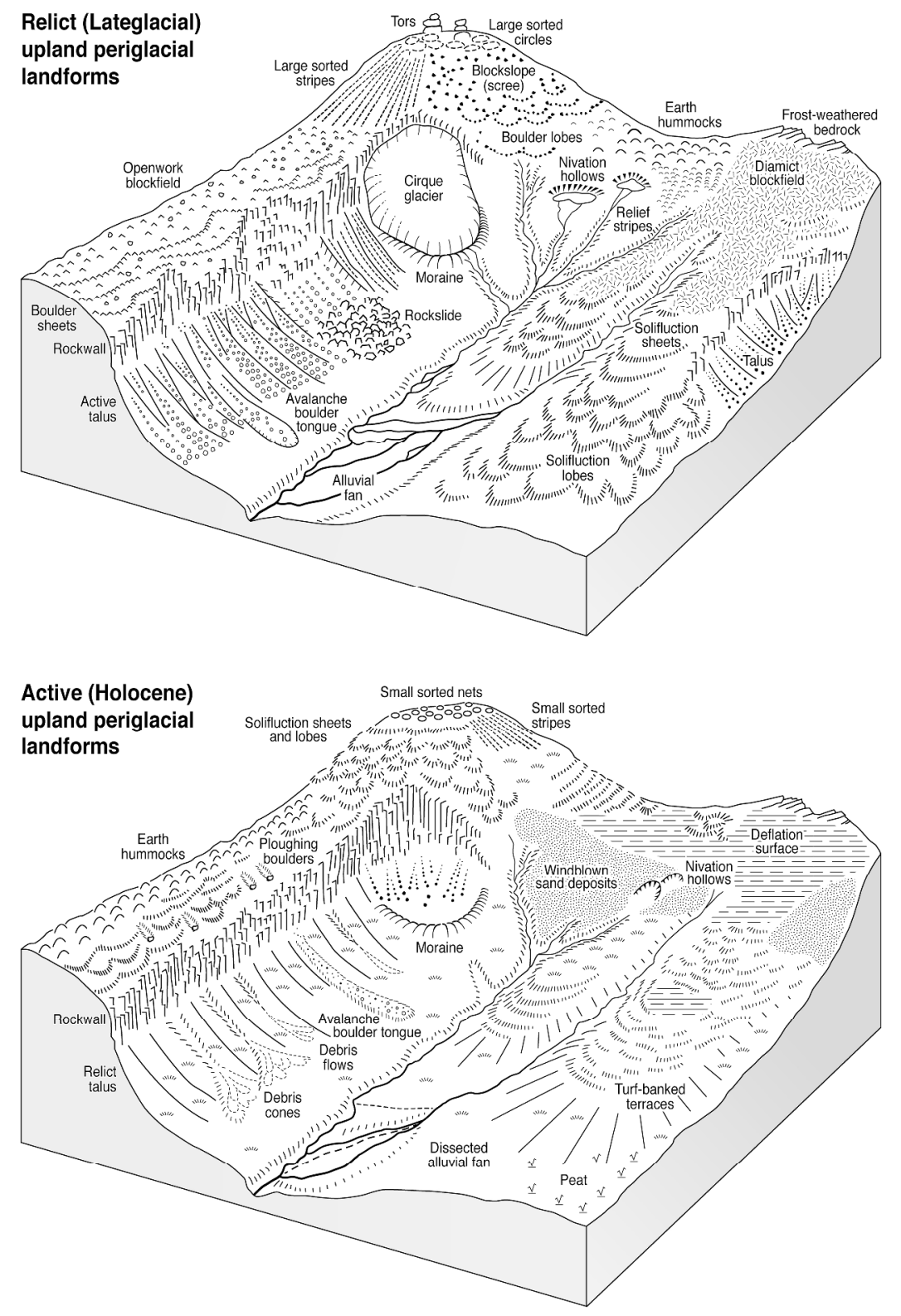

Figure 5 (a) Schematic illustration of periglacial and paraglacial landforms that developed on Scottish mountains during the Lateglacial period. (b) Schematic illustration of the range of Holocene (active) periglacial landforms on Scottish mountains. Because some landforms are restricted by regolith characteristics and hence by underlying lithology, the full range of Lateglacial or Holocene features is unlikely to be present on any single massif.

$165 \times 249 \mathrm{~mm}(600 \times 600 \mathrm{DPI})$ 

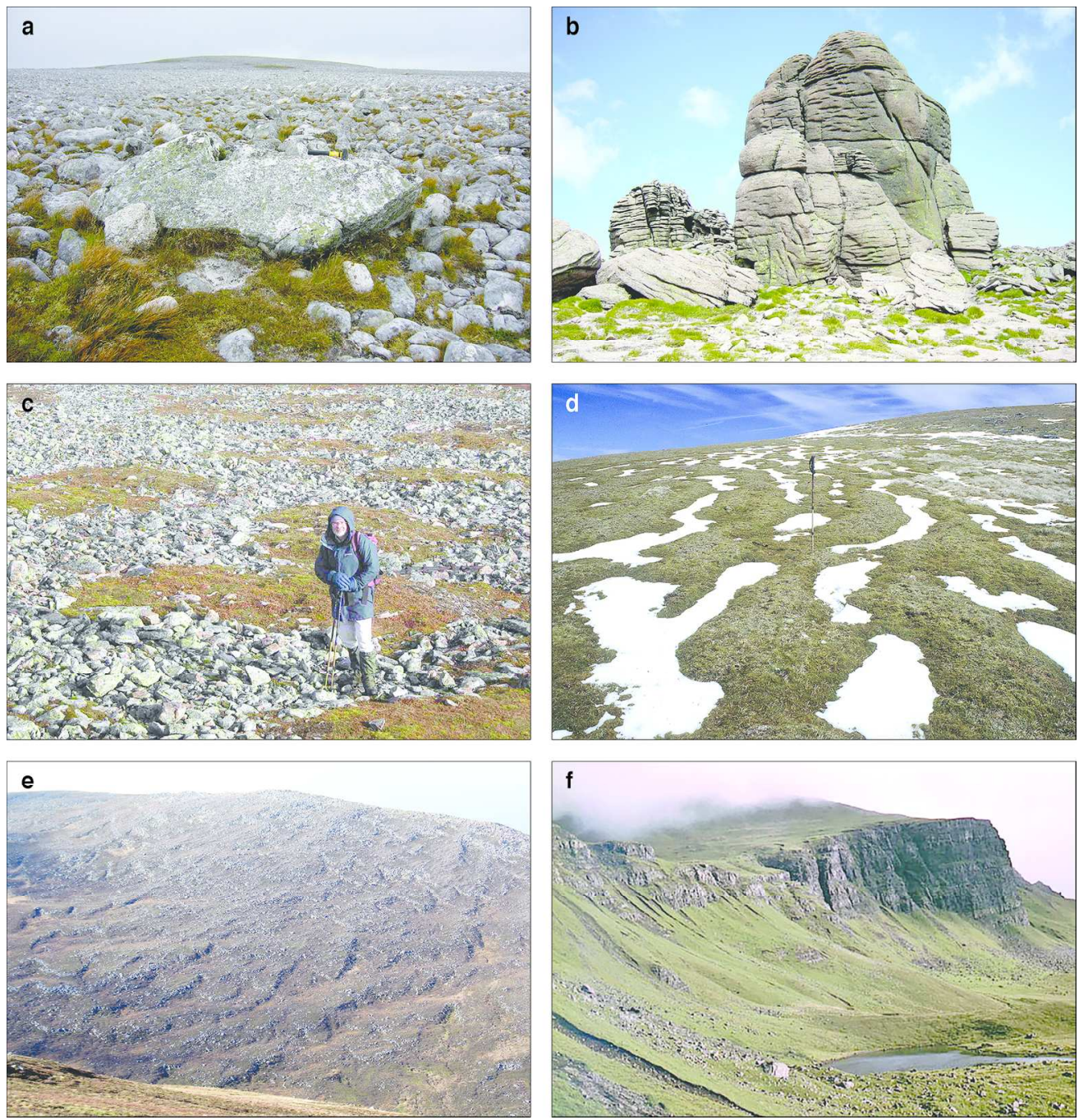

Figure 6 (a) Summit blockfield, Stob Bàn, NW Highlands. The large boulder is a quartzite erratic. (b) Tors at the summit of Beinn Mheadhoin, Cairngorms. The tor in the foreground is over $10 \mathrm{~m}$ high. (c) Large relict sorted circles, Glas Maol, SE Grampians. (d) Relict nonsorted relief stripes, Seana Braigh, NW Highlands. (e)

Boulder lobes, Cairngorms. (f) Relict vegetated talus accumulations incised by debris flows, Trotternish, northern Skye.

$156 \times 162 \mathrm{~mm}(300 \times 300 \mathrm{DPI})$ 


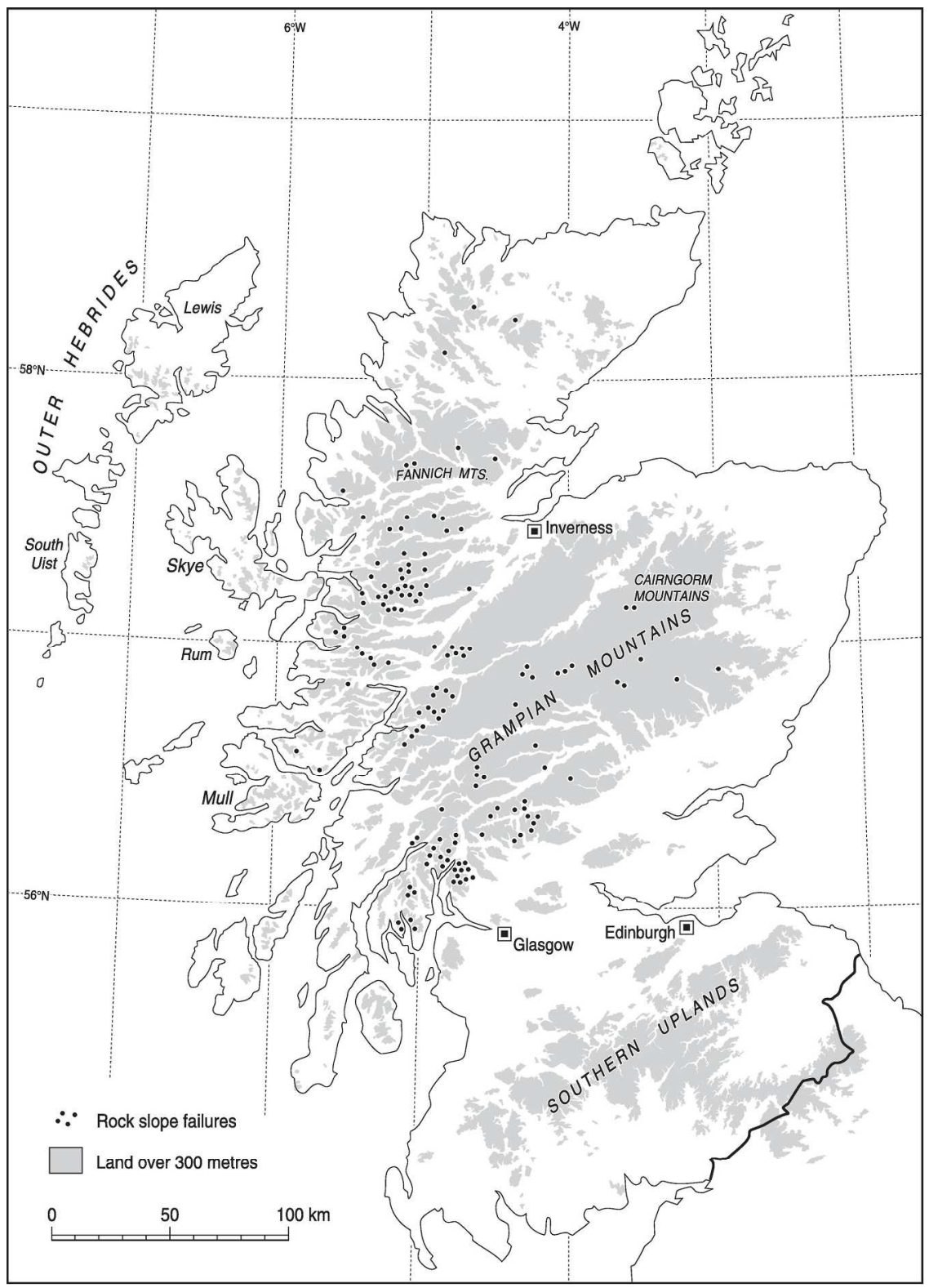

Figure 7 Distribution of documented postglacial rock-slope failures $>0.25 \mathrm{~km} 2$ in the Scottish Highlands, almost all of which occurred on schists. Large postglacial RSFs in the Southern Uplands and Hebrides are not included, nor are debris-free scarps from which runout debris was removed by glacier ice during the YDS. Adapted from Jarman, D. (2006) Engineering Geology 83, 161-182, with permission from Elsevier.

$195 \times 271 \mathrm{~mm}(300 \times 300 \mathrm{DPI})$ 

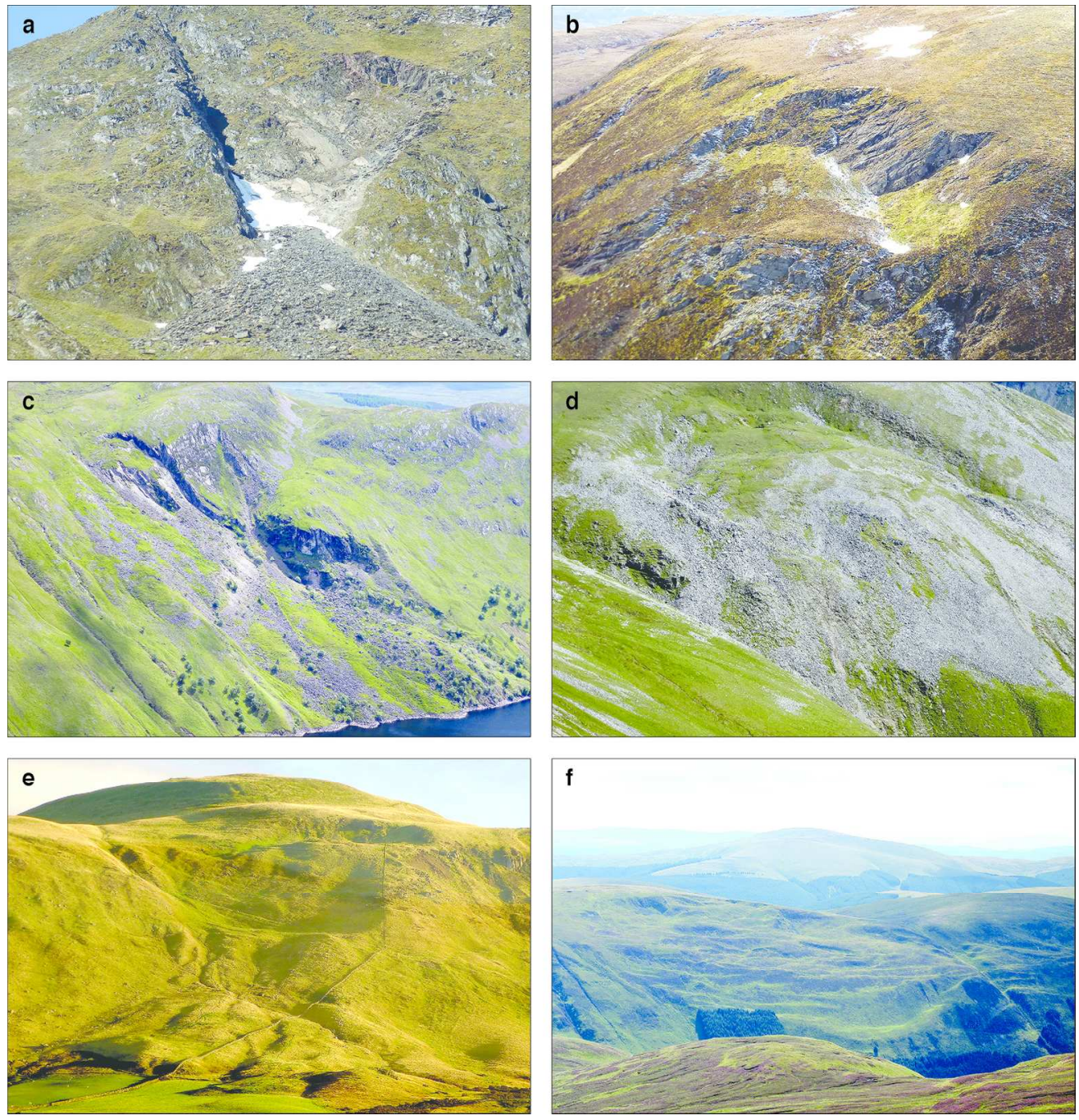

Figure 8 Examples of postglacial rock-slope failures in Scotland. (a) Recent rockslide and runout debris, Am Bodach, Mamore Mountains [NN 179649]. (b) Arrested rockslide, Tom na Caillich, Northern Highlands [NH 440656]. (c) Complex rockslide, Loch Ericht [NN 530687]. (d) Arrested rockslide, Geal Charn, central Grampians [NN 468738]. (e) Hoglayers RSF and runout lobes, West Lomond Hill, Fife [NO 194071]. (f) Large rock-slope deformation, Bell Crag, Tweedsmuir Hills, Southern Uplands [NT 181128].

$156 \times 162 \mathrm{~mm}(300 \times 300 \mathrm{DPI})$ 

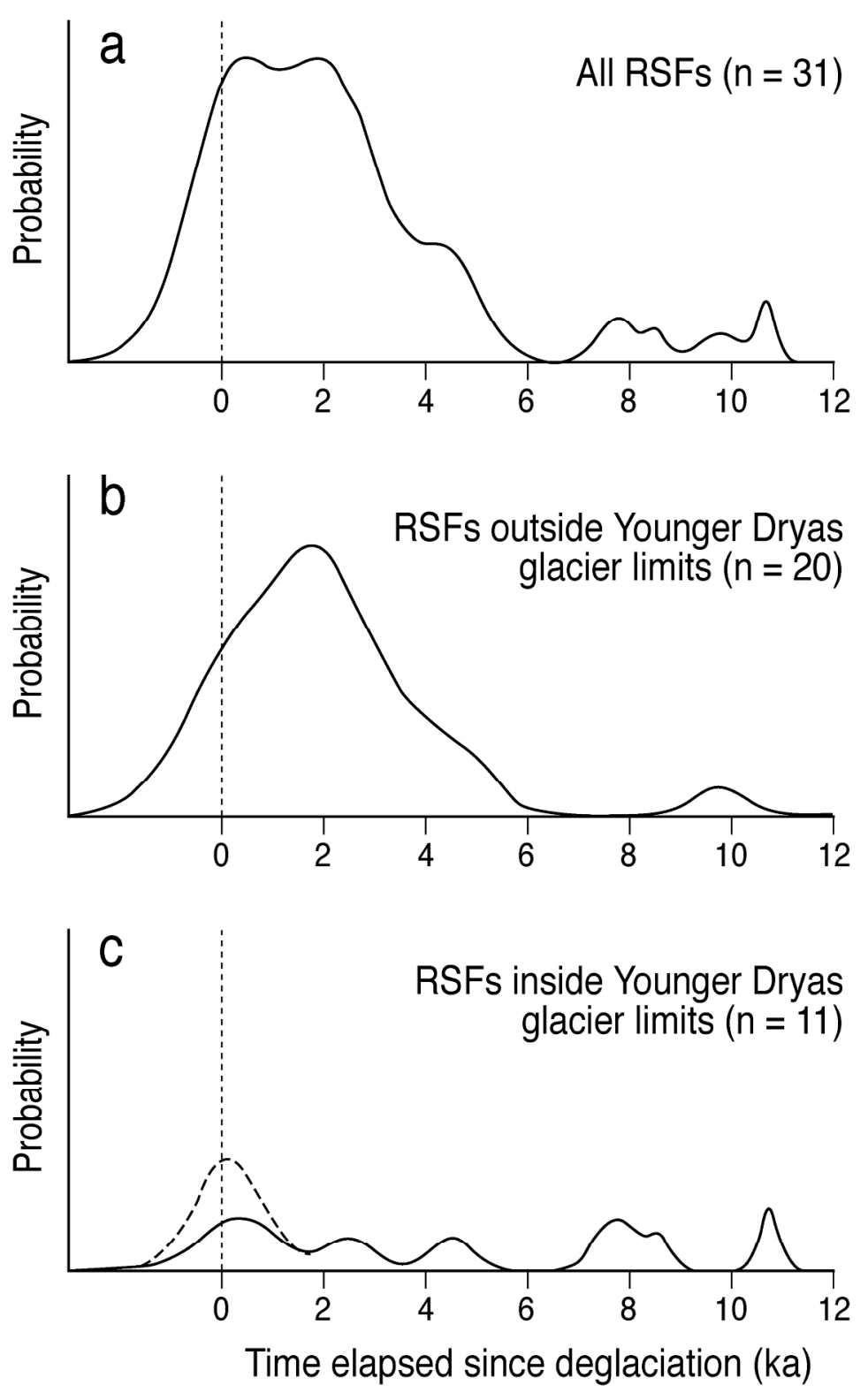

Figure 9 Summed normal kernel density estimates generated by 31 RSF ages from Scotland (22) and NW Ireland (9), calculated as time elapsed since deglaciation. (a) All RSFs. (b) RSFs outside the YDS glacier limits. (c) RSFs inside the YDS glacier limits. Extension of curves to the left of 0 ka is an artefact of curve generation. From Ballantyne et al. (2014a) Quaternary Science Reviews 86, 144-157. Reproduced with permission.

$87 \times 142 \mathrm{~mm}(600 \times 600 \mathrm{DPI})$ 

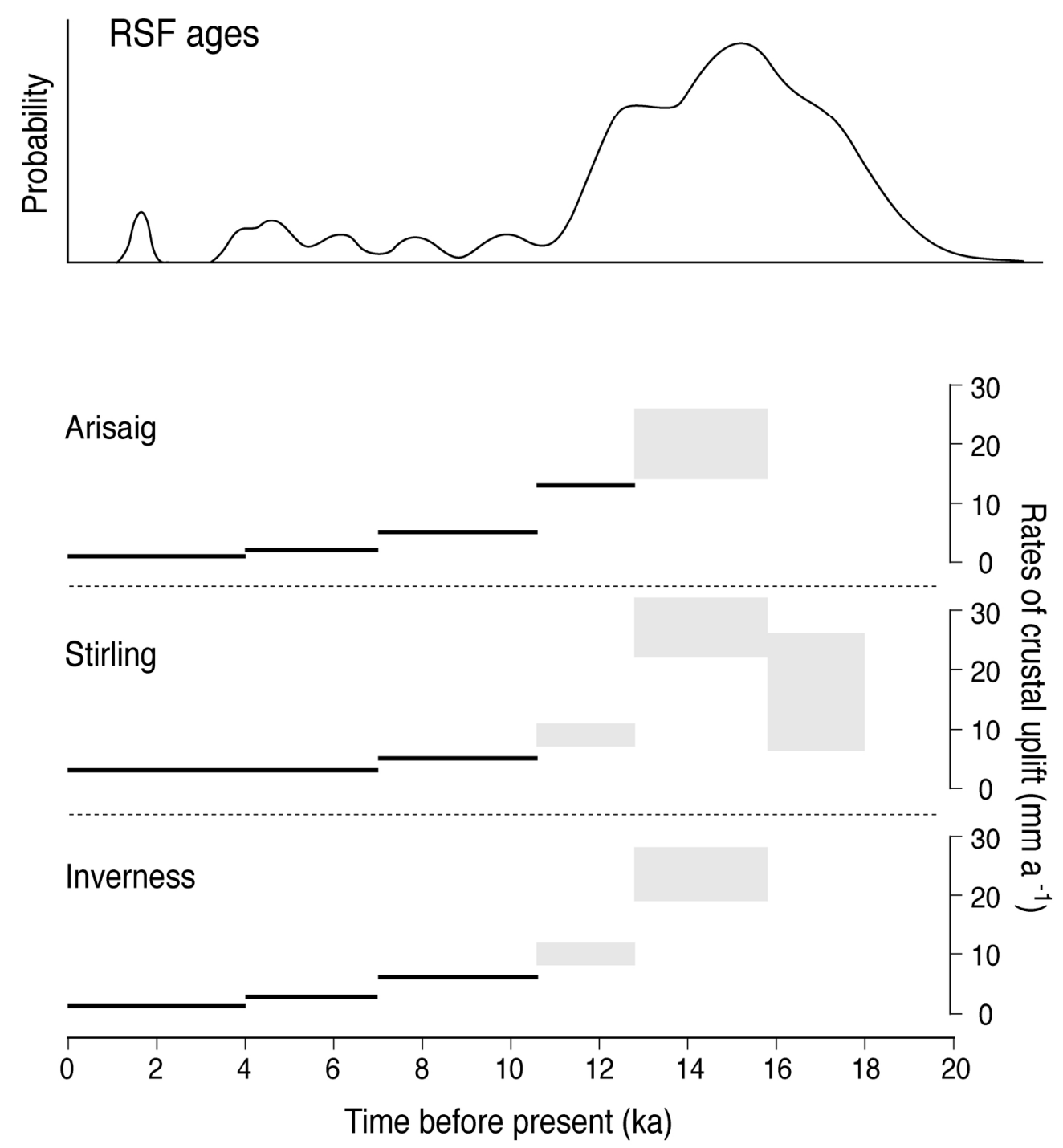

Figure 10 Summed normal kernel density estimates for 31 dated catastrophic RSFs in Scotland and NW Ireland plotted against rates of glacio-isostatic uplift for three coastal locations in Scotland. Crustal uplift data are from Firth \& Stewart (2000). From Ballantyne et al. (2014a) Quaternary Science Reviews 86, 144157. Reproduced with permission

$95 \times 103 \mathrm{~mm}(600 \times 600 \mathrm{DPI})$ 

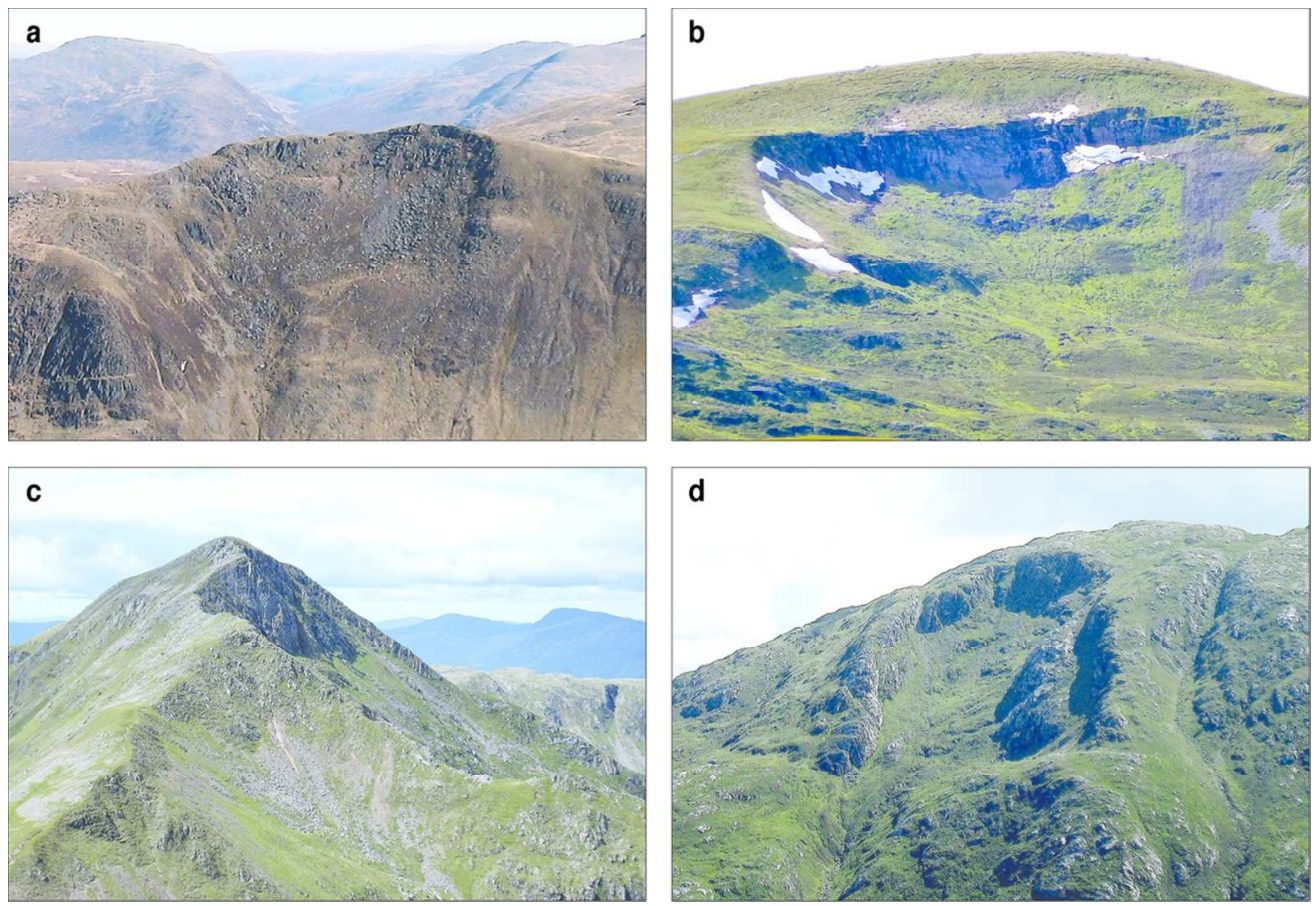

Figure 11 Examples of debris-free scarps representing the sites of Lateglacial rockslides from which debris was removed by glacier ice during the Loch Lomond Readvance. (a) Coire Sgriodain, western Grampians [NN 355745]. (b) Coire Sron an Nid, central Grampians [NN 522772]. (c) Coire Sgréamhach, Sgorr Donuill, Western Grampians. (d) Coire Mhic Eacharna, Ardgour [NM 929634].

$103 \times 70 \mathrm{~mm}(300 \times 300 \mathrm{DPI})$ 


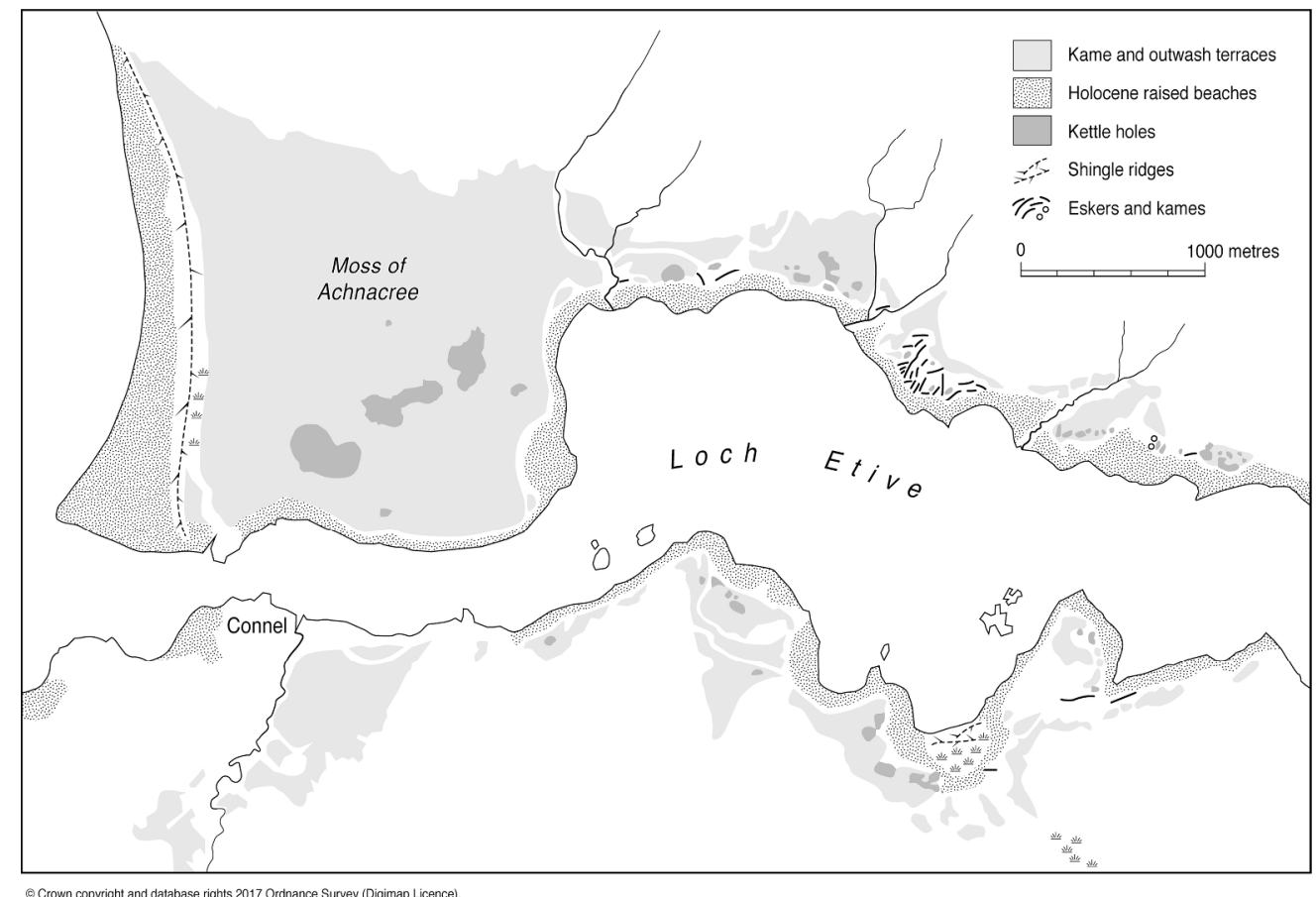

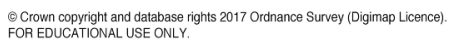

Figure 12 Kettled kame terraces formed at the margin of a YDS glacier merging westward into a large kettled outwash terrace (Moss of Achnacree) graded to a Lateglacial sea level of 10-12 m above present at the mouth of Loch Etive. Adapted from Gray, J. M. (1975) Proceedings of the Geologists' Association 86, 227-238.

$120 \times 84 \mathrm{~mm}(600 \times 600 \mathrm{DPI})$ 


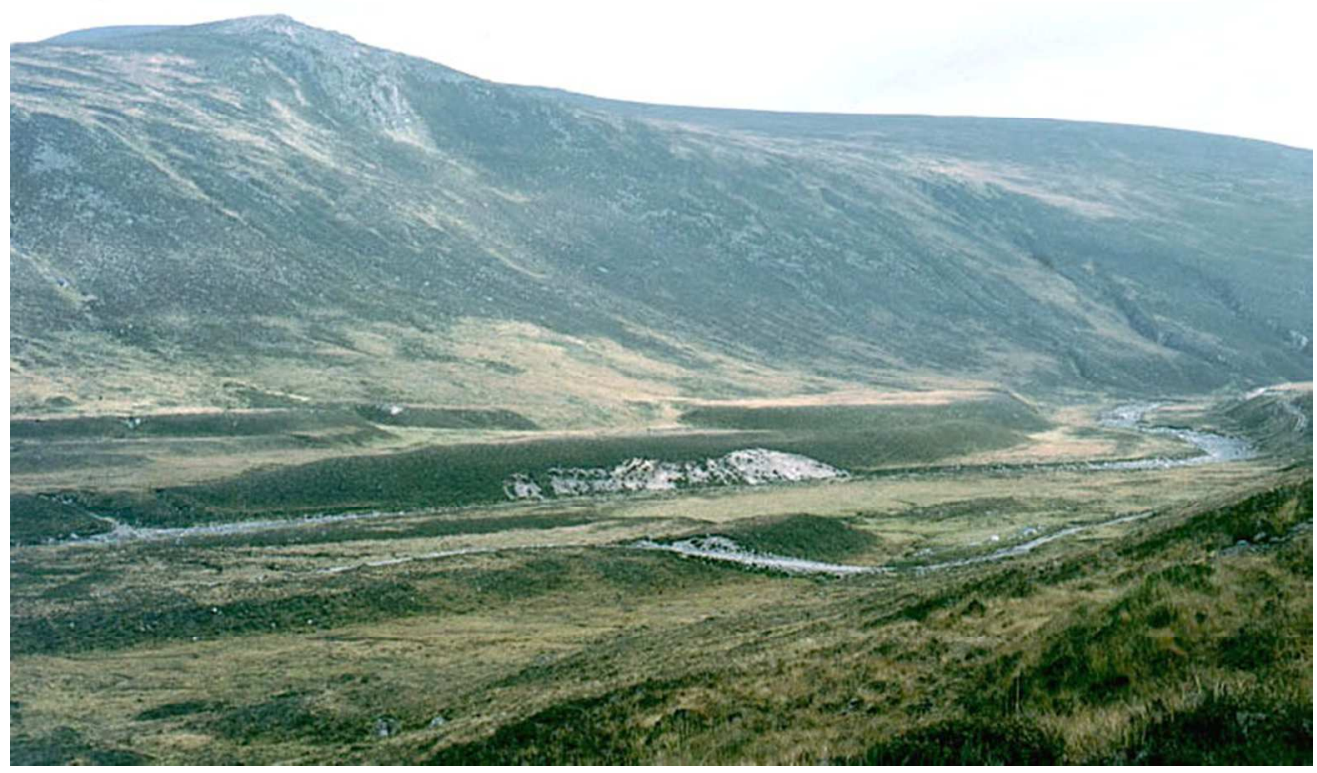

Figure 13 Terraces in Glen Dee, Cairngorms. The higher terraces rise over $10 \mathrm{~m}$ above the present floodplain, and represent postglacial incision of outwash deposited during glacier retreat around $\sim 16.5-15.5$ ka. The low terrace adjacent to the present floodplain is probably late Holocene in age.

$275 \times 164 \mathrm{~mm}(72 \times 72 \mathrm{DPI})$ 

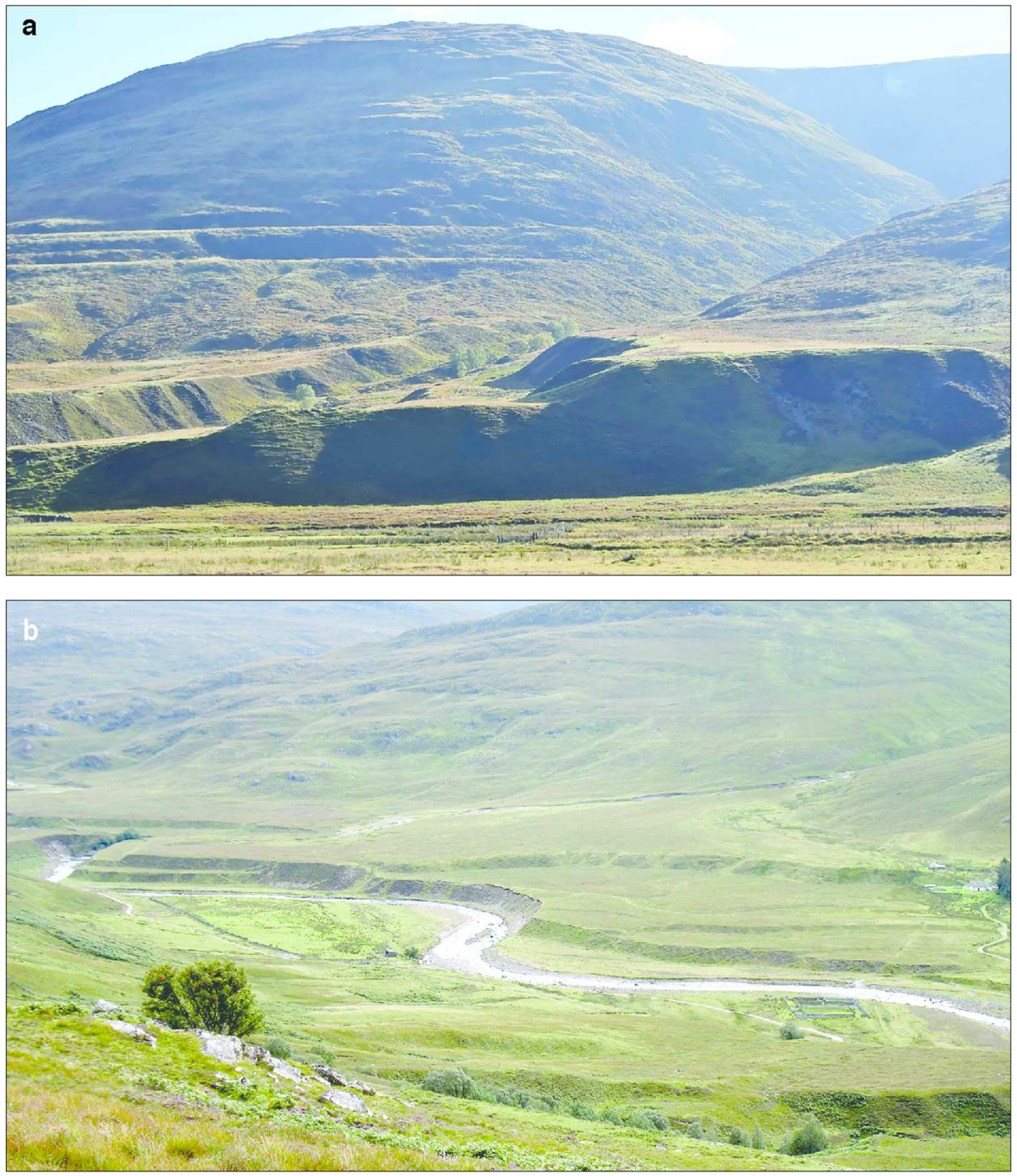

Figure 14 Lateglacial alluvial fans in Glen Roy. (a) The Brunachan fan, showing later terraces inset into the original fan and the two highest lake shorelines (at $325 \mathrm{~m}$ and $350 \mathrm{~m} \mathrm{OD)}$ ) in the background. (b) The Annat fan in upper Glen Roy, showing how terraces formed by incision of the River Roy have cut back into the distal part of the original fan.

$120 \times 139 \mathrm{~mm}(300 \times 300 \mathrm{DPI})$ 

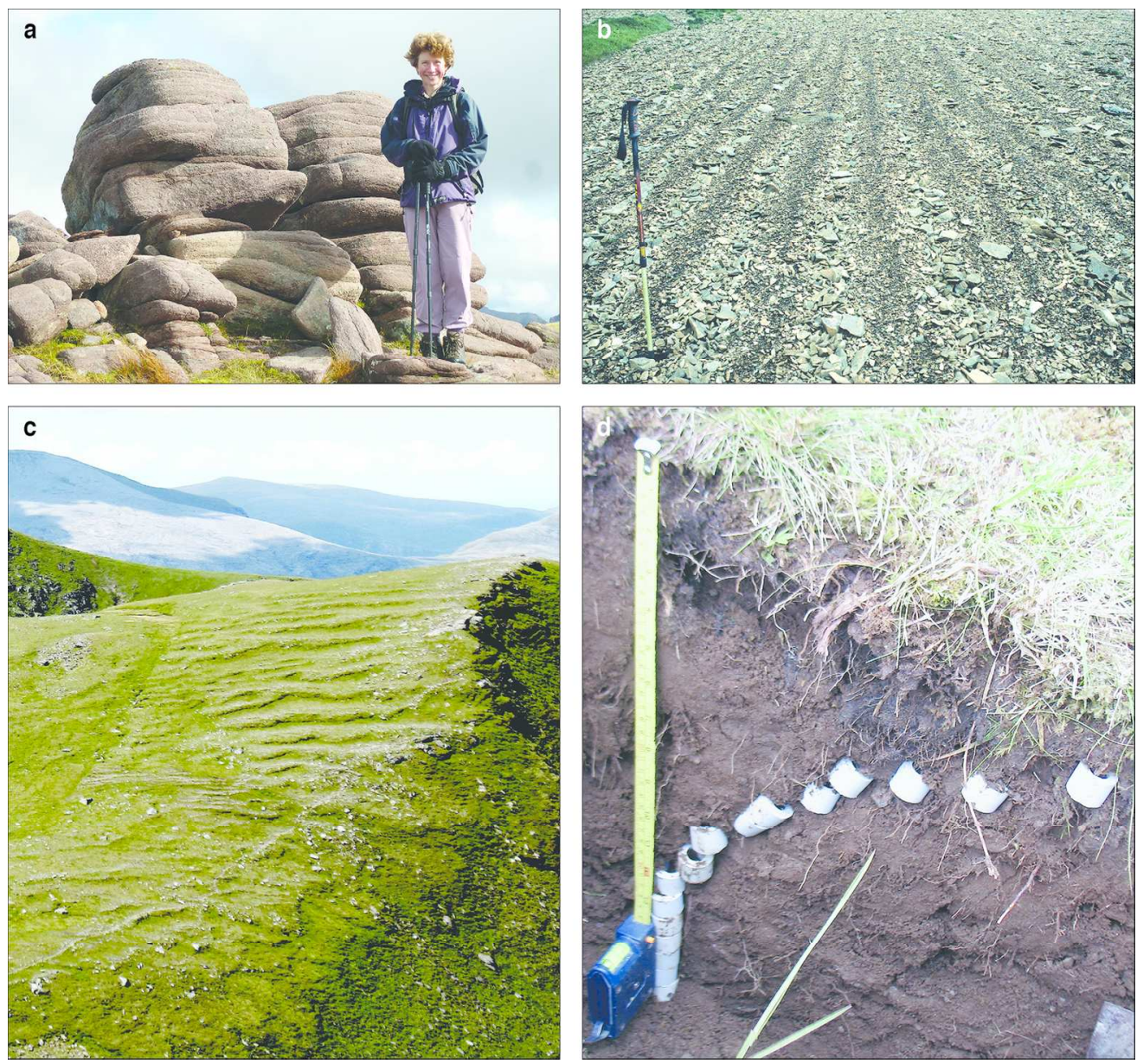

Figure 15 (a) Summit outcrop of Torridon Sandstone rounded by granular disaggregation, Beinn Dearg, Torridon. (b) Active sorted stripes, Tinto Hill, Southern Uplands. (c) Active solifluction terraces, Tom a' Choinnich, Fannich Mountains, NW Highlands. (d) Displacement of segmented columns by solifluction over 35 years, Fannich Mountains, NW Highlands.

$140 \times 130 \mathrm{~mm}(300 \times 300 \mathrm{DPI})$ 

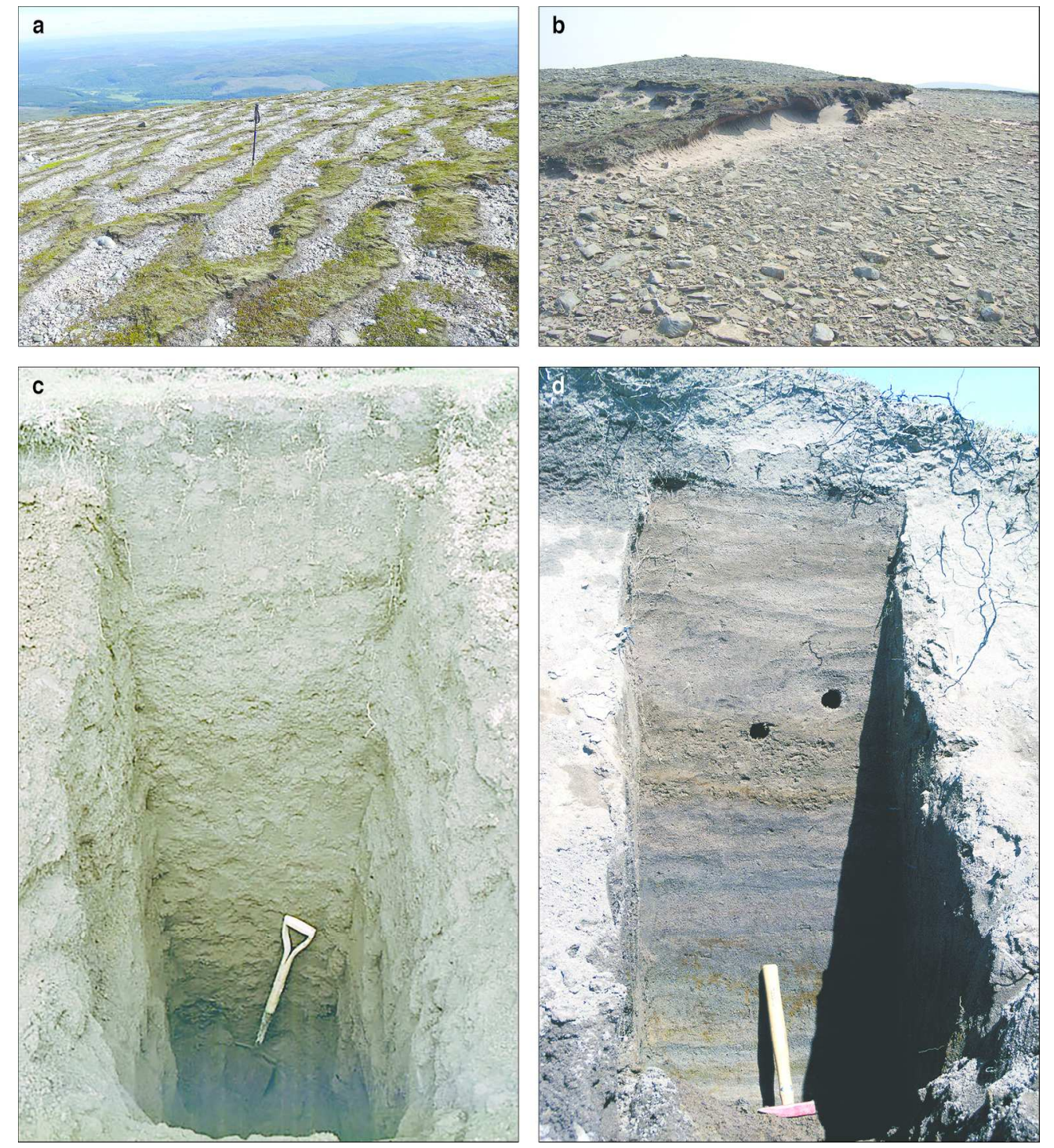

Figure 16 Holocene aeolian landforms on high ground. (a) Wind stripes on Beinn a'Bhach-Ard, NW Highlands. (b) Deflation surface and residual island of eroding windblown sand, Ward Hill, Orkney. (c) Pit excavated through aeolian deposits $2.9 \mathrm{~m}$ deep on the summit of The Storr, Trotternish, Skye. (d) Section through plateau-margin aeolian sands, An Teallach, showing unweathered upper sand unit overlying lower weathered sand unit; the boundary lies between the two circular holes, from which samples for OSL dating were extracted.

$167 \times 185 \mathrm{~mm}(300 \times 300 \mathrm{DPI})$ 


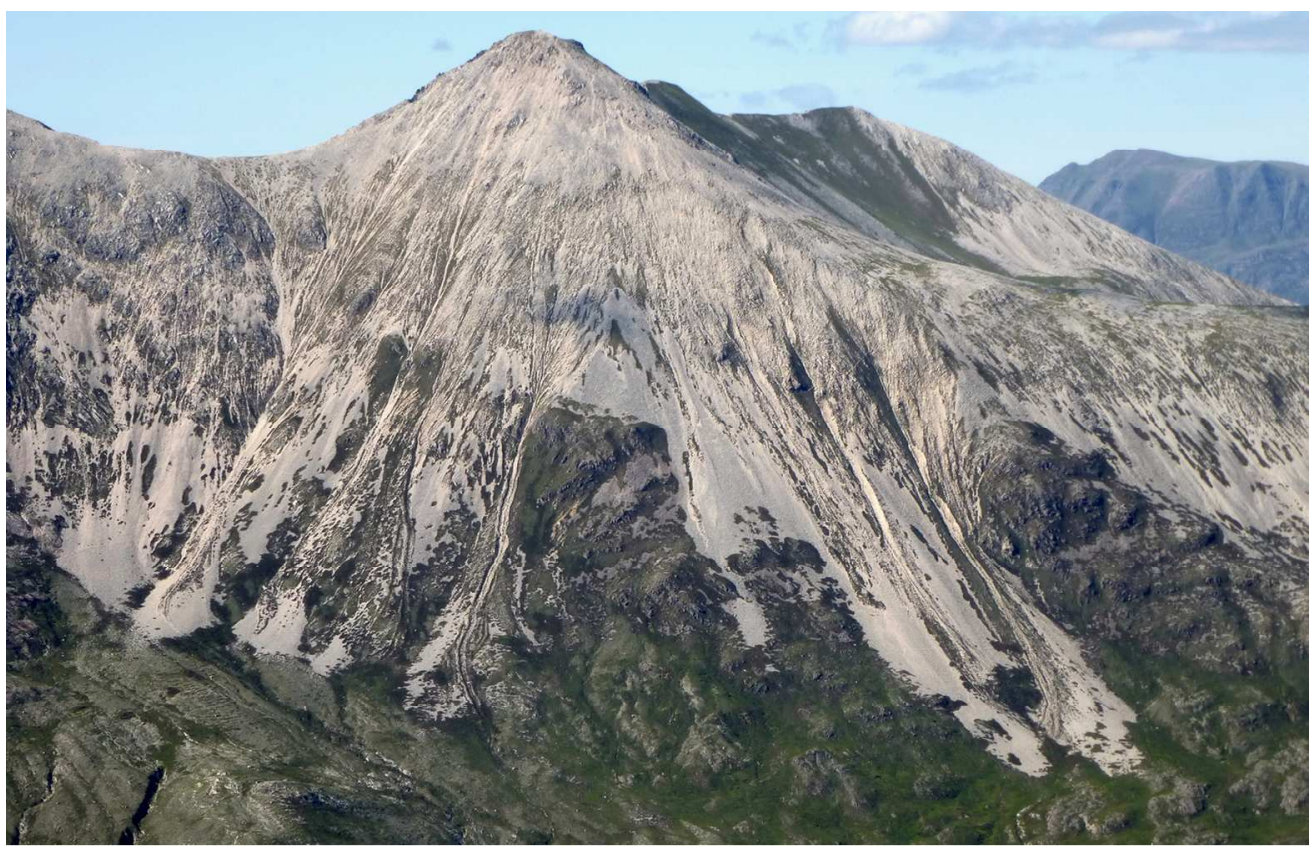

Figure 17 Debris flows on Beinn Eighe (Torridon). Successive flows have transported light-coloured quartzite debris across the subjacent darker Torridon Sandstone.

$128 \times 82 \mathrm{~mm}(300 \times 300 \mathrm{DPI})$ 

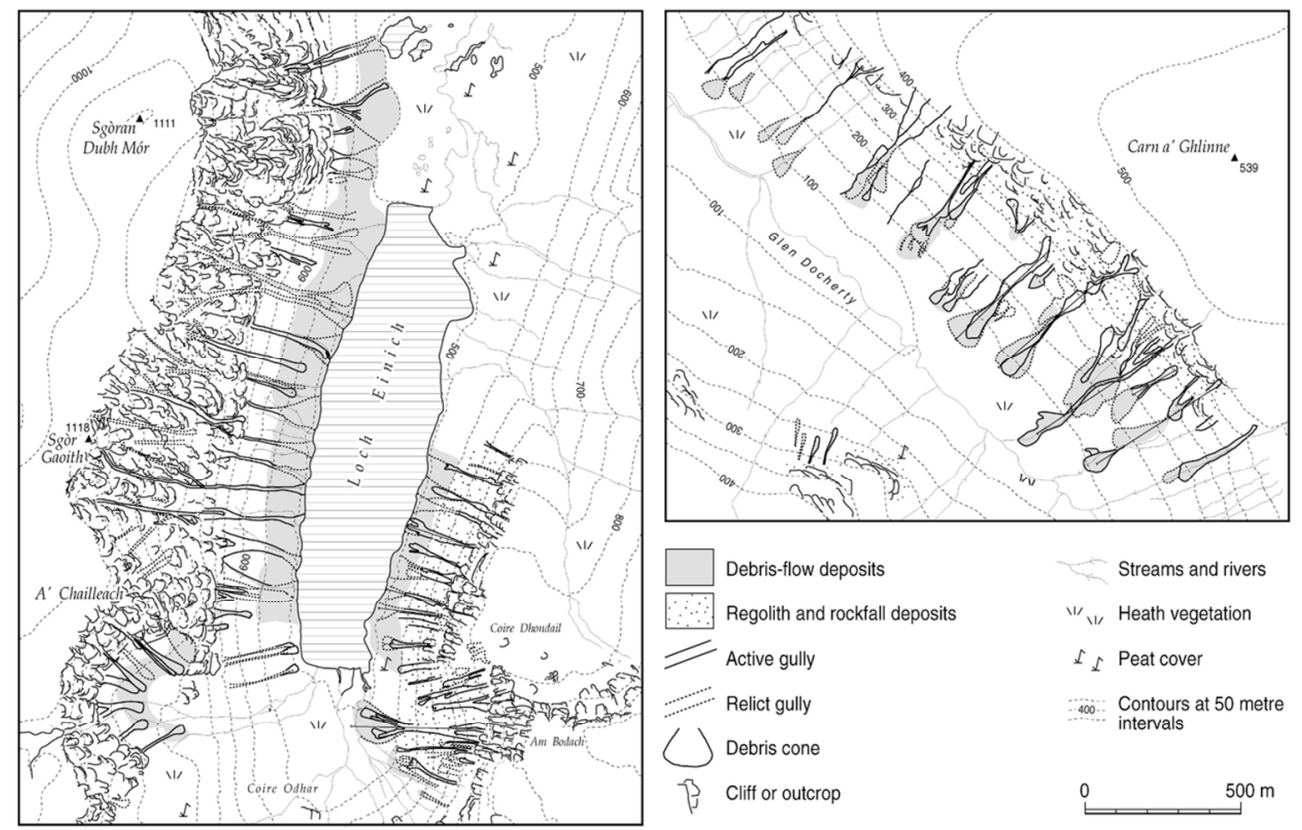

Figure 18 Debris flows and debris cones on the flanks of glacial troughs: Gleann Einich, Cairngorms (left) and Glen Docherty near Kinlochewe (right). Adapted from a map in Curry (1999a) and reproduced with the author's permission.

$107 \times 69 \mathrm{~mm}(300 \times 300 \mathrm{DPI})$ 

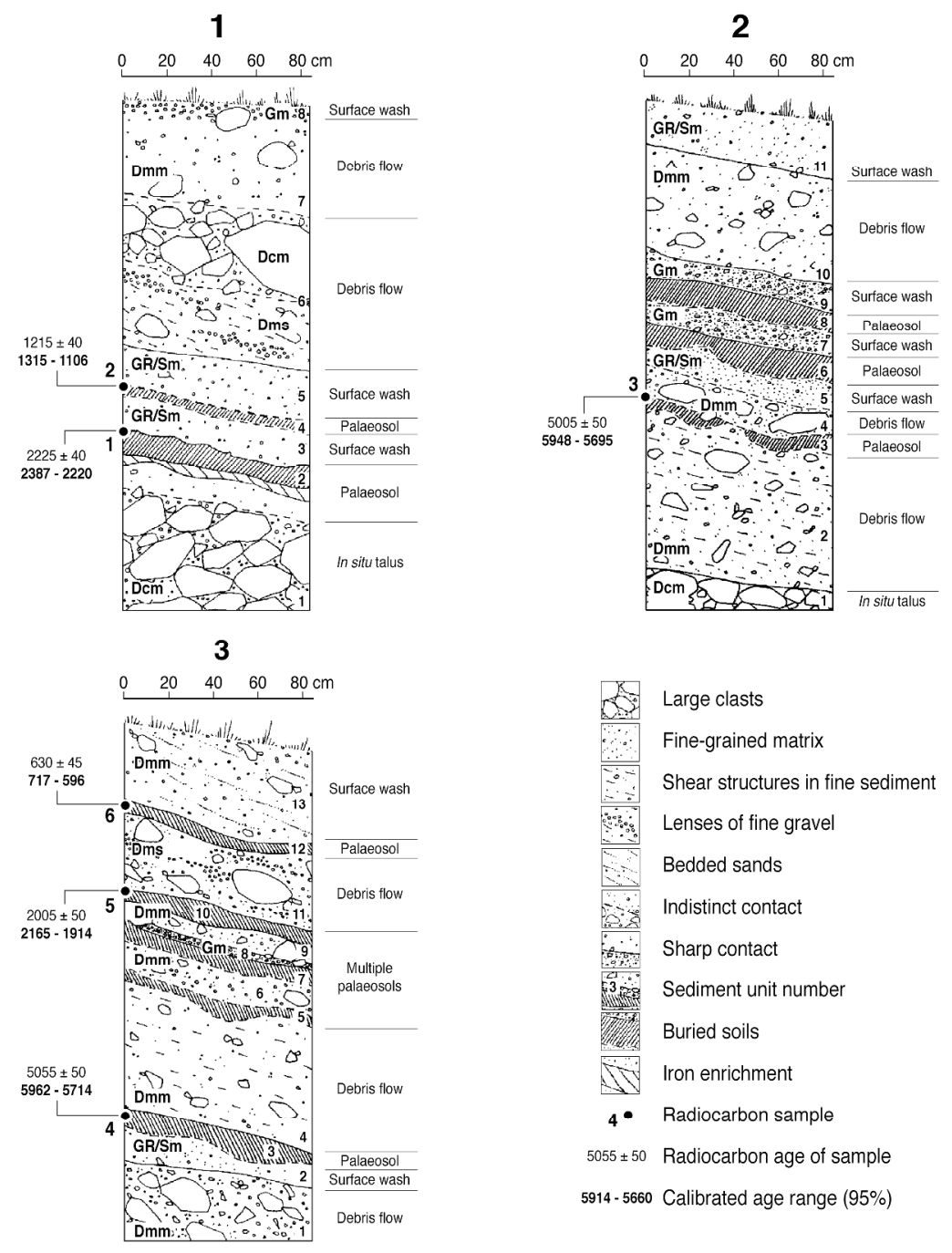

\footnotetext{
Dcm: Clast-supported diamicton, massive

Dmm: Matrix-supported diamicton, massive

Dms: Clast-supported diamicton, stratified
}

\footnotetext{
Gm: Coarsc gravcls, massivc

Gms: Matrix -supported coarse gravels

GRm: Fine gravels, massive

GR/Sm: Bedded sands and gravels
}

Figure 19 Gully-wall sections through relict talus at the southern end of the Trotternish Escarpment, Isle of Skye, showing the location of dated samples and the intervening sediment units. Gradients have been reduced for clarity. Adapted from Hinchliffe (1999).

$169 \times 261 \mathrm{~mm}(600 \times 600 \mathrm{DPI})$ 

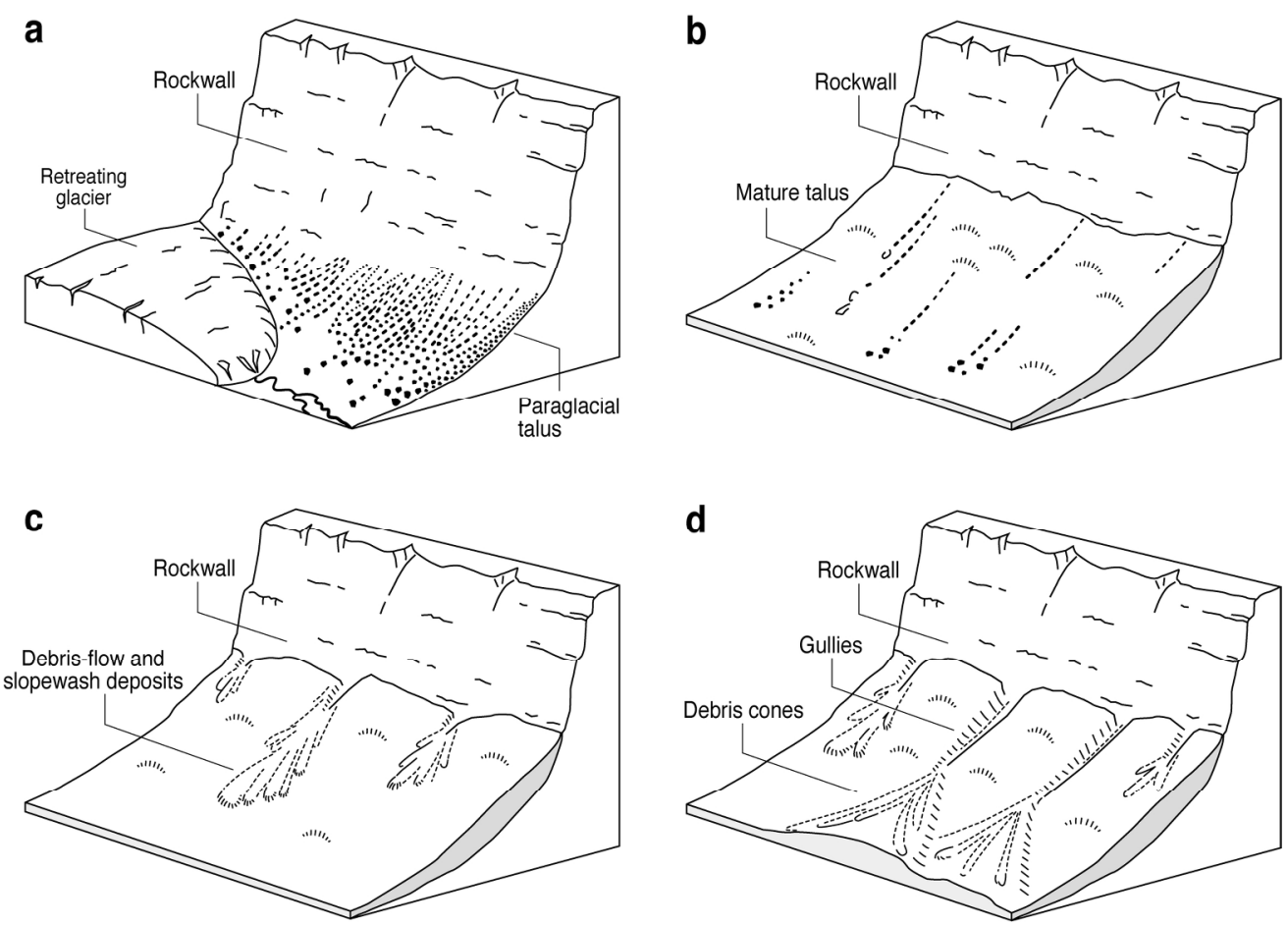

Figure 20 Model of postglacial talus evolution proposed by Hinchliffe \& Ballantyne (2009). (a) Paraglacial stress release and Lateglacial frost wedging cause frequent rockfalls and rapid talus accumulation. (b) After several millennia, progressive stabilization of the rockwall has diminished rockfall supply; soil and vegetation cover develop on the talus. (c) Localised failure and gully development at the talus crest, and redeposition of sediment by debris flows and slopewash on the upper slope. (d) Debris flows and runoff within gullies result in downslope gully extension and deposition of sediments as debris cones.

$98 \times 70 \mathrm{~mm}(600 \times 600 \mathrm{DPI})$ 


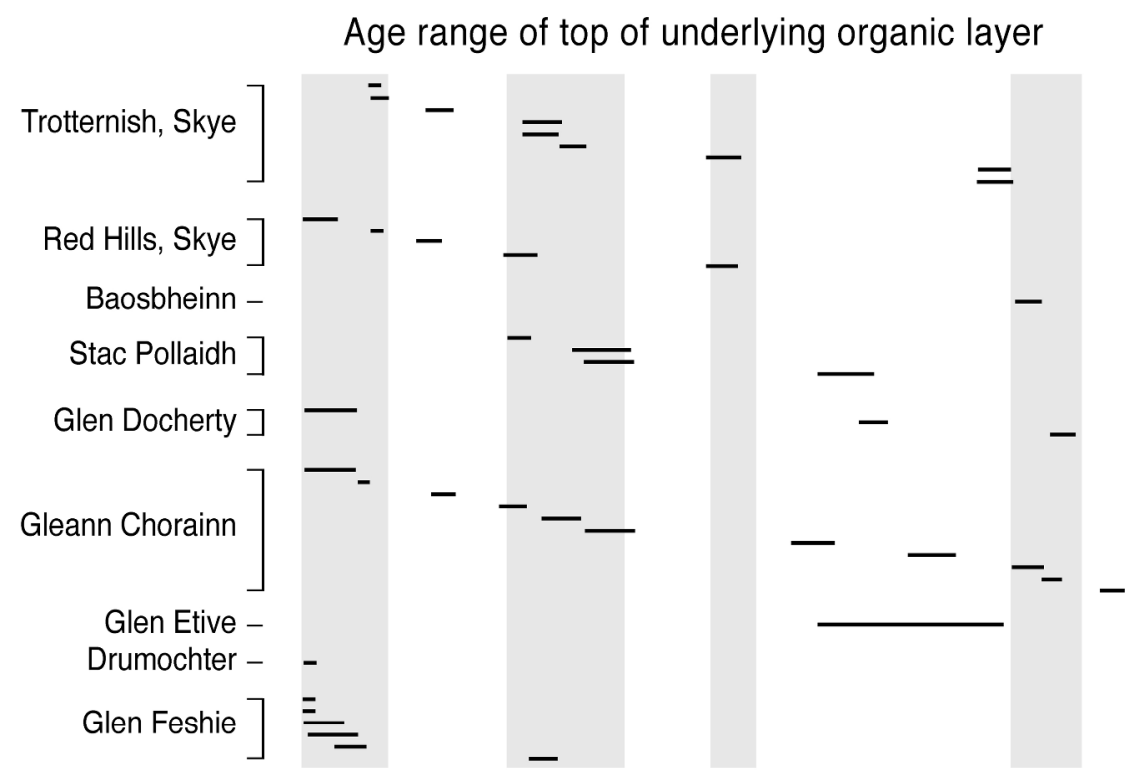

Age range of base of overlying organic layer

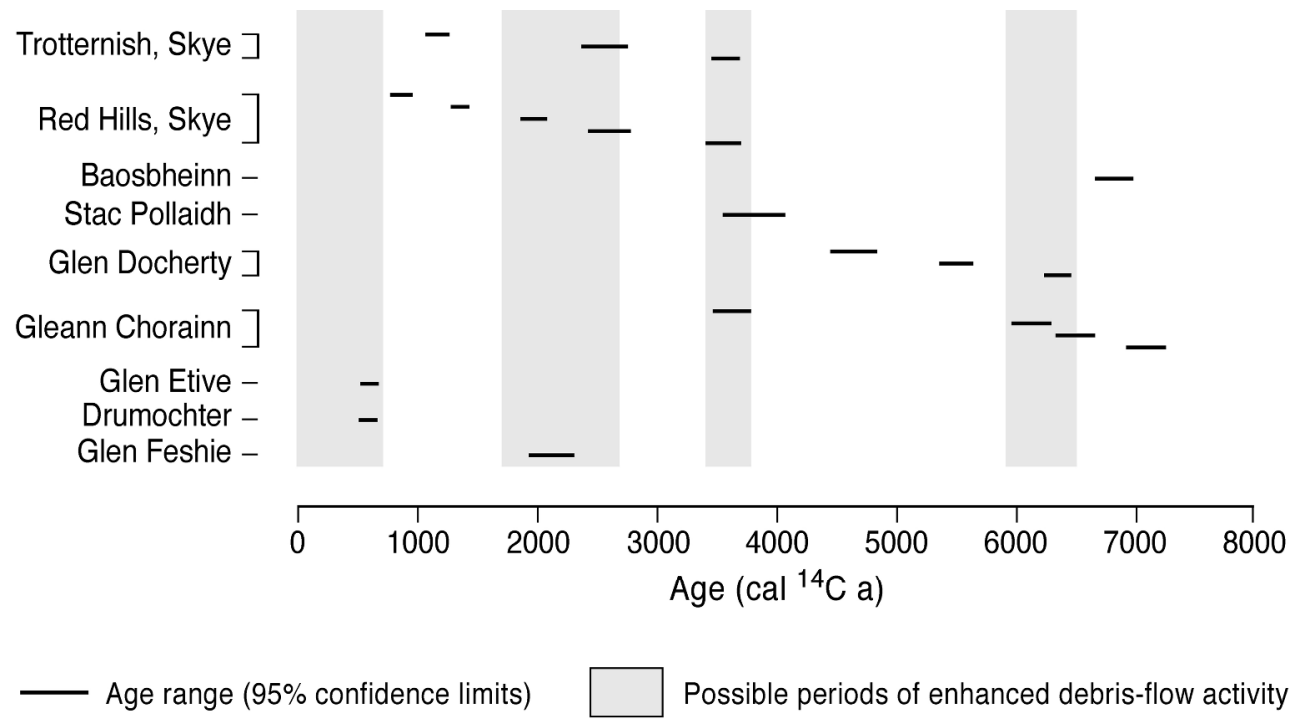

Figure 21 Calibrated radiocarbon ages relating to debris-flow units overlying or underlying organic layers at nine sites on Skye and in the Scottish Highlands, showing possible periods of enhanced activity. The horizontal bars represent the $95 \%$ confidence limits for each calibrated age. Sources: Brazier et al. (1988); Brazier \& Ballantyne (1989); Curry (2000a, 2000b); Reid \& Thomas (2006); Hinchliffe \& Ballantyne (2009).

$129 \times 159 \mathrm{~mm}(600 \times 600 \mathrm{DPI})$ 

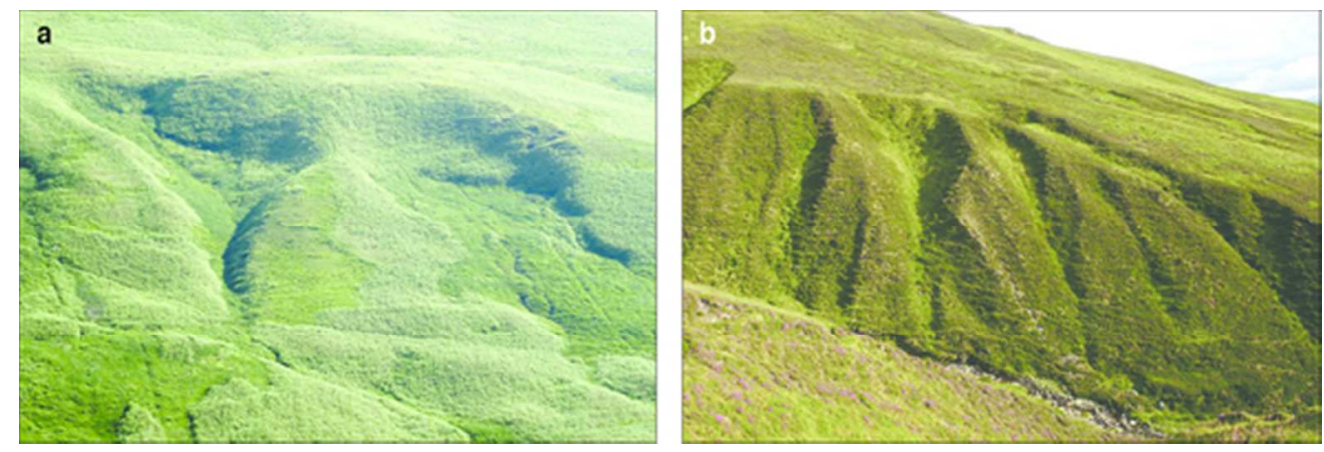

Figure 22 (a) Cuspate scars representing former translational landslides in till deposits, Glen Artney, southern Grampians. (b) Gullies eroded in till bluffs, Carn Bhan, northern Highlands. Many such gullies were initiated as translational landslides then modified by stream erosion.

$50 \times 16 \mathrm{~mm}(300 \times 300 \mathrm{DPI})$ 


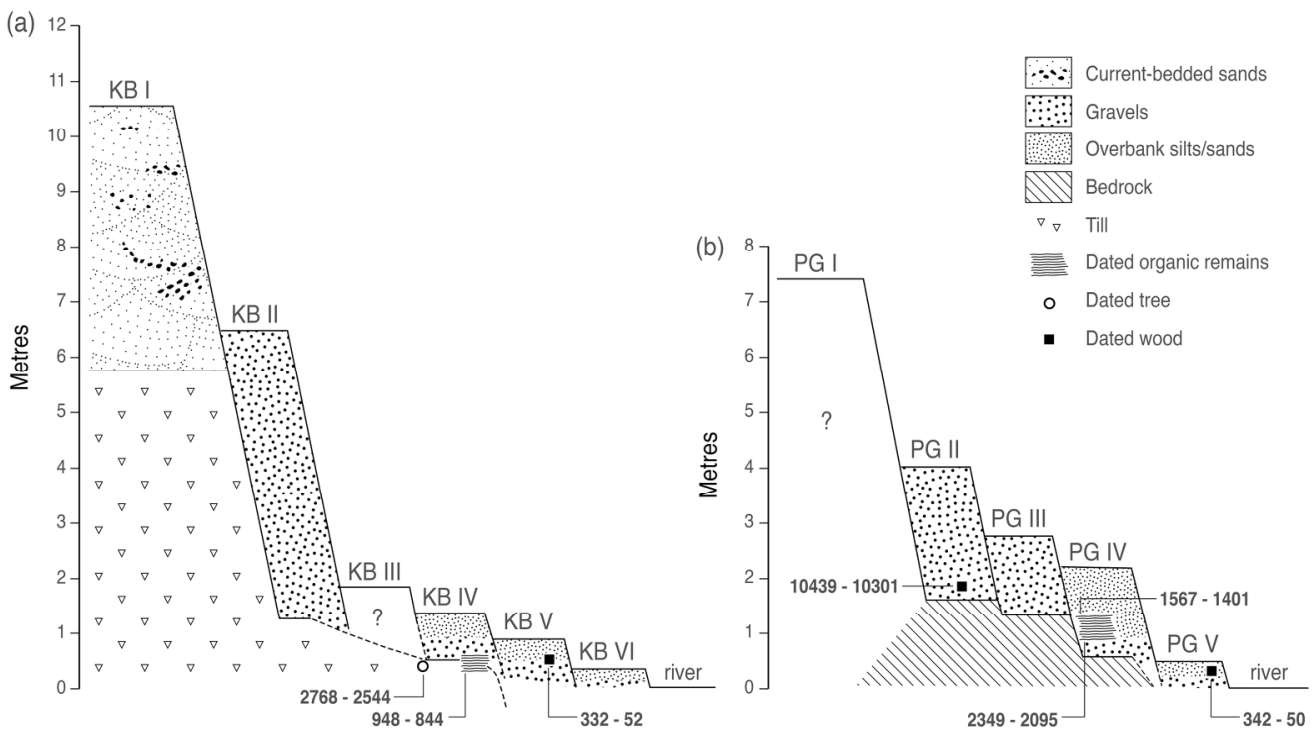

Figure 23 Schematic illustration of river terraces in the Kirtle Water catchment and associated radiocarbon ages of dated organic material. (a) Terraces KB I to KB VI of the Kirk Burn near its confluence with Kirtle Water. (b) Terraces PG I to PG V of the middle reach of Kirtle Water near Palmersgill Bridge. The figures represent calibrated $\pm 1 \sigma$ age ranges (cal $14 \mathrm{C}$ a) of radiocarbon dates, referenced to $A D 2000$. Adapted from Tipping (1995b).

$94 \times 52 \mathrm{~mm}(600 \times 600 \mathrm{DPI})$ 


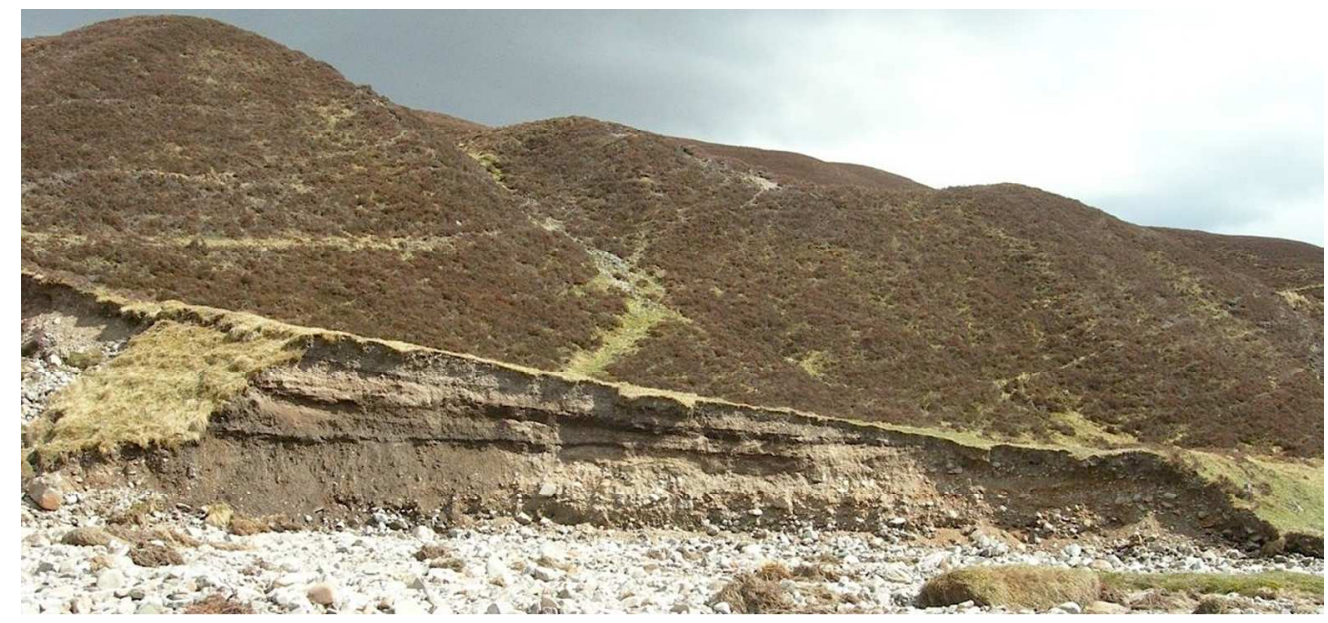

Figure 24 Exposure on a small Holocene alluvial fan, the Edendon Fan [NN 715776]. Three peat layers (dark layers on the photograph) extend across the entire width of the fan. Radiocarbon dating of samples from the top and base of each peat layer has demonstrated that each intervening sediment bed represents a single depositional event. The lowest peat layer has developed on a terraced floodplain that ceased to aggrade between $\sim 27$ and 24 cal 14C ka.

$107 \times 50 \mathrm{~mm}(300 \times 300$ DPI $)$ 


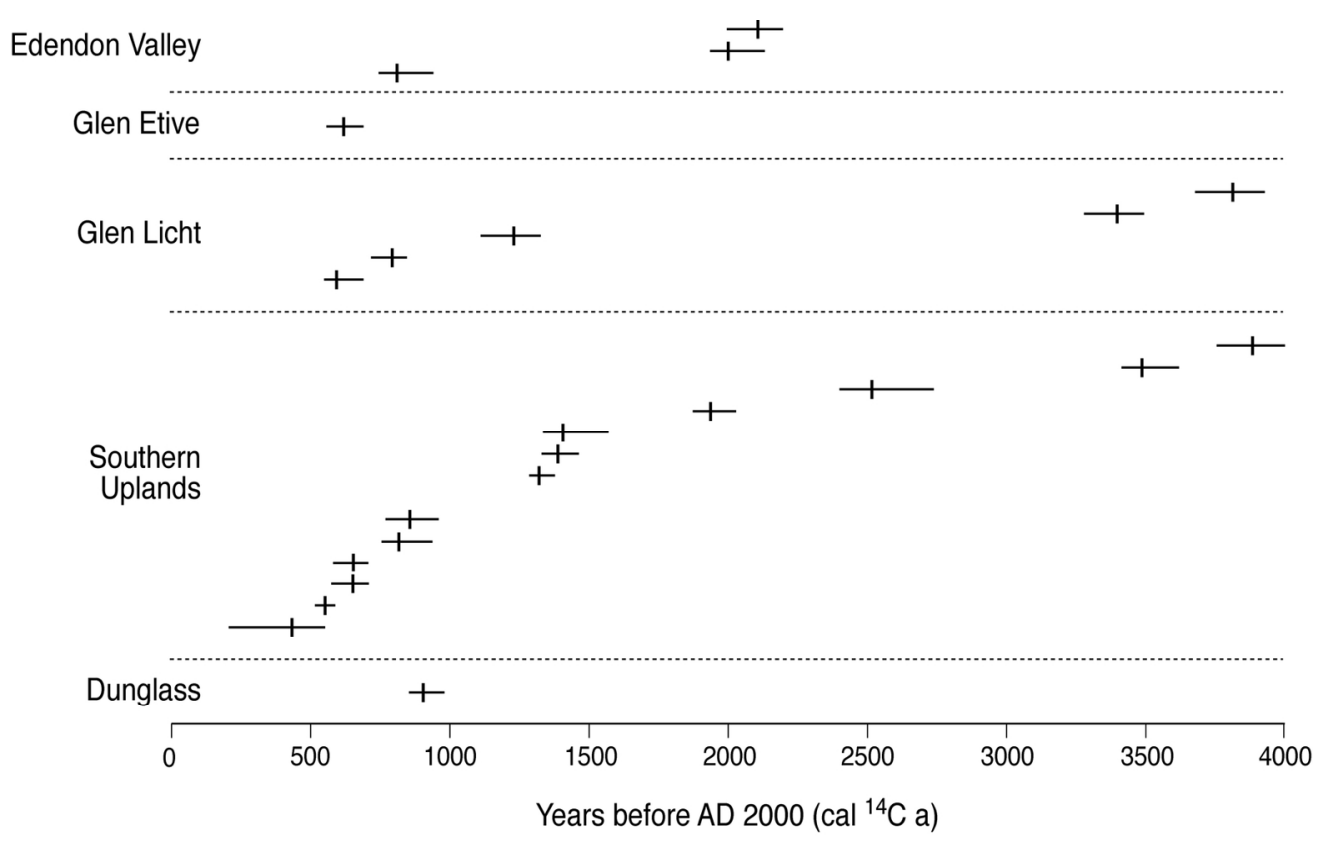

Figure 25 Calibrated radiocarbon ages relating to individual sediment deposition episodes on Holocene alluvial fans. Horizontal bars represent the $\pm 2 \sigma$ range and vertical dashes represent the median age. Dates from Glen Etive (Brazier et al. 1988), Dunglass (Tipping 2007) and most for the Southern Uplands (Foster et al. 2008) represent the onset of fan accumulation. Those for Edendon (Ballantyne \& Whittington 1999) and Gleann Licht (Reid et al. 2003) represent the onset of accumulation (oldest age) and timing of later sedimentation events.

$75 \times 47 \mathrm{~mm}(600 \times 600 \mathrm{DPI})$ 

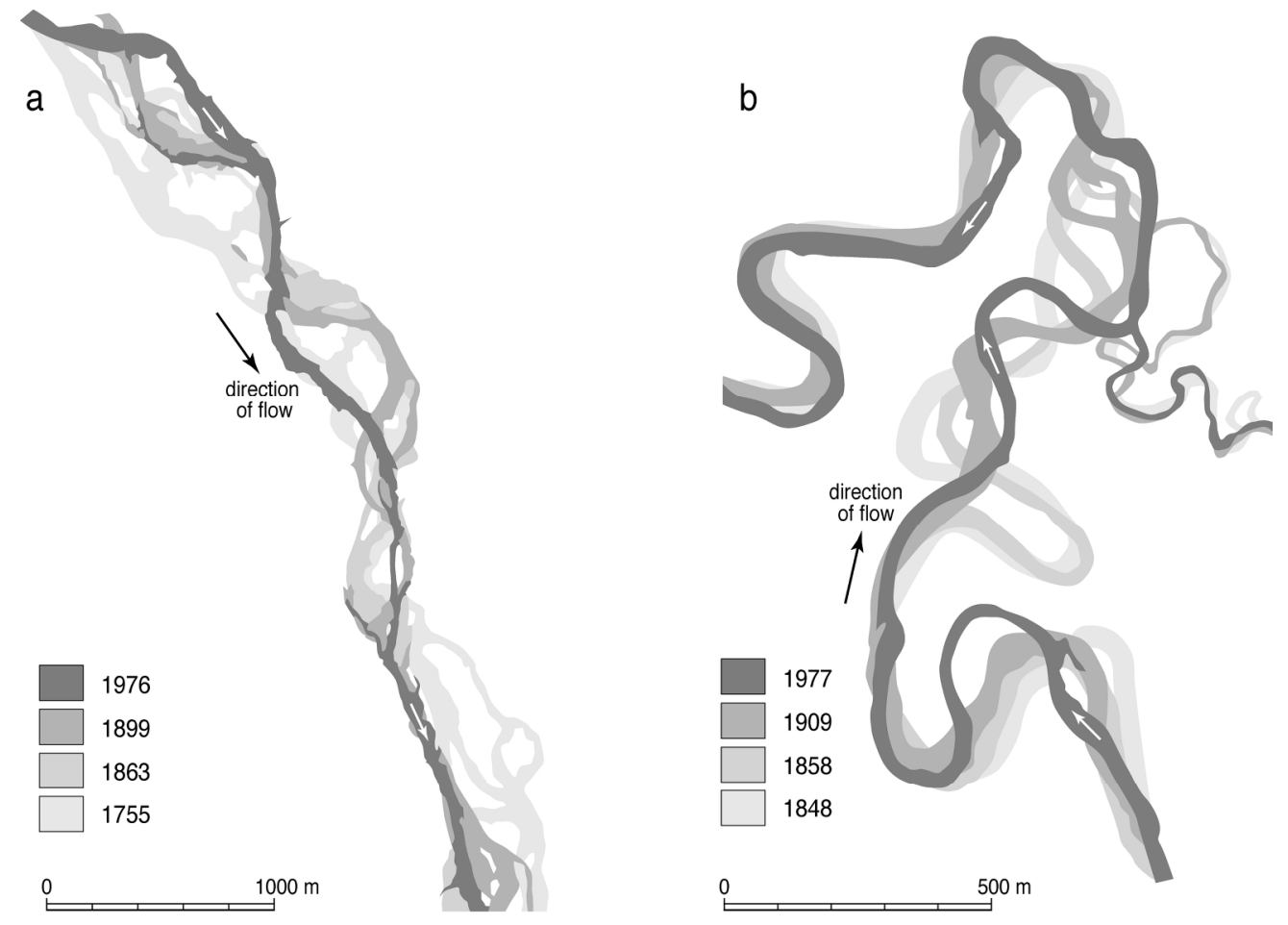

Figure 26 (a) Channel planform change of the River Tummel above its confluence with the Tay, characteristic of the behaviour of a wandering gravel-bed river. Adapted from Winterbottom (2000). (b) Channel change of the River Clyde at its confluence with the River Medwin, showing downstream migration of meanders; $400 \mathrm{~m}$ above the confluence, the neck of a meander was cut through between 1858 and 1909 . Adapted from Brazier et al. (1993).

$102 \times 74 \mathrm{~mm}(600 \times 600$ DPI $)$ 


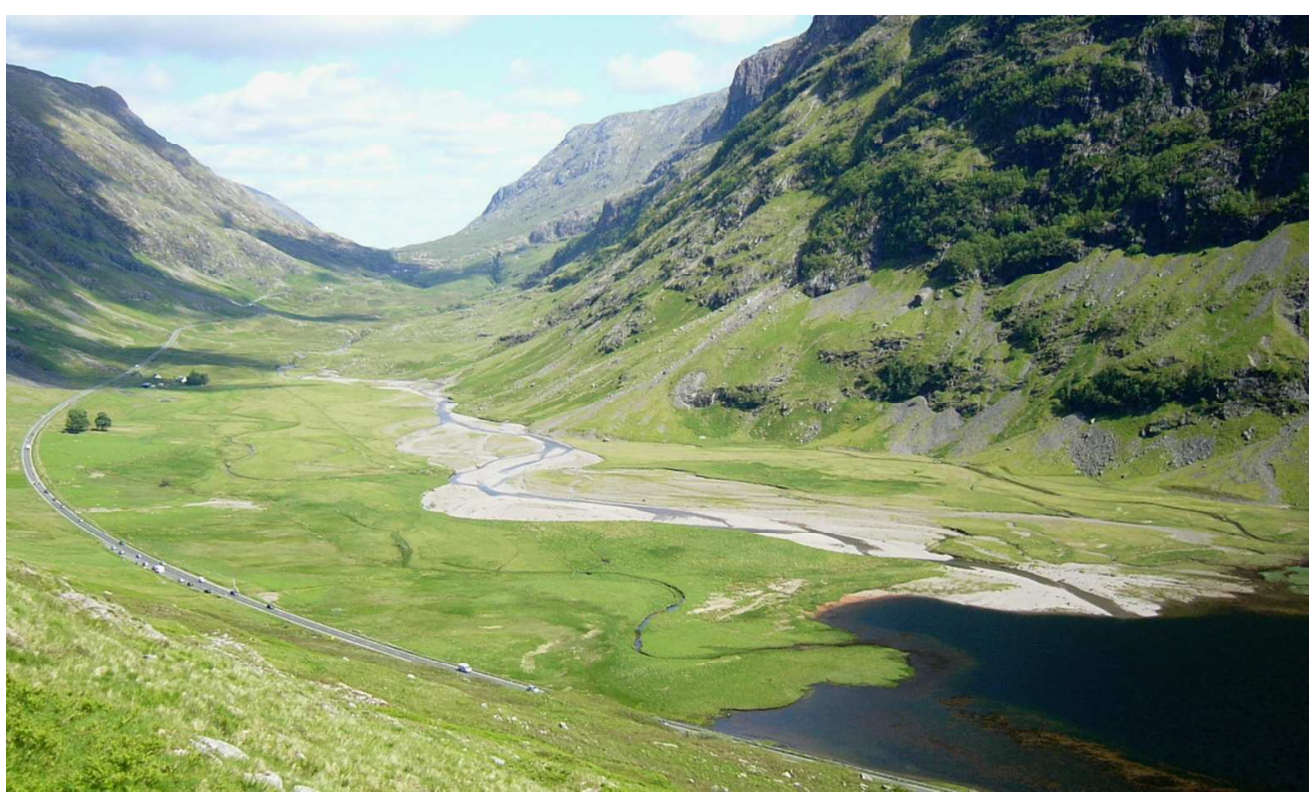

Figure 27 The River Coe above Loch Achtriochan, a typical wandering gravel-bed river, photographed in June 2005. The palaeochannel nearest the road was active before 1875 . The main channel switched to the far side of the floodplain before 1887 and remained there until after 1962, before switching to its 2005 position sometime before 1988 (McEwen 1994).

$643 \times 383 \mathrm{~mm}(72 \times 72 \mathrm{DPI})$ 